UNIVERSIDADE DE SÃO PAULO

FACULDADE DE FILOSOFIA, LETRAS E CIÊNCIAS HUMANAS

DEPARTAMENTO DE CIÊNCIA POLÍTICA

PROGRAMA DE PÓS-GRADUAÇÃO EM CIÊNCIA POLÍTICA

Ingrid Cyfer Chambouleyron

Orientador: Prof. Dr. Cícero Araújo

A TENSÃO ENTRE MODERNDIADE E PÓS-MODERNIDADE NA CRÍTICA À EXCLUSÃO NO FEMINISMO

São Paulo, 2009 
UNIVERSIDADE DE SÃO PAULO

FACULDADE DE FILOSOFIA, LETRAS E CIÊNCIAS HUMANAS

DEPARTAMENTO DE CIÊNCIA POLÍTICA

PROGRAMA DE PÓS-GRADUAÇÃO EM CIÊNCIA POLÍTICA

\section{A TENSÃO ENTRE MODERNDIADE E PÓS-MODERNIDADE NA CRÍTICA À EXCLUSÃO NO FEMINISMO}

Ingrid Cyfer Chambouleyron

Tese apresentada ao Departamento de Ciência Política da Faculdade de Filosofia, Letras e Ciências Humanas da Universidade de São Paulo para obtenção do título de Doutora em Ciência Política.

Orientador: Prof. Dr. Cícero Araújo

São Paulo, 2009 
Caminante son tus huellas el camino y nada más Al andar se hace el camino $Y$ al volver la vista atrás Se ve la senda, que nunca a se volver a pisar

Caminante no hay camino, se hace el camino al andar

Antonio Machado 
A meu filho,

Thiago Cyfer Goularte

minha razão pra caminhar

AGRADECIMENTOS

Agradeço a Capes pelo financiamento do doutorado, inclusive do estágio na New School for Social Research. Agradeço a meu orientador, Prof. Dr. Cícero Araújo, pelo apoio e diálogo aberto. Agradeço também a Prof. Nancy Fraser, minha orientadora 
durante o estágio no exterior, pela oportunidade de discutir suas próprias idéias e pelas orientações bibliográficas..

Gostaria também de agradecer a algumas pessoas queridas que se tornaram ainda mais importantes e especiais durante o doutorado. Às minhas amigas "salva-vidas", Daniela Ikawa, Fernanda Kapritchof, Lilian Furquim e Rossana Rocha Reis. Nos momentos de maior escuridão, foram elas que me trouxeram à tona de novo.

A Verônica Gusmão, pelo seu carinho e generosidade. A Matias Chambouleyron, por dez anos de companheirismo absoluto. A meus irmãos, Flávia e Ricardo. Apesar da distância, souberam ser parceiros e cúmplices. Cada um a seu modo, foi irmão no sentido mais profundo do termo.

Também tenho muito a agradecer a Raphael Neves. Sua recepção em Nova York, as discussões e as dicas para me adaptar mais rapidamente ao cotidiano da cidade e da universidade amenizaram a angústia de ser estrangeira. Mas agradeço, sobretudo, por ter tornado minha passagem por Nova York intensa, encantadora e inesquecível.

A minha mãe, Renina Cyfer, devo um agradecimento especial. Sua participação na tese foi tão fundamental que sem ela a tese não teria existido. Além do aconchego maternal, soube ser amiga, companheira e uma interlocutora competente e interessada em momentos cruciais.

A meu filho, Thiago Cyfer Goularte, por 20 anos de amor de incondicional. Por sua maturidade e serenidade em momentos críticos. Por ter me oferecido carinho no lugar de cobranças em um período de muitas ausências e turbulências. Enfim, agradeço por esse amor leve e maduro que poucos têm a sorte de receber de seu próprio filho.

Agradeço, enfim, a meu pai, Mário Cyfer. Meu eterno "muso inspirador”. Sempre com muitas saudades. 


\section{Resumo}

O objetivo deste trabalho é analisar o projeto de Nancy Fraser de pacificar a chamada "guerra de paradigmas" na teoria feminista, ou seja, o confronto entre teorias feministas pós-modernas e modernas. Essa análise é feita a partir do debate entre Judith Butler, Seyla Benhabib e Nancy Fraser acerca dos problemas teóricos que emergem das exclusões no movimento feminista, ou seja, da dificuldade de o movimento representar as várias formas de viver a condição feminina, levando em conta as intersecções entre a identidade de gênero, racial, de classe, etc.

A intenção de Nancy Fraser é combinar a concepção de sujeito moderno e pósmoderno a fim de somar a desconstrução do sujeito, ou seja, a desnaturalização da identidade feminina com as concepções de igualdade e autonomia que estão presentes no argumento de Benhabib. Essa discussão remete a três tensões conceituais: autonomia e contextualização do sujeito; identidade e reconhecimento da diferença e igualdade e pluralidade.

Por fim, concluo que a conciliação entre modernidade e pós-modernidade é problemática porque a concepção de sujeito pós-moderno apresenta desafios teóricos profundos a uma autonomia suficientemente forte para justificar a crítica social. No entanto, isso não significa necessariamente ter de escolher entre poder e autonomia, entre sujeito abstrato e determinado pelo meio. Na concepção de self narrativo de Benhabib, que ela concebe sob a influência do "modernismo relutante de Hannah Arendt", encontra-se um modelo de conciliação de poder e autonomia mais promissor para vencer a exclusão no feminismo sem abandonar a identidade coletiva no movimento feminsita. 


\begin{abstract}
The subject of this thesis is Nancy Fraser's attempt to overcome the tension between post-modernism and modernism in the feminist political theory, known as "the paradigm war". This attempt is analysed though her debate with Judith Butler and Seyla Benhabib about the theoretical consequences of dealing with the problem of exclusion within the feminist movement.

Nancy Fraser intends to combine Judith Butler's conception of the subject with Benhabib's conception of equality. For her, this is the only way to integrate power and autonomy in feminist political theory. This discussion leads to three theoretical tensions: contextualization of the subject and autonomy; identity and recognition of difference, and equality and plurality.

My conclusion is that this combination is not possible because the post modern subjet challenges any conception of autonomy that is strong enough to explain and motivate social criticsm. Nevertheless, in Benhabib's conception of "self narrative", inspired in the "reluctant modernism of Hannah Arendt", we can find a theoretical model that is more adequate to fight the exclusion in feminist movement without abandoning its colletive identity.
\end{abstract}




\section{Índice}

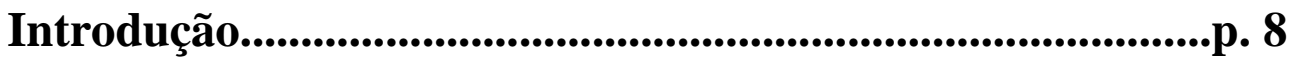

\section{Capítulo I}

Feminismo Moderno e Pós-moderno: uma falsa antítese ?- ............p. 15

\section{Capítulo II}

Contextualização do Sujeito e Autonomia. p. 43

\section{Capítulo III}

Reconhecimento e Resistência........................................... p. 66

\section{Capítulo IV:}

Identidade e Diferença.........................................................P. 96

À guisa de Conclusão..........................................................p. 123

Bibliografia..........................................................................................p. 136 


\section{Introdução}

"Convém dizer-lhes que, desde que ficara só, não olhara uma só vez para o espelho. Não era abstenção deliberada, não tinha motivo; era um impulso inconsciente, um receio de achar-me um e dois, ao mesmo tempo, naquela casa solitária; e se tal explicação é verdadeira, nada prova melhor a contradição humana, porque no fim de oito dias deu-me na veneta de olhar para o espelho com o fim justamente de achar-me dois. Olhei e recuei. O próprio vidro parecia conjurado com o resto do universo; não me estampou a figura nítida e inteira, mas vaga, esfumada, difusa, sombra de sombra. A realidade das leis físicas não permite negar que o espelho reproduziu-me textualmente, com os mesmos contornos e feições; assim devia ter sido. Mas tal não foi a minha sensação.

\section{(...)}

- Lembrou-me vestir a farda de alferes. Vesti-a, aprontei-me de todo; e, como estava defronte do espelho, levantei os olhos, e... não lhes digo nada; o vidro reproduziu então a figura integral; nenhuma linha de menos, nenhum contorno diverso; era eu mesmo, o alferes, que achava, enfim, a alma exterior. Essa alma ausente com a dona do sítio, dispersa e fugida com os escravos, ei-la recolhida no espelho."

Machado de Assis, "O espelho: esboço de uma nova teoria da alma humana"

Na solidão, o alferes perdeu a identidade. Ele que temia olhar para o espelho com medo de "achar-se dois"; ficou perplexo quando não pôde encontrar "um". Sem sua tia e sem os escravos que, a todo momento, lhe lembravam quem era, ele não pôde enxergar seu próprio reflexo no espelho. Somente recorrendo a um símbolo de sua posição social, a farda de alferes, é que sua imagem se recompôs.

O conto "O Espelho" percorre o tema da subjetividade sugerindo que há algo, senão tudo, em nosso "eu" que não nasce e nem sobrevive apenas dentro de nós. Os 
"outros" cumprem uma função indispensável na formação de nossa auto-imagem. São eles que nos atribuem nossos papéis sociais. E são esses papéis, por sua vez, que formam nossa identidade. Por isso, para a personagem do conto, ser "um" era o equivalente a ser um alferes. E para ser um alferes, era preciso ser tratado como tal. Sozinho, diante do espelho mudo, a visão de seu corpo não era suficiente para lhe dar qualquer imagem. Foi preciso o reflexo da farda para que o espelho lhe dissesse quem era.

Atribuir ao mundo exterior um papel tão relevante na constituição do "eu", desafia a idéia de que nossa identidade está formada antes de começarmos a interagir com nosso meio. Esse desafio não é novo, nem na literatura e nem nas reflexões teóricas. Na teoria política, na filosofia e na psicanálise esse tema se traduz na crítica ao sujeito moderno.

O sujeito moderno é kantiano. A característica que o define é a racionalidade. A razão está com o sujeito antes de seu ingresso nas relações sociais. As relações sociais irão agregar especificidade a cada indivíduo, mas o sentido mais profundo de "ser humano", a racionalidade, permanece inabalável.

A razão, enfim, é o fundamento da universalidade da natureza humana. Somos todos iguais, porque somos racionais. E por sermos racionais, somos também todos livres. A razão nos permite conhecer. O conhecimento, por sua vez, permite-nos julgar e gerir nossa vida de modo autônomo.

A universalidade moderna é abstrata. Não importa qual seja o contexto, todos os seres humanos terão sempre o potencial de se liberar das amarras que a sociedade lhes impõe. Sua capacidade crítica, de avaliar e reagir às desigualdades reais está fundada no "fato da razão", que é permanente e universal.

A igualdade e a liberdade moderna têm a vantagem de não condicionar a nada mais do que a razão, ou seja, a algo que todos temos, o respeito e a dignidade. É um modo de questionar hierarquias sociais e culturais que ameaçam o valor do ser humano como fim em si mesmo.

No entanto, a cegueira do sujeito moderno às nossas vinculações sociais e históricas é muitas vezes acusada de funcionar como um instrumento de dominação, ou seja, como um modo de esconder, atrás de uma concepção de natureza humana universal, as desigualdades sociais, culturais e históricas. 
Michel Foucault é um dos autores dessas acusações. Mas sua preocupação vai além de enfatizar que nossa capacidade crítica é afetada pela posição social que ocupamos. Para ele, o meio não é apenas um fator que influi no processo de nossa constituição; ele é o material do qual somos formados. Nós somos o "produto" de nosso meio.

Foucault quase inverte a hierarquia na relação entre o contexto e o sujeito. Enquanto o sujeito moderno é senhor de si e de seu meio, o sujeito foucaultiano é moldado pelas relações de poder que organizam cada sociedade. Isso significa que Foucault substitui a autonomia calcada na racionalidade pelo determinismo social?

A inversão que Foucault propõe não é total. Grande parte de seu esforço intelectual ao longo de sua vida foi explicar que o sujeito produzido pelo poder não é determinado por ele. Ou seja, foi dizer que, mesmo numa relação tão forte entre sujeito e contexto, há espaço para a autonomia.

No entanto, seu argumento não soa convincente para muitos. Foucault é, freqüentemente, acusado de ter decretado a morte do sujeito e, assim, destruído a capacidade crítica e o potencial transformador da ação política. Se somos todos "produto" de nosso meio, como podemos avaliá-lo, criticá-lo e modificá-lo?

O movimento feminista conferiu um espaço privilegiado para essa questão desde meados da década de 1980. Denúncias de exclusão dentro do feminismo alertaram para o problema de sua representatividade. Mulheres que se sentiam marginalizadas pelo próprio movimento acusaram-no de exprimir apenas as vozes das mulheres da elite racial e social. As primeiras a levantarem essa questão foram as negras norteamericanas, mas logo esse tema invadiu os movimentos feministas pelo mundo todo, inclusive no Brasil.

Desde então, a teoria feminista estendeu a crítica ao "sujeito moderno universal" à "mulher universal". Isso significa que mesmo quando a universalidade já foi questionada pela contextualização do gênero, ou seja, quando já foram consideradas as particularidades das condições masculina e feminina, a universalidade continua excludente. Tanto quanto o "homem universal", a "mulher universal" também é uma falácia. Nesse caso, uma falácia que serve aos interesses das mulheres socialmente privilegiadas. 
A ênfase na contextualização da "mulher" tornou-se um dos tópicos centrais da teoria feminista a partir da década de 1990. Além da condição social, histórica e racial, o feminismo acrescentou a contextualização pela corporificação (embodiness). Na identidade de gênero, o corpo cumpre um papel fundamental na atribuição de papéis. Afinal, a fundamentação natural da distribuição de tarefas e oportunidades de acordo com o gênero é em grande parte justificada por diferenças biológicas. Por isso, contextualizar a categoria mulher implica considerar a relação entre as diferenças inscritas no corpo e as desigualdades raciais, de classe e políticas.

A discussão sobre o processo de construção do sujeito tem relação direta com a ação política. O que está em jogo no tema da subjetividade é a capacidade crítica do sujeito, sua capacidade de inovar, de transformar a si mesmo e a sua realidade. Para a teoria política feminista, esse tema envolve três problemas centrais. Em primeiro lugar, se a "mulher" é uma construção social, como ela pode se rebelar contra as desigualdades de gênero de sua sociedade?

Em segundo lugar: conforme seja o espaço social no qual o sujeito é constituído, o modo como o reconhecimento social será atribuído será distinto. Se o espaço social for inevitavelmente assimétrico, então não haverá a possibilidade de reconhecimento recíproco. Para o feminismo, isso significa que a identidade de um grupo de mulheres implica a exclusão de outro grupo. A exclusão no feminismo torna-se, assim, um problema insuperável. Mas será preciso escolher entre o reconhecimento recíproco, que retoma a igualdade abstrata da modernidade, e a inevitabilidade da exclusão no feminismo?

A saída desse impasse exige um reconhecimento recíproco que parta de uma concepção de igualdade que incorpore as diferenças entre as mulheres. É preciso, portanto, explorar a possibilidade de um espaço social que admita, ao menos como hipótese, a simetria entre os seus participantes, mas sem negligenciar o papel que o poder cumpre nas interações humanas.

As respostas dadas a esses problemas delimitaram a fronteira entre dois grandes campos epistemológicos na teoria feminista, cujo confronto ficou conhecido como "guerra de paradigmas". De um lado, está o feminismo pós-moderno, do qual Judith 
Butler é uma das referências mais importantes. De outro, o feminismo moderno. Aqui, uma das principais autoras é Seyla Benhabib.

Judith Butler e Seyla Benhabib iniciaram um acirrado debate em 1991, no qual cada uma das autoras delimitou as margens do feminismo pós-moderno e moderno, respectivamente. Essa discussão foi mediada por Nancy Fraser, para quem as antíteses entre Butler e Benhabib são apenas aparentes. Para ela, o paradigma moderno e pósmoderno são complementares. Para que o feminismo seja ao mesmo tempo capaz de descrever as desigualdades de gênero e de superá-las, é preciso somar o processo de subjetificação de Butler com a concepção de igualdade de gênero de Benhabib.

Para Judith Butler, a principal tarefa do feminismo é reconstruir o processo de formação das identidades de gênero. A uniformização da categoria "mulher" precisa ser "desconstruída”, ou seja, é preciso refazer o trajeto da construção da "mulher universal" a fim de mostrar que sua universalidade e naturalidade são uma farsa. Recuperando as tensões e os jogos de poder no qual a "mulher" foi construída, é possível revelar os interesses que a "mulher universal" representa.

Benhabib, por sua vez, acredita que a desconstrução do sujeito não é o caminho adequado para enfrentar a exclusão no feminismo. Ela afirma que esse método implica a destruição do sujeito e de sua autonomia, estendendo a Butler a crítica que é, frequentemente, dirigida a Foucault.

Enfim, a principal preocupação de Butler é o papel que o poder cumpre na constituição da identidade no feminismo, enquanto o foco de Benhabib é a transformação das relações de poder que definem as desigualdades de gênero. Fraser, por sua vez, quer combinar poder e autonomia na teoria feminista misturando ingredientes pós-modernos com modernos. Em Butler e em Benhabib, ela enxerga o caminho para essa integração.

O objetivo deste trabalho é analisar o projeto de Nancy Fraser de pacificar a "guerra de paradigmas". Essa tentativa nada mais é do que um modo de reunir igualdade e diferença, poder e autonomia, numa teoria feminista capaz de descrever a desigualdade de gênero em cada contexto social e emancipar as mulheres dessas desigualdades. 
O primeiro capítulo apresenta o debate inicial entre Butler, Benhabib e Fraser, a fim de sistematizar os argumentos que estão em conflito na guerra de paradigmas. No capítulo 2, são analisados os processos de subjetificação em Butler e em Benhabib, de modo a identificar os pontos comuns e divergentes entre elas acerca das consequiências que o processo de construção social do sujeito produz no potencial crítico do movimento feminista.

O terceiro capítulo trata do reconhecimento social. Aqui são discutidas as concepções de reconhecimento em Butler, Benhabib e Fraser para explorar a possibilidade de o espaço social abarcar um reconhecimento plural. O objetivo aqui é, enfim, investigar a possibilidade de a identidade coletiva funcionar para reunir, sem sufocar, as diferenças entre as mulheres.

Finalmente, o quarto capítulo trata da igualdade que está por trás da concepção de reconhecimento mútuo. O foco está nas idéias de Benhabib e Fraser, que buscam em Habermas a concepção de universalismo procedimental, mas que imprimem modificações relevantes nesse conceito. Essas modificações as afastam não somente de Habermas, mas também uma da outra.

A escolha da discussão entre Judith Butler, Seyla Benhabib e Nancy Fraser como objeto deste trabalho deve-se a três razões. Em primeiro lugar, porque aborda os problemas teóricos que decorrem da dificuldade de o feminismo lidar com os conflitos de interesses entre as próprias mulheres. Um tema que é atual e relevante para o movimento feminista em qualquer parte do mundo, especialmente em sociedades com desigualdades sociais profundas, como a brasileira. Em segundo lugar, porque foi o debate entre essas autoras que definiu os pólos da guerra de paradigmas. Finalmente, porque as três autoras reconhecem os problemas decorrentes da adoção do sujeito moderno. Todas são sensíveis às denúncias de exclusão no movimento feminista. Não se trata, portanto, de colocar em discussão posições extremas e incomunicáveis entre si. São posições que compartilham a mesma preocupação acerca da exclusão nos movimentos sociais e que, em alguma medida, estão preocupadas em enfrentar a tensão entre poder e autonomia. Por isso, a promessa de Fraser de vencer essa tensão no feminismo não é apenas relevante. É também, pelo menos a princípio, plausível. 


\section{Capítulo I: Feminismo moderno e pós-moderno: uma falsa antítese?}

O que é uma mulher $\mathrm{O}$ movimento feminista por muito tempo considerou essa resposta óbvia. Mas ao longo de sua história, o movimento feminista foi progressivamente sendo desafiado a lidar com o problema do conflitos de interesses e as assimetrias de poder entre as próprias mulheres. A representatividade da "mulher" no feminismo passou a ser questionada. Quem é essa mulher universal que fala em nome de todasi

A "mulher" do feminismo variou ao longo do tempo. O signficado de ser mulher variou conforme o contexto histórico de cada fase do movimento. Mas em todas as fases, foi sempre a mulher socialmente privilegiada que exprimiu os anseios e as demandas femininas.

Nas primeira fase do movimento feminista, "a primeira onda", a demanda feminista por excelência foi o direito à participação política. O sufrágio universal destacou-se como o principla tema do feminismo. Esse período inciou-se no séc XVII e se prolongou até o início do século XX nos Estados Unidos e no Reino Unido. ${ }^{1}$.

Os marcos finais da "primeira onda" foram o Representation of the People Act de 1918, no Reino Unido, que garantiu o direito ao voto às mulheres acima de 30 anos que possuíssem propriedade ${ }^{2}$, e a Emenda 19 à Constituição Americana, que assegurou o direito ao voto às mulheres em todos os Estados da federação.

A chamada "segunda onda" do feminismo, por sua vez, teve início no segundo pós guerra, acrescentando à luta contra a desigualdade de participação política, a crítica à desigualdade social e cultural. As diversas teorias que emergiram dessa etapa do feminismo convergem para o slogan "o pessoal é político", considerado sinônimo da segunda onda. O sentido dessa expressão é problematizar a dicotomia liberal

\footnotetext{
${ }^{1}$ Brysson, Valérie. Feminist Political Theory.London: Macmillan Press, 1992, pp. 36 e ss.

${ }^{2}$ Em 1928, esse ato é alterado de modo a estender o direito ao voto a todas as mulheres acima de 18 anos. Ver Amar, Akhilreed "How women won the vote" in The Wilson Quartely, 29, n.3. Summer, 2005, pp. 30 e ss.
} 
público/privado ${ }^{3}$, reconhecendo que a igualdade na esfera pública está condicionada pela igualdade na esfera doméstica, uma vez que é nesta última que parte das condições de acesso à vida política será definida. Além disso, com o questionamento da divisão estanque entre o público e o privado pretendeu-se desmistificar os pressupostos de harmonia espontânea nas relações familiares e sujeitá-las a princípios de justiça.

Os trabalhos clássicos do feminismo da segunda onda são "O segundo sexo" de Simone de Beauvoir (1949), “A mística feminina” de Betty Friedan (1963) e “ O tráfico nas mulheres: notas sobre a economia política do sexo" de Gayle Rubin (1975)

Simone de Beauvoir criou o conceito de "corpo como situação" para sustentar a idéia de que a existência do sujeito não coincide com seu nascimento, mas é o resultado da negociação de seu projeto individual com as condições que seu meio oferece para realizá-lo. O sujeito é resultado dessa relação de influências recíprocas entre o "eu" e seu "meio". Assim sendo, ser mulher não é algo previamente definido pela natureza, mas sim uma condição determinada pela relação dialética do sujeito com os significados que a cultura atribui àquilo que considera a essência do feminino. É nesse sentido que Beauvoir afirma que "não se nasce mulher, torna-se mulher"4.

O trabalho de Betty Friedman esteve centrado na inserção da mulher no espaço doméstico. Sua questão é a diluição da identidade feminina na família, a ponto de tornar o casamento e a criação dos filhos a condição da existência da mulher. $\mathrm{O}$ direito a trabalhar fora de casa e de traçar objetivos que ultrapassem os limites da esfera doméstica são seus tópicos principais ${ }^{5}$.

Gayle Rubin, por sua vez, cunhou o vocabulário que foi incorporado por todas as teorias feministas desde então. Rubin criou o sistema sexo/gênero, segundo o qual o sexo corresponde ao aspecto biológico do corpo e o gênero, ao significado que a cultura lhe atribui.

\footnotetext{
${ }^{3}$ Ver Pateman, Carole. "The public/private dichotomy" in Pateman. The disorder of women. Standford University Press, pp. 118 e ss.

${ }^{4}$ Beauvoir, Simone. The Second Sex. New York, London, Toronto: Bantam Books, 1970, pp. 400 e ss. Ver também Moi, Toril. "What is a woman? Sex, gender, and the body in feminist Theory". In What is a woman? (New York, Oxford University Press, 1999), pp 37 e ss.

${ }^{5}$ Idem, p.23
} 
O interesse de Rubin não é analisar o sexo, mas o gênero. O sexo é imutável, natural, mas é a matéria prima para a produção do gênero. $O$ fato de a mulher engravidar e o homem não, por exemplo, é uma diferença determinada pela natureza, sobre a qual não faz sentido fazer juízos de valor. No entanto, essa diferença poderá se degenerar em desigualdade social dependendo do modo como a sociedade a incorporar. São, enfim, as implicações do processo de distribuições de papéis sociais em razão do sexo que são opressivas. Por isso, Rubin sustenta que a emancipação da mulher implica a sua emancipação do gênero. Uma sociedade igualitária, portanto, é uma sociedade sem gênero ${ }^{6}$.

Apesar das divergências marcantes entre as teorias feministas da primeira e a segunda onda, elas compartilham o mesmo lema: a igualdade. Cada uma delas propõe uma concepção de igualdade de gênero em torno da qual o feminismo se mobiliza ${ }^{7}$.

No entanto, em meados da década de 80 , o movimento feminista passou a ser acusado de ser elitista e excludente em função de sua ênfase na igualdade. As mulheres que não se viam representadas pelo movimento acusavam-no de ter silenciado vozes que são marginalizadas por outras razões além do gênero e que, por isso, têm demandas distintas e muitas vezes conflituosas com as das mulheres que lideravam o movimento ${ }^{8}$. Enfim, o feminismo da segunda onda foi acusado de negligenciar as diversas ramificações e os conflitos de interesses entre as próprias mulheres em nome de uma unidade para a representação política do feminismo. Nessa interpretação, Beauvoir, Friedman e Rubin analisaram a condição feminina sob a ótica da mulher ocidental, branca e de classe média.Essa tensão no movimento feminista se iniciou nos Estados Unidos, impulsionada, sobretudo, pelas mulheres negras e logo repercutiu em outras partes do mundo.

No Brasil, o movimento feminista eclodiu na década de 1970. Juntaram-se circunstâncias internacionais ao contexto social e político do país nesse período. No plano internacional, houve a declaração da ONU do ano internacional da mulher, em

\footnotetext{
${ }^{6}$ Idem.

${ }^{7}$ A segunda onda não acabou, não foi superada pela terceira. Todos os debates que partem do slogan "o pessoal é político", ou seja, que discutem a dicotomia público/privado, estão sob a influência de seus pressupostos. Martha Nussbaum, Susan Okin e Carole Pateman são exemplos de autoras contemporâneas que se inserem nesse grupo.

${ }^{8}$ Ver Céli Pinto
} 
1975. No contexto nacional, a participação das mulheres na resistência contra a ditadura foi o principal impulso para o movimento. A presença feminina na militância armada confrontava ao mesmo tempo a ordem política, como também as regras comportamentais destinadas às mulheres. Uma guerrilheira não era apenas uma afronta à ditadura militar, era também uma afronta ao papel social destinado às mulheres 9 .

A transgressão da condição feminina, porém, encontrava obstáculos dentro da própria militância de esquerda. A convergência entre homens e mulheres na luta contra a ditadura não se estendia à luta contra as desigualdades de gênero. No entanto, a experiência do exílio colocou essas mulheres em contato com o efervescente feminismo europeu, em particular o francês, fortemente influenciado pelo pensamento de Simone de Beuavoir e da feminista marxista Alexandra Kollontai. Assim, o feminismo brasileiro articulou as reivindicações políticas da esquerda brasileira com a questão da subjetividade, incluindo o campo da psicanálise na reflexão sobre a condição feminina ${ }^{10}$.

O processo de abertura política contribuiu para a ênfase das especificidades das demandas feministas. As questões de gênero foram tendo destaque à medida que as demandas de políticas públicas dirigidas às mulheres ganharam mais espaço e voz. No entanto, com o declínio da ditadura, vieram à tona as divergências entre as mulheres do movimento, que estiveram contidas pelo poder aglutinador da oposição ao regime militar $^{11}$.

A partir de então, o movimento feminista brasileiro ramificou-se signficativamente. A proliferação das ONGs no Brasil contribuiu para dar maior especificidade às demandas dos diferentes grupos de mulheres e a dirigir essas demandas a reformas institucionais ${ }^{12}$.

A tendência à especialização evolui juntamente com a da trasnacionalização. Muitas ONGs, financiadas por agentes financeiros internacionais, incorporaram à sua agenda reivindicações originadas fora do Brasil. A introdução da questão racial no feminismo brasileiro se deveu em grande parte a esse tipo de intercâmbio. Nesse caso, a

\footnotetext{
${ }^{9}$ Sarti, Cynthia. "O feminismo brasileiro desde os anos 1979: revisitando uma trajetória" in Revista Estudos Feministas, v. 12, n. 2. Florianópolis maio-ago 2004, p. 3

${ }^{10}$ Idem.

${ }^{11}$ Idem, p. 4
} 
influência veio principalmente dos Estados Unidos, onde a discriminação racial teve e tem um papel importante na retórica da diferença no movimento feminista. Assim, o feminismo brasileiro, que nasceu da articulação de questões de classe, de participação política e da subjetividade, introduz a partir da década de 80 a dimensão racial da discriminação de gênero. A fragmentação acentua-se ainda mais ${ }^{13}$..

No Brasil, as feministas negras ressaltaram o entrelaçamento entre a exclusão racial e a desigualdade social. Argumentaram que a emancipação da mulher no país somente foi possível pela transferência das atividades e das responsabilidades historicamente tidas como femininas para as mulheres de classes menos favorecidas. Sem políticas públicas para promover a repartição social das tarefas "femininas", essas tarefas foram transferidas para as empregadas domésticas e babás; quas sempre negras, que continuaram sem ter a quem transferir ou com quem repartir essas responsabilidades ${ }^{14}$.

O problema da exclusão no feminismo torna-se, assim, um tópico central do movimento também no Brasil. Apesar das particularidades da evolução do feminismo no Brasil, ele foi progressivamente caminhando para a agenda feminista internacional, muito influenciada pelo movimento norte-americano; embora as diferenças entre as mulheres no Brasil tivessem sempre levado em conta as particularidades do contexto brasileiro. $^{15}$.

O problema da exclusão no feminismo foi captado pela academia por Julia Kristeva e Lucy Irigaray, que analisam o tema do ponto de vista da teoria psicanalítica, por Chantal Mouffe, Joan Scott, Jane Flax entre outras na teoria política e social. Mas, sem dúvida, o mais influente desses trabalhos é o de Judith Butler, cuja importância para o feminismo de hoje tem sido comparada à que Beauvoir teve na segunda metade do século $\mathrm{XX}^{16}$.

A publicação de "Gender Trouble: Feminism and the Subversion of Identity" de Judith Butler foi responsável pelo que se pode chamar de uma "virada pós-moderna na

\footnotetext{
12 Idem.

${ }^{13}$ Sobre isso ver Côrrea, Mariza. "Do feminismo aos estudos de gênero no Brasul: um exemplo pessoal” in Dossiê: Feminismo em questão, questões do Feminismo. Cadernos Pagu (16) 2001, PP. 13-30.
} 
teoria feminista". A principal tese desse livro é a de que os conflitos no interior do movimento decorrem do fato de o feminismo ter sido moldado a partir de uma identidade feminina universal, que define o sujeito legitimado a representar os interesses de todas as mulheres.

Para Bulter, a desmistificação desse universal é a principal tarefa do feminismo, pois é desse modo que se trazem à tona os conflitos que estiveram presentes na construção da categoria "mulher”, permitindo que a representação política das mulheres permaneça permeável às várias formas de viver a condição feminina. Seu argumento é o de que a definição de uma identidade, qualquer que seja ela, será reducionista e excludente, uma vez que não há características humanas suficientemente estáveis e abrangentes. Por isso, as políticas de identidades expressam reivindicações de apenas uma parcela do grupo que representa. É essa parcela que define quem ocupa a posição privilegiada nas relações de poder que constituíram a identidade de gênero ${ }^{17}$.

A principal tarefa de um feminismo inclusivo, portanto, é a desconstrução da identidade feminina, a fim de revelar a contingência e as descontinuidades no processo de sua construção histórica. É preciso abdicar da busca da estrutura universal da dominação da mulher e reconhecer que essa universalidade é ilusória não apenas quando se refere ao fundamento da dominação, mas também à própria identidade do dominado. A tese de Butler, assim, deslocou o debate teórico sobre o feminismo para a questão da diferença, que é o tema característico da terceira onda do feminismo.

A recepção de "Gender Trouble" foi bastante controversa. Ganhou simpatizantes fervorosos e críticas ferozes. Mas entre todos os intensos debates que gerou, o de maior repercussão foi travado entre Bulter, Seyla Benhabib e Nancy Fraser na revista Praxis internacional em $1991^{18}$, que ainda hoje é uma referência na teoria política feminista.

Os tópicos principais dessa discussão referem-se ao problema da disputa entre igualdade e diferença como lema do feminismo. Butler assumidamente privilegia o tema da diferença, enquanto Benhabib e Fraser procuram lidar com os problemas levantados por Butler preservando a igualdade como valor indispensável para que o

\footnotetext{
${ }^{16}$ Allen, A. The politics of our selves: power, autonomy and gender in contemporary critical theory. Columbia University Press, 2008, p 3.

${ }^{17}$ Butler,Judith. Gender ; trouble: feminism and the subversion of identity. New York and London: Routledge Classics, 2007, p. 10
} 
feminismo não comprometa seu caráter crítico. A tensão entre igualdade e diferença remete à conciliação entre as assimetrias de poder entre as mulheres e um ideal de igualdade de gênero.

A questão da diferença em Butler está diretamente relacionada à sua concepção de sujeito "constituído pelo poder", que herda de Foucault, que traz consequências para sua forma de compreender a autonomia do sujeito e a capacidade de o feminismo funcionar como crítica social.

Seguindo Foucualt, Butler sustenta que as relações de poder não apenas incidem sobre o indivíduo; elas constituem sua identidade. Dessa forma, ela pretende explicitar que a identidade de gênero não é naturalmente dada, mas sim um produto de uma determinada configuração das relações de poder. Assim, para ela, subverter as relações de poder que oprimem mulheres ou homossexuais implica alterar essas relações de modo que a identidade que resulte delas reflita uma configuração de poder distinta.

Seyla Benhabib, por sua vez, sustenta que Butler, ao entender o sujeito como produto do poder, deixa o feminismo sem meios de agir ou de julgar o caráter emancipatório das tranformações sociais. Ela afirma que, assim como Foucault, Butler decretou a morte do sujeito e com ele a morte de sua autonomia. Butler, por sua vez, acusa Benhabib de conceber um sujeito abstrato, fundamentado em um universalismo essencialista.

A posição assumida por Fraser nesse debate foi a de mediar Butler e Benhabib, mostrando que seus argumentos não são incompatíveis entre si e que dessa compatibilidade depende uma teoria crítica feminista capaz de desconstruir a identidade essencializada e excludente sem comprometer a autonomia do sujeito. Ela quer aproveitar a idéia de desconstrução do sujeito de Butler para combater o essencialismo, mas afirma que para tornar o feminismo uma forma de crítica social é necessário reconstruir a identidade do sujeito e retomar uma normatividade que dirija a sua emancipação. Sua preocupação, enfim, é comprometer a crítica feminista com os dois

\footnotetext{
${ }^{18}$-Ver Praxis internatonal, 11.3 (July, 1991).
} 
objetivos das teorias críticas: a descrição da desigualdade e a formulação de um projeto emancipatório $^{19}$.

Para realizá-los, a teoria crítica feminista deve cumprir as seguintes tarefas ${ }^{20}$ : analisar a subordinação (tarefa que tem como foco o poder); criticar essa subordinação, e oferecer indicações para o caminho da transformação social (foco na autonomia) e, finalmente, tem de estudar como o poder estrutura o desejo dos indivíduos de se subordinarem ou de criticarem. Neste caso, o foco está tanto do poder como na autonomia.

Fraser assume que a articulação entre poder e autonomia é uma condição necessária para que a teoria política feminista funcione como crítica social que não seja nem ingênua e metafísica, nem estéril do ponto de vista da formulação de projetos emancipatórios.

Neste capítulo, o objetivo é anunciar o argumento de cada uma dessas autoras, uma vez que as críticas que fazem uma a outra cumprem a função de sistematizar os eixos da divergência entre a perspectiva pós-moderna e moderna na teoria feminista, eixos estes que estruturarão os capítulos seguintes.

\section{1) Judith Butler: gênero performativo e a crítica ao "feminismo como política de identidade"}

"Feminismo pós-moderno" e "Feminismo pós-estruturalista" costumam ser usados como sinônimos. Em parte porque pós-modernismo e pós-estruturalismo compartilham muitos pontos comuns na crítica à modernidade; e, em parte porque o feminismo pósmoderno costuma ser interpretado como uma fusão entre pós-modernismo e pós-

\footnotetext{
${ }^{19}$ Fraser, Nancy. “False antitheses: a response to Seyla Benhabib and Judith Butler" . in Fraser, n. Justice Interruptus: critical reflections on the postsocialist condition. Routledge: New York, 1997. Este artigo foi publicado primeiramente no $\mathrm{n}$. da praxis international citado anteriormente.

${ }^{20}$ Essas tarefas são enumeradas por Amy Allen em Allen, A. The politics of our selves: power, autonomy and gender in contemporary critical theory. Columbia University Press, 2008, p 15.
} 
estruturalismo $^{21}$. No entanto, cada um deles originou-se de tradições filosóficas distintas.

A expressão "pós-modernismo" foi criada por Jean François Lyotard em "A condição pós-moderna". Sua intenção foi fazer uma crítica às teorias que têm a pretensão de identificar a chave explicativa da evolução da história da humanidade. Os principais alvos do autor são o iluminismo e o marxismo. Para Lyotard ambos se apresentam como condição de validade dos demais discursos; sem jamais problematizar a sua própria legitimidade ${ }^{22}$.

Lyotard considera que as narrativas de justificação direcionadas a situações específicas devem substituir normas gerais formuladas pela "Filosofia da Ciência". Ao invés de a validade da tese científica ser justificada com base em normas gerais, ela tem de ser justificada por regras formuladas pelo próprio cientista quando engajado na produção do conhecimento. Enfim, é o sujeito, na situação de participante da construção do conhecimento, que assume a responsabilidade de legitimar as práticas que ele próprio utiliza. A conseqüência disso é o abandono do sujeito cognoscente imparcial da modernidade e a construção de um sujeito comprometido com a validação daquilo que apresenta como verdade ${ }^{23}$.

O pós-estruturalismo, por sua vez, sustenta que o estudo da estrutura do discurso é ele próprio culturalmente condicionado e sujeito a inúmeras interpretações. Aqui a principal referência teórica é Jacques Derrida, o criador do método da "desconstrução". Esse método consiste na releitura de textos filosóficos e literários com o objetivo de identificar os pontos falhos de sua unidade estrutural. Derrida pretende mostrar que aquilo que está por trás do texto não pode jamais ser completamente desvendado, já que sua suposta coerência e sistematicidade pode ser sempre desconstruída. Enfim, no pósestruturalismo, o conhecimento de um objeto pressupõe o entendimento do sistema de conhecimento que foi coordenado para produzir o objeto; o pós-estruturalismo,

\footnotetext{
${ }^{21}$ Mann, Susan A; Huffman, Douglas. "The decentering of the second wave: feminism and the rise of the third wave" in Science and Society. V.69, n.1 (Jan 2005), p.56.

${ }^{22}$ Fraser, N. and Nicholson, Linda. "Social Criticism without Philosophy: an encounter between feminism and postmodernism" in Nicholson, Linda.Feminism-postmodernism. New York and London: Routledge, 1990, pp.23 e 24.

${ }^{23}$ Idem
} 
portanto, pode ser definido como um estudo da forma como o conhecimento foi produzido $^{24}$.

Em Butler, conforme ser verá em seguida, encontram-se tanto pressupostos pósmodernos quanto pós-estruturalistas. No entanto, ela geralmente revela uma preferência pelo termo "pós-estruturalista", pois considera o termo "pós-moderno" um rótulo (moderno) que uniformiza os diversos modos de criticar a modernidade ${ }^{25}$.

O principal trabalho de Butler corresponde ao "Gender Trouble: Feminism and the subversion of identity", cujo impacto no meio intelectual e no movimento foi decisivo para reorientar o discurso feminista a partir da década de 90. Em 1993, ela publicou "Bodies that Matter", uma tentativa de esclarecer as questões mais polêmicas de seu livro anterior. Em 1997, foi publicado o "Excitable Speach: a politics of the performativity" em que ela trava um debate com feministas que confiam na censura estatal para a proibição da degradação pública da imagem da mulher. Seu principal alvo é o argumento de Catherine Mackinnon contra a pornografia ${ }^{26}$.

Em 2004, é reunida uma coletânea sobre o pensamento de Butler denominada "Undoing gender". Aqui há um certo refinamento de seu conceito de performatividade, formulado em seu primeiro livro, ao fazer uma reflexão sobre a condição do hermafrodita ou do que chama de "intersex"27.

Recentemente, Butler começou a orientar seu trabalho em outras direções. Seus últimos escritos têm privilegiado conflitos internacionais e questões de tolerância de um modo geral.Também é possível observar um certo recuo na sua oposição à normatividade à medida que incorpora aspectos da ética de Levinas. Isso fica evidente em seu trabalho “Giving an account of oneself”, de 2005.

Apesar da diversidade de temas e de abordagens nos trabalhos de Butler, a idéia fundamental que ela defendeu em "Gender Trouble" tem persisitido: a de que as identidades são excludentes e que, por isso, o feminismo tem como missão a

\footnotetext{
${ }^{2424}$ Grosz, Elizabeth. "Derrida and Feminism: a remembrance difference" in Vol. 16, n.3 (Fall, 2005), p. 85 .

${ }^{25}$ Butler. "Contingent Foundations"...

${ }^{26}$ Ver Mackinon, C. Toward a Feminist Theory of the State. Harvard University Press, 1989 e Feminism Unmodified: discourses on life and Law. Harvard University Press, 1987.

${ }^{27}$ Butler, Judith. Undoing Gender. New York: Routledge, 2004.
} 
desconstrução da identidade de gênero. É exatamente em torno dessa questão, e de suas conseqüências, que giram seus desacordos com Benhabib e Fraser.

A proposta de Butler é problematizar as identidades de gênero masculina e feminina, procurando desvincular as diferenças anatômicas entre machos e fêmeas da espécie humana e os comportamentos esperados dos indivíduos em razão dessas diferenças. Esses comportamentos, diz a autora, não decorrem da natureza, mas sim de "regras disciplinares" socialmente construídas que definem o conjunto de características que distinguirão o feminino, ou a "regra da feminilidade", do masculino, ou a "regra da masculinidade ${ }^{28}$.

Butler herda a concepção de "regra disciplinar" de Foucault, sua principal influência na formulação de sua concepção de sujeito. No primeiro volume de " $A$ história da sexualidade", Foucault sustenta que a principal marca da modernidade ${ }^{29}$ é o fato de a conduta sexual ter se tornado um tema estrategicamente relevante à medida que a modernidade tornou o crescimento populacional uma questão política. Isso levou a política moderna a ir gradativamente extrapolando seus temas clássicos (como o fundamento do Estado, o modo correto de governar) para incluir também o controle e a classificação do corpo. Essa classificação, por sua vez, está respaldada por outro traço típico da modernidade, a ciência, responsável por estabelecer os critérios para distinguir o comportamento sexual sadio do doentio ${ }^{30}$.

Na modernidade, afirma Foucault, a ciência e o poder se misturou até o ponto de se fundirem. Dessa fusão, resultou o que Foucault denomina "tecnologia disciplinar", que consiste na técnica 'científica' que cria o padrão de comportamento "correto" e o proibido.

Esse padrão ou, como diz Foucault, esse "ideal regulatório", estabelece regras que não apenas incidem sobre o indivíduo, mas que também o constituem ${ }^{31}$. A idéia de Foucault, incorporada por Butler, é a de que é a própria regra "científica" que cria a

\footnotetext{
${ }^{28}$ Butler, J. Gender Trouble.., p.6.

${ }^{29}$ Em Foucault, a modernidade não corresponde a um período histórico precisamente delimintado, com uma data inicial ou final, mas sim a um conjunto de acontecimentos que inclui a formação d capitalismo, do mundo burguês, do Estado e da ciência. Esses são os acontecimentos que teriam constituído a postura do sujeito moderno frente a si mesmo, frente às relações interpessoais, e à sua relação com o objeto de conhecimento. Ver Foucault, M. "What is Enlightnment" in Rabinow, Paul.The Foucault reader, PP. 42 e 43.

${ }^{30}$ Idem, PP.48-49.

${ }^{31}$ Foucault, M. "History of Sexuality" in Rabinow, Paul. Foucault reader, p. 308.
} 
identidade do sujeito. Essa regra, por sua vez, é fruto de um processo histórico marcado pela luta pelo poder, ou seja, pelo poder de dizer o que está de acordo com a ciência. $O$ vencedor (temporário) dessa luta impõe seu critério para classificar os sujeitos, definindo uma regra hegemônica que regula a atribuição de identidades. É nesse sentido que Foucault afirma que o sujeito é produzido pelo poder ${ }^{32}$.

Judith Butler aproveita essa idéia para questionar o caráter científico e natural da “mulher”. Ela afirma que a dicotomia sexo-gênero de Gayle Rubin estabelece a existência de apenas dois gêneros, o masculino e o feminino, e com isso sugere que o processo de construção do gênero é limitado pelo sexo, ou seja, que há características biológicas imutáveis que constituem uma essência (mesmo que seja uma essência mínima) à qual a cultura atribui significados, significados estes que jamais desafia o núcleo duro da identidade de gênero, a biologia ${ }^{33}$.

Segundo Butler, a dicotomia sexo/gênero (ou natureza/cultura) pressupõe uma distinção total entre o mundo interno e o externo que é insustentável. O sexo "natural" é a característica de um corpo cuja delimitação não é afrontada pelo contexto em que está inserido. O resultado disso é a preservação da coerência e da estabilidade de um sujeito cujo gênero é socialmente inteligível ${ }^{34}$, ou seja, cujo gênero exprime a relação causal entre sexo, gênero e desejo por meio da proibição a determinadas condutas. Dito de outro modo: a dicotomia sexo-gênero garante estabilidade e universalidade à identidade de gênero, na medida em que assume a anatomia do corpo como seu fundamento absoluto $^{35}$.

No entanto, diz Butler, são exatamente essas estabilidade e coerência que devem ser questionadas pelo feminismo, uma vez que essas identidades nada mais são do que produto de relações de poder que definem os grupos de interesse que estarão representados pelo movimento feminista e, por oposição, os que estarão excluídos. Para

\footnotetext{
${ }^{32}$ A idéia de que o poder é produtivo se opõe à noção de poder repressivo. O poder em Foucault não é possuído por uns e imposto a outros;por isso, sua reflexão não inclui questões do tipo "quem deve possuir o poder" ou "quais são os limites do poder". Foucault rejeita o modelo repressivo porque acredita que a repressão não é suficiente para garantir a obediência; a represssão é uma medida drástica para aqueles que perderam o poder. A obediência para Foucault requer que o sujeito se envolva ativamente no processo de produção de sua própria subordinação. Idem.

${ }^{33}$ Butler, J. Gender Trouble, p. 12.

${ }^{34}$ Idem, p. 181. Ver também Butler, J.. "Variations on sex and gender: Beauvoir, Wittig and Foucault" in Benhabib, S. e Cornell, Drucilla (ed)Feminism as critique. University of Minnesota Press, 1987, p. 129 e SS.

${ }^{35}$ Butler, J. Gender ; trouble..., p.10
} 
denunciar essa exclusão é preciso questionar a coerência necessária entre sexo, gênero e sexualidade e admitir que nem mesmo as características biológicas dos seres humanos sãom um terreno suficientemente sólido e estável para fundamentar as identidades ${ }^{36}$.

Seguindo Foucault, Butler afirma que o sexo não corresponde a uma superfície politicamente neutra sobre a qual a cultura incide, mas sim a um produto de discursos científicos que exprimem determinados interesses políticos e sociais. A concepção de sexo como um dado natural é um efeito da construção cultural de comportamentos esperados dos sujeitos. Assim, em Butler, a natureza não limita a construção do gênero, como ocorre na dicotomia sexo-gênero, pois tanto sexo quanto o gênero sãom construções sócio-culturais ${ }^{37}$

Se o sexo realmente não vier da natureza, será necessário investigar porque os seres humanos encontram-se divididos em dois sexos "naturais", será preciso compreender porque os sexos feminino e masculino são o padrão, enquanto outros, como o hermafrodita ou os transexuais, são socialmente inapreensíveis; será preciso compreender, enfim, quais são os interesses políticos que estão por trás dessas exclusões. Para isso, diz Butler, será necessário analisar as regras disciplinares que construíram as identidades de gênero ${ }^{38}$. Isto porque,

Tanto o sexo quanto o gênero sãom resultado da tentativa de os sujeitos se adequarem à regra disciplinar, que constrangerá a mulher a se comportar de modo "feminino" e o homem, a agir de modo "masculino". É nesse sentido que Butler afirma que o gênero é performativo, ou seja, que o gênero é constituído por modos de agir associados à feminilidade e à masculinidade ${ }^{39}$.

À medida que o comportamento definido pela regra disciplinar é reproduzido pelos próprios sujeitos, a identidade que é criada por essa performance ganha status de essência interior, criando assim a ilusão de que há uma natureza feminina e masculina que determina ou ao menos influencia as preferências e os comportamentos do homem e

\footnotetext{
${ }^{37}$ Idem.

${ }^{38}$ Idem, p.2

${ }^{39}$ Butler, J. Gender Trouble...
} 
da mulher ${ }^{40}$. Assim, a origem política e discursiva da identidade de gênero é encerrada em um núcleo biológico.

Em Butler, a regra disciplinar fundamental da identidade de gênero é a heteronormatividade, que estabelece a heterossexualidade como princípio regulatório da sexualidade. O desejo sexual do homem pela mulher e vice-versa é o fundamento último da identidade feminina e masculina. A sexualidade, portanto, é a matriz da identidade de gênero porque é no desejo heterossexual em que está a causa primeira das regras da feminilidade e da masculinidade ${ }^{41}$.

Segundo Butler, a heteronormatividade está implícita no sistema sexo-gênero de Gayle Rubin porque ele comporta apenas o binarismo homem-mulher. Esse sistema, embora questione a idéia de que a biologia define a identidade, supõe uma correspondência entre natureza e cultura. Sendo assim, as pessoas que de algum modo rompem essa correspondência sãom relegadas à condição de párias sociais ${ }^{42}$.

Com medo dessa punição, os indivíduos lutam para apagar qualquer traço de ambigüidade em sua sexualidade por meio da reprodução dos comportamentos definidos pela regra hegemônica, comportamentos estes que vão muito além do ato sexual propriamente dito.

Se a identidade é uma construção social, será em público que o sujeito deverá demonstrar sua heterossexualidade. A forma como gesticula, como se senta, a entonação de sua voz, a ênfase na emoção ou na razão; enfim, todos os modos de agir do sujeito em público estarão associados à sua sexualdiade. O homem heterossexual deverá "provar" publicamente seu desejo por mulheres agindo de modo masculino, enquanto a mulher atestará sua heterossexualidade agindo de modo feminino ${ }^{43}$.

O descumprimento da regra disciplinar da masculinidade e da feminilidade colocará a heterossexualidade do sujeito sob suspeita. O preço disso não será apenas a perda da "identidade de mulher heterossexual" ou de "homem heterossexual"; será a perda da identidade "mulher" e da identidade "homem" . Em um sistema em que vigora

\footnotetext{
${ }^{40}$ Butler, J. Bodies that matter, PP.185 e 186.

${ }^{41}$ Butler

42 Butler,

${ }^{4343}$ Butler, Gender Trouble, p.
} 
a regra da heteronormatividade, a conseqüência dessa perda é ser (cientificamente) classificado como um caso patológico ${ }^{44}$.

O único modo de evitar isso é o sujeito conformar seu próprio comportamento à heteronormatividade. Assim, além de oprimido pela regra, o indivíduo é também oprimido por si mesmo, pela sua performance. Tudo isso em nome de seu reconhecimento social ${ }^{45}$. Por isso, diz Butler, a proibição de uma determinada forma de agir não é um inibidor da ação, mas sim aquilo que a impulsiona ${ }^{46}$.

A principal consequência da reiterada reprodução da performance da heternormatividade, são o ocultamento do caráter político da regra disciplinar. De tanto ser repetida em toda parte, ela termina ganhando status de "natural" e, portanto, de "universal". Desse modo, é criada a ilusão da "essência feminina" e da "essência masculina" como determinantes de preferências e comportamentos do homem e da mulher ${ }^{47}$.

Se é a performance da regra da heteronormativadade que cria a ilusão de femininos e masculinos naturais, o locus da desconstrução da identidade "natural" será também a performance do sujeito. Mas, nesse caso, o comportamento do sujeito deverá confundir a correspondência entre desejo, sexo e gênero ao invés de confirmá-la. Por isso, Butler afirma que a forma de resistência feminista paradigmática é a performance da Drag Queen ${ }^{48}$.

As "drags" são subversivas não porque modifiquem a representação do feminino; afinal, elas, ao contrário, reproduzem o feminino de modo completamente estereotipado. No entanto, sua performance da regra da feminilidade é realizada por um corpo anatomicamente masculino. Assim, elas expõem publicamente a possibilidade de dissonância entre sexo, sexualidade e gênero e revelam que a fundamentação da identidade feminina e masculina na natureza humana é uma ficção.

Desmascarada essa farsa, é possível questionar a regra disciplinar hegemônica e as exclusões que determina, pois se o feminino e o masculino não forem uma

\footnotetext{
${ }^{44}$ Butler e Foucault

${ }^{45}$ Colocar butler e também referência a allen

${ }^{46}$ Bulter, Bodies that matter,

${ }^{47}$ Butler, J.Bodies that matter, PP. 185 e 186.

${ }^{48}$ Butlerb
} 
determinação natural (sobre a qual não há nada o que fazer) virão à tona as relações de poder que sustentam a heteronormatividade e com elas emergirá também a possibilidade de os excluídos resistirem à regra e lutarem por reconhecimento social ${ }^{49}$.

\section{b) Seyla Benhabib: feminismo como crítica}

Seyla Benhabib, em artigo denominado "feminism and postmodernism: an uneasy alliance", examina o feminismo pós-moderno e sua compatibilidade com o conteúdo normativo do feminismo ${ }^{50}$. Sua intenção é compreender as razões da aproximação entre pós-modernismo e feminismo e apontar suas dificuldades.

Partindo da sistematização das principais idéias do pós-modernismo feita por Jane Flax no livro "Thinking fragments: Psychoanalysis, Feminism and Postmodernism in the Contemporary West ${ }^{51}$, Benhabib procura compreender porque a crítica pósmoderna ao racionalismo ocidental e ao iluminismo foram e são tidos como aliados do feminismo.

Segundo Jane Flax, são três os pilares do pós-modernismo: a "Morte do Sujeito", a "Morte da Metafísica" e a "Morte da História”. O sujeito “morto" pelo pósmodernismo é descontextualizado e, por isso, capaz de produzir um conhecimento universal. Sua desconstrução está afinada com o feminismo porque o universal e o racional que caracterizam esse sujeito estam associados ao masculino. Assim, em termos feministas, a desconstrução do sujeito abstrato corresponde à "desmistificação do sujeito masculino racional" 52 .

A morte da História, por sua vez, implica renunciar à idéia de que há um encadeamento entre os momentos históricos que dá sentido a uma metahistória, a uma narrativa consistente acerca do rumo da história da humanidade em direção ao

\footnotetext{
J. Idem.

${ }^{49}$ Butler, J.

${ }^{50}$ Benhabib. "Feminism and the question of postmodernism in Benhabib", S. Situating the Self: Gender, community and postmodernism in contemporary ethics. New York: Routledge, p. 204

${ }^{51}$ Referência- Jane Flax- ver texto Benhabib

${ }^{52}$ Idem, p. 205.
} 
progresso $^{53}$. Essa idéia também se revelou útil ao feminismo porque essa história abrangente e homogênea exclui a narrativa de grupos sociais, como o das mulheres, que têm um longa história de marginalização social. ${ }^{54}$.

E, finalmente, a morte da metafísica é incorporada ao feminismo pós-moderno na forma de um "ceticismo feminista em relação à razão transcendental". Essa é uma questão de interesse do feminismo porque a contextualização do sujeito e das condições em que o conhecimento é produzido remete aos interesses que determinam essas condições ou, como diria Focault, remetem às relações de poder que estão por trás da "regra disciplinar". Para a teoria feminista, diz Jane Flax, os interesses em questão são aqueles que determinam a dinâmica das relações de gênero no campo social, econômico, político e na "constituição simbólica das diferenças de gênero"

Benhabib distingue duas versões de "morte do sujeito" moderno. A primeira, a versão fraca, situa o sujeito no contexto de várias práticas sociais, lingüísticas e discursivas; e a segunda, a versão forte, considera o sujeito apenas uma entre muitas posições na linguagem ${ }^{56}$. A versão forte, portanto, diz Benhabib, implica diluir o sujeito em uma rede de significados que não é construída por ele, pois à medida que se considera o sujeito como apenas mais uma posição na linguagem, os conceitos de intencionalidade, responsabilidade, auto-reflexibilidade e autonomia sãom postos de lado $^{57}$. Mas esses conceitos, diz a autora, são indispensáveis para o feminismo e para todos os movimentos sociais, pois sem eles os sujeitos perdem sua condição de agente, de autor da história ${ }^{58}$.

Ainda que reconheça que uma subjetividade que não seja estruturada pela linguagem seja inconcebível, ela sustenta que isso não deve ser confundido com a idéia

\footnotetext{
${ }^{53}$ Ver Benhabib, S. ..p, 208 e ss.

${ }^{54}$ Ver Benhabib, S. "Feminism and Postmodernism: an uneasy alliance”..., p. É preciso observar que Butler propõe a desconstrução do sujeito não apenas porque o discurso oficial teria excluído as mulheres, mas porque o próprio discurso feminista teria excluídos mulheres em condições sociais menos favorecidas.

${ }^{55}$ Benhabib. Idem, p.213.

${ }^{56}$ Benhabib, S. Feminism and Postmodernism.., p. 139. Sobre a morte do sujeito em uma versão forte ver $\mathrm{o}$ argumento de Jane Flax em Flax, J. Thinking fragments, psychoanalysus, feminism and postmodernis in the contemporary West. Berkley: university of California, 1990.

${ }^{57}$ Benhabib, S. Idem, p. 140.

${ }^{58}$ Para Benhabib, os seres humanos são ao mesmo tempo autor e personagens da história, ou seja, têm sem suas mãos a possibilidade de definir o rumo de sua história, mas o fazem dentro de um contexto intersubjetivo cujo texto é anterior à sua atuação. Ver Benhabib, idem, p. 140.
} 
de que somos mera extensão de nossa história. Contextualizar o sujeito não é o mesmo que considerá-lo mero produto de seu contexto ${ }^{59}$.

Benhabib sugere que Butler assume essa versão forte da morte do sujeito. Ela afirma que sua idéia de que não há nada anterior à performance de gênero, que não há um agente atrás da ação, é incompatível com a possibilidade de mudar o rumo da ação. Afinal, pergunta Benhabib retoricamente:

"se formos apenas a soma de performances de gênero, há alguma chance de parar a representação por algum tempo; Não é exatamente esse o ponto nevrálgico da luta pela igualdade de gênero: Certamente podemos criticar a supremacia da identidade política e desafiar a supremacia das posições heterosexistas e dualistas no movimento de mulheres. No entanto, esse desafio é pensável dispensando-se completamente todo conceito de subjetividad,e ação e autonomia (grifos meus) $^{60}$.

$\mathrm{O}$ argumento de Benhabib, enfim, é o de que a morte do sujeito moderno conduz também à morte da ação e da autonomia. Afinal, diz a autora, se o sujeito é produto das relações de poder de seu meio, como ele resistirá a essas relações que o constituírami Como é possível o "eu ser constituído pelo poder e não ser determinado por ele ¿"61.

Para Benhabib isso não é possível. Na tentativa de situar o sujeito em uma dada condição social, o feminismo pós-moderno perdeu uma ferramenta indispensável para que o feminismo funcione como crítica: a autonomia do sujeito.

O erro pós-moderno considerou o sacrifício da autonomia uma condição necessária para a contextualização do sujeito. Benhabib afirma que esse sacrifício é não apenas desnecessário, mas também nocivo aos propósitos do feminismo. Ao invés de se resignar à impotência a que o pós-modernismo leva a crítica social, o feminismo deve investigar modos de contextualização do sujeito que preservem sua capacidade de promover transformações sociais visando relações de gênero mais igualitárias ${ }^{62}$.

Em relação à morte da metafísica, Benhabib também está de acordo com a crítica da razão cientificista que dominou a modernidade; ela também sustenta que o

\footnotetext{
${ }^{59}$ Inserir nota Benhabib

${ }^{60}$ Benhabib, Idem, p. 141.

${ }^{61}$ Benhabib, Feminism and Postmodernism.., p. 218.

${ }^{62}$ Benhabib, p. 211 e 215.
} 
feminismo deve ser cético em relação à razão de um sujeito dotado de capacidades cognitivas anteriores à sua imersão histórica e cultural. No entanto, ela afirma que a razão transcendental pode ser rejeitada sem que seja preciso abandonar a idéia de que a razão é o motor da capacidade crítica do ser humano e de sua capacidade de formular e justificar concepções de igualdade que, embora abrangentes, não estão desvinculadas de um contexto ${ }^{63}$.

Finalmente, em relação à "morte da História”, Benhabib afirma estar de acordo com a rejeição das grandes narrativas históricas pelo feminismo, uma vez que elas não sãom capazes de abarcar a fragmentação da sociedade e os conflitos entre seus segmentos, que desaparecem sempre que a sociedade é reduzida a uma unidade estável e homogênea.

Embora Benhabib reconheça que Lyotard, Foucault e Derrida decretaram o fim da metanarrativa histórica em razão de sua preocupação com a pluralidade, ela afirma que foram longe demais. Ela sustenta que a oposição extremada à História afasta o interesse epistemológico na historiografia das lutas pela inclusão de atores (como as mulheres) marginalizados da narrativa oficial ${ }^{64}$. Sem a reconstrução histórica dessas lutas, a história dos excluídos fica sem visibilidade e, assim, não é possível "repensar as relações entre política e memória histórica" ${ }^{\text {"65 }}$.

Benhabib conclui seu argumento contra a compatibilidade entre pósmodernismo e feminismo apontando os principais defeitos da "crítica situada" pós moderna, ou seja, a única crítica possível depois da morte do sujeito, da história e da metafísica.

O primeiro defeito está na adoção de uma crítica que evita a racionalidade transcendental sacrificando todo modo de normatização. O problema dessa crítica, diz Benhabib, está no fato de isso reduzir a filosofia à mera descrição das condições de

\footnotetext{
${ }^{63} \mathrm{O}$ universal que Benhabib, inspirado em Habermas, refere-se às condições sob as quais cada comunidade irá julgar a validade das proposições acerca da verdade. Residira, portanto, no fato de que essas condições, as chamadas condições de validade, emergem em todos os contextos. No entanto, conteúdo dessas condições não é universal, mas sim relativo ao contexto específico no qual foi construído. Benhabib. Feminism and the question of postmodernism..., p. 219.

${ }^{65}$ Benhabib, p. 222.
} 
validade da ação e do conhecimento em determinados contextos, comprometendo sua função de formular justificações para essas condições de validade ${ }^{66}$.

As investigações sobre validade supõem critérios normativos que para os pósmodernos nada mais são do que regras disciplinares que exprimem interesses daqueles que ocupam uma posição privilegiada nas relações de poder. Mas sem alguma normatividade, pergunta Benhabib, como é possível para o feminismo qualificar a discriminação de gênero como uma injustiçą

O segundo defeito da crítica situada está relacionado à impossibilidade de o sujeito olhar seu contexto com certo distanciamento. Benhabib opõe-se a essa idéia observando que mesmo nos momentos históricos em que a cultura, a sociedade e a tradição são rigorosamente uniformizadas e cristalizadas, como nos regimes totalitários, sempre resta algum espaço para o distanciamento crítico dos sujeitos. Entre outros exemplos, Benhabib menciona os filósofos da Escola de Frankfurt que, mesmo imersos em um regime totalitário, puderam se exilar, não apenas geograficamente, mas também mentalmente, dos consensos de seu meio ${ }^{67}$.

No entanto, Benhabib salienta que distanciamento crítico não requer um sujeito abstrato. Em suas palavras:

“(...) deixar o lar não é o mesmo que terminar em nenhum lugar; é ocupar um espaço fora dos muros da cidade, em um país de refúgio, em uma realidade social diferente. (...) Talvez a nostalgia pela crítica situada seja uma nostagia pelo lar, pelas certezas de nossas próprias culturas e sociedades em um mundo em que nenhuma tradição, nenhuma cultura e nenhuma sociedade pode existir sem a interação e a colaboração, confronto e intercâmbio" 68 .

Assim, paradoxalmente, na tentativa de superar a concepção metafísica e reificada do sujeito moderno, o pós-modernismo reificou a cultura, revelando uma

\footnotetext{
${ }^{66}$.Benhabib. Idem, PP.224.

${ }^{67}$ Benhabib, p. 227

${ }^{68}$ Benhabib, Idem.
} 
surpreendente relutância em aceitar os traços mais característicos da pós-modernidade: os intercâmbios culturais, a dificuldade em delimitar fronteiras e o descentramento do sujeito, ou seja, a dificuldade de o sujeito se identificar com um contexto específico.

A conclusão de Benhabib, enfim, é a de que o pós-modernismo compromete a força contestadora do feminismo porque o sujeito que se confunde com seu meio é incapaz de questionar seus valores e de conceber arranjos sociais e políticos diferentes dos que estão vigentes em seu contexto. Mas o mais curisoso, diz a autora, é que o próprio pós-modernismo revela uma tendência a um certo anacronismo e, portanto, à descontextualização. Afinal, a concepção de sujeito irremediavelmente vinculado a um determinado contexto soa obsoleta em uma época em que a delimitação dos espaços culturais sociais e políticos torna-se cada vez mais imprecisa ${ }^{69}$.

\section{c) Nancy Fraser: entre a crítica moderna e pós moderna}

Nancy Fraser, em seu artigo "False antithesis: a response to Seyla Benhabib and Judith Butler", afirma que não é necessário e nem desejável escolher entre normatividade e desconstrução do sujeito. A intenção de Fraser é preservar os melhores elementos de cada paradigma de forma a preparar o terreno para sua integração na teoria feminista.

Fraser considera que há entre Benhabib e Butler uma diferença de ênfase. Enquanto a primeira coloca o foco na ação do sujeito, na sua capacidade crítica, negligenciando a questão do poder, a análise de Butler destaca o poder e descuida de recursos indispensáveis para a crítica social, como a construção de uma concepção de igualdade e a capacidade de o sujeito questionar o poder.

Sua tese é a de que as debilidades de Benhabib podem ser superadas com a incorporação da concepção de poder de Butler, e as deficiências de Butler podem ser sanadas pela universalidade e normatividade presentes em Benhabib.

\footnotetext{
${ }^{69}$ Benhabib. Idem, p. 227.
} 
Em relação às críticas de Benhabib a Butler, Fraser sustenta que a primeira debate com uma versão excessivamente forte de pós modernismo, que é defendida por Jane Flax, citada por Benhabib, mas não por Butler ${ }^{70}$.

Embora Benhabib afirme que está em busca de um ponto intermediário entre as metanarrativas modernas e a fragmentação da história pós-moderna, ela não explora a possibilidade desse campo intermediário suficientemente. Ao criticar a "morte da história" no pós-modernismo, por exemplo, Benhabib assumiu uma postura ambivalente em relação à posição intermediária de Fraser e Nicholson no artigo " Social Criticism without Philosophy"71.

Nesse artigo, diz Fraser, distinguem-se metanarrativas de historiografias empíricas de larga escala, falibilísticas, revisáveis e não fundacionais. Apesar da larga escala, essa historiografia, ao invés de sintetizar as narrativas de menor escala, estabelece com elas uma relação de tensão recíproca, ou seja, funciona como contraponto à tendência de as narrativas locais se resumirem à mera descrição da diferença, enquanto estas últimas limitam a tendência de a narrativa de larga escala se degenerar em metanarrativa ${ }^{72}$.

Essa posição parece bastante afinada com o que a própria Benhabib afirma defender. No entanto, quando analisa essa proposta, ela sustenta que a narrativa local é incompatível com o interesse emancipatório, o que parece sugerir que apenas as metanarrativas podem cumprir esse papel. Essa posição, no entanto, é incompatível com sua objeção explícita à Filosofia da História ${ }^{73}$.

Fraser acrescenta ainda que a incompatibilidade que Benhabib acredita haver entre antifundacionismo das narrativas locais e emancipação não se sustenta diante de várias formas de historiografia feminista engajadas e localizadas. Como exemplo, Fraser menciona:

\footnotetext{
${ }^{70}$ Fraser; False anthitesis, PP. 208-209.

${ }^{71}$ Idem

${ }^{72}$ Idem, p. 209.

${ }^{73}$ Idem, p. 210.
} 
“(...) as histórias locais que recuperam tradições perdidas de ação ou resistência das mulheres, narrativas que recuperam a historicidade das práticas tidas como femininas por determinação da natureza, histórias que reavaliam formas previamente derrogadas de cultura feminina, e genealogias que desnaturalizam categorias que exprimem códigos de gênero como 'produção'e 'reprodução' ou que reconstroem o subtexto escondido sobre gênero em conceitos como 'classe' e 'estado'. Segundo Benhabib, todos esses tipos de historiografia feminista podem ser caracterizados como pós-modernos, uma vez que se recusam a se legitimarem em uma filosofia da história. No entanto, todas esses estudos são claramente motivados pelo interesse na liberação das mulheres, e têm efeitos emancipatórios" ${ }^{74}$.

Em relação à morte da metafísica, Fraser contesta a idéia de Benhabib de que a crítica situada não leva necessariamente a uma concepção unívoca de cultura. Segundo Fraser, a crítica pós-moderna não entende a cultura como algo homogêneo e imutável; ao contrário, a preocupação em reduzir o alcance da crítica, tornando-a localizada, é conseqüência justamente de o pós-modernismo reconhecer a complexidade das culturas. Fraser também discorda do posicionamento de Benhabib acerca do "distanciamento do crítico". Fraser está de acordo com a idéia pós-moderna de que as práticas que promovem mudanças culturais são elas também culturalmente contextualizadas ${ }^{75}$.

Aproveitando o exemplo de Benhabib do crítico no exílio, Fraser sustenta que mesmo quando geograficamente afastado de seu meio, o sujeito leva sua "comunidade imaginada" consigo, onde quer que esteja. O distanciamento do sujeito, que Benhabib julga ser condição da crítica, não se realiza jamais.

Em relação a Butler, Fraser distingue analiticamente dois aspectos de seus argumento, um ontológica e outro normativo. Butler defende uma ontologia pósestruturalista do sujeito, segundo a qual não é suficiente reconhecê-lo como construído por seu contexto, ele tem que ser reconhecido como um produto de seu meio ${ }^{76}$. Ao contrário do que pensa Benhabib, diz Fraser, essa idéia não exclui a capacidade crítica

\footnotetext{
${ }^{74}$ Idem, p. 210

${ }^{75}$ Idem, p. 212.

${ }^{76}$ Fraser, false anthiteses.. p. 214
} 
do sujeito, mas apenas a concepção de autonomia que pertence a uma estrutura da subjetividade anterior às relações de poder ${ }^{77}$.

No entanto, para Fraser, a capacidade crítica em Butler apresenta algumas das limitações apontadas por Benhabib. Embora Butler refira-se à transformação social com uma conotação positiva, seu argumento não é capaz de formular critérios para distinguir a mudança boa da má, a progressista da conservadora, a opressora da emancipatória ${ }^{78}$.

Enfim, a ontologia de Butler gera restrições no campo da normatividade. Afinal, a adoção da idéia foucaultiana de que o processo de constituição do sujeito implica necessariamente a sua sujeição, não permite vislumbrar um horizonte de igualdade; nem no plano da utopia. A normatividade que aparece implícita em seu texto é a de que "a reificação da identidade é ruim porque gera exclusão" e "a desconstrução da identidade é boa porque é inclusiva". Mas essa normatividade ainda é, diz Frazer, insuficiente para uma teoria crítica feminista",79.

A conclusão de Fraser, enfim, é a de que tanto Benhabib quanto Butler falharam em integrar argumentos críticos-teóricos ao pós-estruturalismo; no entanto, ambas falharam não porque suas perspectivas são irreconciliáveis, mas porque dialogaram com versões demasiadamente fortes das concepções opositoras, concepções estas que não representam nem a posição de Benhabib e nem a de Butler. Nem Benhabib é uma racionalista metafísica, nem Butler é uma relativista anti-racionalista.

A combinação entre o argumento de Benhabib e Butler resulta numa teoria feminista em que as concepções de justificação e normatividade não essencialista e não fundacionalista em Benhabib funcionam como uma alternativa a universalismos de fundamentação metafísica e colocam a devida ênfase na autonomia e na intersubjetividade. No entanto, Fraser acredita que falta a Benhabib reconhecer o papel que as relações de poder cumprem na constituição da subjetividade, conforme faz Butler $^{80}$. Assim, conclui Fraser, a concepção de subordinação de Butler e a concepção de autonomia de Benhabib não são antitéticas, mas sim complementares. Butler

\footnotetext{
${ }^{77}$ Idem

${ }^{78}$ Fraser, p. 215

${ }^{79}$ Fraser, p. 216

${ }^{80}$ Ver Fraser: False anthitesis..., p 212. e Fraser, Foucault on power (completar)- página. E Allen, Amy, The politics of ourselves... Cit, p. 8 .
} 
contribui com o papel descritivo da teoria crítica feminista, enquanto Benhabib contribui para a sua função propositiva.

Essa combinação, porém, não é simples de ser efetuada com sucesso, e tanto Butler quanto Benhabib se opuseram a essa tentativa de Fraser. Segundo Butler, sua opção pelo foco no poder em detrimento da autonomia não decorre apenas de uma questão de ênfase, mas sim do fato de recusar a razão como fundamento da crítica, pois da idéia foucaultiana de que a razão é um instrumento de justificação do poder decorre que a resistência à determinada configuração de poder não deve se fiar na racionalidade. Por isso, o caminho da crítica em Butler está na investigação do processo de construção das "verdades" morais e científicas vigentes, explicitando o papel que o apelo à racionalidade cumpre na sua naturalização ${ }^{81}$.

Benhabib, por sua vez, sustenta que a razão é condição da crítica. A capacidade de julgar, de distinguir o justo do injusto, exige uma normatividade passível de justificação racional. Somente desse modo é possível construir uma concepção de igualdade de gênero em uma teoria da justiça, preocupação tanto de Benhabib quanto de Fraser, mas que Butler, por consequiência de sua objeção à normatividade, não considera ser um projeto possível.

\section{d) Três formas de resistência feminista.}

Judith Buther, Seyla Behabib e Nancy Fraser estão todas buscando alternativas ao sujeito metafísico e à metanarrativa para que o feminismo atenda às demandas de inclusão trazidas pela terceira onda.

No entanto, cada uma delas concebe modos distintos de superar a abstração moderna. Benhabib busca recursos para isso na própria modernidade. Ela quer contextualizar o sujeito sem prejuízo da normatividade e de sua autonomia. Ela o faz buscando a superação da episteme moderna do século XIX na Teoria Crítica do século XX, em particular no pensamento de Jurgen Habermas. Butler, por sua vez, orienta sua

\footnotetext{
${ }^{81}$ Idem, p. 22 e Butler, "J. What is Critique $;$ An essay on Foucault's virtue" in Ingram, David (ed) The Political: Readings in Continental Philosophy. London:: Basil :Blackwell, 2002.
} 
reflexão a partir de outra linha de pensamento. Ela ataca os males da modernidade com base nas reflexões e categorias pós-modernas.

Fraser, por sua vez, tem uma trajetória semelhante a de Benhabib, mas admite fazer concessões ao argumento pós-moderno de Butler, na medida em acredita que sua ênfase no papel do poder na constituição do sujeito supre as deficiências da teoria crítica feminista de Benhabib.

No entanto, a oposição tanto de Butler como de Benhabib a essa tentativa de Fraser sugere que esta última possa ter minimizado a profundidade das diferenças teóricas entre o feminismo moderno e pós-moderno.

A primeira diferença refere-se ao sentido que atribuem à contextualização do sujeito. Tanto Benhabib quanto Butler sustentam que o sujeito é socialmente construído, mas Benhabib preocupa-se em preservar uma capacidade de distanciamento do contexto social, enquanto para Butler esse distanciamento não é possível. Assim, o primeiro tópico da divergência Benhabib-Butler é o sentido de "construção social do sujeito", e não um embate entre "sujeito abstrato" e "sujeito contextualizado", conforme Butler pensa Butler.

A segunda discordância entre ambas diz respeito à concepção de autonomia do sujeito. Benhabib relaciona a autonomia à racionalidade, mas não o faz apelando para uma razão monológica. Sua concepção de racionalidade é dialógica, ou seja, manifestase na interação dos sujeitos por meio da linguagem, e não na reflexão solitária ${ }^{82}$. Assim, em Benhabib, o binômio razão-liberdade persiste, já que é a racionalidade que impulsiona a crítica. Mas sua concepção de racionalidade procura evitar tanto a atomização do sujeito quanto a sua abstração, uma vez que a racionalidade dialógica supõe a interação intersubjetiva e se dá em um ambiente concreto e determinado.

Butler, por sua vez, substitui o par "razão-liberdade" pelo "razão-poder", conforme dito anteriormente. A possibilidade da crítica está justamente na desmistificação da razão como condição da emancipação. Assim sendo, a segunda divergência entre ambas pode ser resumida no papel da razão em suas respectivas concepções de crítica.

\footnotetext{
${ }^{82}$ Benha
} 
Benhabib e Butler divergem também acerca da motivação do sujeito para se engajar na crítica social. O sujeito critica para quê $i$ Benhabib responde sem muitas dificuldades a essa questão porque admite a possibilidade de uma construção intersubjetiva da igualdade. Sua resposta, portanto, é: o sujeito, ou melhor, os sujeitos são críticos porque buscam o reconhecimento mútuo, recíproco, uma distribuição justa de recursos; buscam, enfim, um horizonte igualitário.

Butler, no entanto, encontra mais dificuldades para justificar a motivação da crítica. Primeiramente porque se a assimetria de poder é insuperável, o espaço social em que a identidade se constitui não admite a mutualidade e a intersubjetividade. Butler não oferece recursos para a construção de uma identidade mais inclusiva. O reconhecimento de um grupo é sempre feito pelo sacrifício de outro. A intenção da crítica social, portanto, restringe-se a reorganizar das relações de poder. A luta pela inclusão de uns, implicará a exclusão de outros. Em Butler, portanto, o reconhecimento social sempre envolve a produção de novas assimetrias. ${ }^{83}$. Essa é uma das principais consequiência do fato de Butler sacrificar a normatividade em nome da ênfase no poder, o que parece ser problemático para o feminismo pelas razões apontadas tanto por Benhabib quanto por Fraser.

Finalmente, cada uma dessas concepções supõe diferentes alcances da crítica. Enquanto Benhabib e Fraser defendem críticas estruturais para a desigualdade de gênero, o que as compromete com algum grau de generalização do fundamento dessa desigualdade; Butler admite apenas a crítica fragmentada porque considera que toda generalização traz consigo o germe da homogeneidade e com ele, o da exclusão. Aqui, portanto, a divergência gira em torno da (im)possibilidade de generalização não metafísica. Benhabib e Fraser acreditam que isso é não apenas possível, como necessário; embora busquem modos distintos de justificar essa generalização; enquanto Butler defende a crítica localizada como única alternativa possível ao universalismo metafísico e acredita que, mesmo espacial e temporalmente delimitada, a crítica não perde seu potencial transformador.

\footnotetext{
${ }^{83}$ ver. e Allen, Allen..p.11.
} 
Como se vê, as diferenças entre Benhabib e Butler indicam que as dificuldades de conciliação entre o paradigma moderno e pós-moderno não podem ser subestimadas. Embora o argumento de Fraser pareça convincente quando aponta as contribuições e deficiências em cada um dos paradigmas, a compatibilidade entre eles não é tão evidente. Somente depois de uma análise detalhada desse projeto de Fraser será possível encontrar mais pistas sobre a viabilidade e desejabilidade de "um ponto médio" entre pós-modernismo e modernismo na teoria feminista. 


\section{CAPÍTULO II: Contextualização do Sujeito e Autonomia}

Rejeitar o sujeito moderno e abstrato implica a morte da autonomia? O sujeito contextualizado é ainda capaz de criticar os valores e as normas de seu próprio meio?

Benhabib e Butler afirmam que contextualização não é o mesmo que determinação. Ambas sustentam que a rejeição do sujeito universal e abstrato não leva à morte de sua capacidade crítica. O desacordo entre elas está no modo de contextualização e as implicações que isso tem em suas respectivas concepções de autonomia.

Para Butler, a preocupação de Benhabib em manter uma concepção forte de autonomia mascara o papel das relações de poder na constituição do self. Por isso, na visão de Butler, Benhabib recai no formalismo e abstração do sujeito moderno, apesar de seus esforços em evitá-lo. Benhabib, por sua vez, afirma que Butler sacrifica a capacidade crítica do sujeito em nome da contextualização, comprometendo o caráter emancipatório do feminismo.

No entanto, embora as diferenças entre Butler e Benhabib permaneçam, elas não podem mais ser consideradas diametralmente opostas, como em seu primeiro debate. Com o passar do tempo, elas se aproximaram, sugerindo que Fraser tinha alguma razão em apontar falsas antíteses entre elas. A principal razão dessa aproximação decorre de esclarecimentos que Butler faz em "Bodies that matter" sobre sua concepção de performatividade.

Segundo Benhabib, em "Gender Trouble", a performatividade parecia ser uma série de atos desconectados entre si. Mas em "Bodies that matter", Butler enfatiza que esses atos não são isolados. Os atos que constituem a performance são encadeados porque é a sua repetição constante que lhe dá uma aparência de algo óbvio, natural. É pela repetição que permanecem ocultos os interesses beneficiados pela norma disciplinar ${ }^{84}$.

\footnotetext{
${ }^{84}$ Benhabib, S. "Sexual Differences and Collective Identities, Benhabib.S. "Sexual Differences and Collective Identities", in Signs, Winter, 1999, p. 338.
} 
Entretanto, a repetição não é apenas um meio de reafirmar a norma. Ela pode ser também um meio de confrontá-la, pois cada nova performance é uma reinterpretação. Cada indivíduo imprime um elemento de originalidade em sua forma de reproduzi-la.

Benhabib reconhece, enfim, que essa forma de conceber a performance concilia repetição e inovação de uma forma interessante. No entanto, ela insiste em que o conceito de performance carece de uma concepção de intencionalidade humana, capaz de explicar porque as repetições podem ser também inovações, ou seja, porque as performances podem ser críticas ${ }^{85}$.

Assim, Benhabib conclui que a concepção de self de Butler é insuficiente para justificar a crítica social. Ela formula então sua própria concepção de self a fim de conciliar os pontos fortes do "self performativo" com uma concepção de autonomia mais robusta do que a de Butler. $\mathrm{O}$ esboço desse conceito aparece em seu livro "Situating the self" (1992) e no "The reluctant modernism of Hannah Arendt" (1996). Mas a concepção de self narrativo somente será completamente desenvolvida em 1999, no artigo "Sexual Difference and Collective Identities" (1999).

Este capítulo tem dois objetivos. O primeiro é analisar os reflexos da concepção de self em Benhabib em sua noção de crítica; e o segundo é apontar os pontos comuns e divergentes entre as noções de crítica de Butler e Benhabib.

\section{I) O Self narrativo}

"Ele se espreguiçou. Levantou-se. Ficou de pé completamente nu diante de nós, e enquanto as trombetas soavam: "A verdade, a verdade" nós não tivemos nenhuma escolha a não ser confessar: ele era uma mulher (...).

Orlando tornou-se uma mulher, não há dúvida disso. Mas em relação a todas as outras coisas, Orlando permaneceu exatamente quem era. A mudança de sexo, embora tenha alterado seu futuro, não alterou em nada sua identidade. Suas faces permaneceram, conforme provam os retratos, praticamente iguais. Suas lembranças puderam recuperar todos os eventos de sua vida passada sem encontrar nenhum

\footnotetext{
${ }^{85}$ Idem, p. 339.
} 
obstáculo (...). A mudança parece ter sido realizada sem sofrimento e completamente, de tal maneira que a própria Orlando não se mostrou surpresa"

Benhabib identifica no romance "Orlando" de Virginia Wolf um exemplo de "self narrativo". A história é contada da perspectiva de um observador (a), um biógrafo (a), ele( a) próprio um personagem, que narra a identidade de Orlando. Orlando é um homem nobre que vive no final do século XVI, que depois de um transe acorda uma mulher no século XIX. Há, portanto, duas rupturas em sua identidade: uma histórica e outra de gênero. Mas essas rupturas, surpreendentemente, não alteram o núcleo de seu self. Ele (a) permanece a mesma pessoa. Ao longo do livro, porém, Woolf aborda a dificuldade de Orlando em adaptar-se ao comportamento feminino. Surpreende-se com o enorme trabalho a que uma mulher precisa se dedicar para ser feminina. Ser mulher não é uma decorrência automática da sua transformação física. Assim, Woolf sugere que a identidade de gênero tem um forte componente comportamental e que a anatomia e os papéis de gênero não são o núcleo da identidade do self ${ }^{86}$. Quando o futuro marido de Orlando declara-se a ela com lágrimas nos olhos, o caráter comportamental e cultural do feminino e do masculino fica evidente: "Que homens choram tão freqüentemente quanto as mulheres, Orlando sabia por sua própria experiência como homem, mas ela estava começando a perceber que as mulheres devem ficar chocadas quando um homem revela emoção em sua presença; então, ela ficou chocada (p.88)”

Woolf sugere que há um núcleo do self quando afirma que Orlando permaneceu a mesma pessoa depois de se tornar uma mulher. No entanto, fica claro também que ser mulher ou homem é uma condição aprendida e reproduzida, propondo uma dessencialização da identidade de gênero.

No entanto, em outra passagem, Woolf desafia também a própria noção de núcleo do self quando se refere a Orlando no plural ("suas faces, suas lembranças"). Essa idéia aparece ainda mais claramente quando escreve: "Uma biografia é considerada completa somente se abarcar seis ou sete selves, mas uma pessoa pode ter mais de mil selves. No entanto, não sei por que, o self consciente insiste muitas vezes em ser apenas um self, que condense todos os demais em um "self-chefe" 87.

\footnotetext{
${ }^{86}$ Benhabib, 343, 1999.

${ }^{87}$ Idem, p. 356.
} 
Woolf levanta ao menos duas questões: 1) como se constitui a identidade de gênero? 2) Há um núcleo duro do self que independe da identidade de gênero? No romance, não há respostas inequívocas a essas questões ${ }^{88}$. Woolf, no entanto, é insistente no caráter comportamental e intersubjetivo da constituição da identidade de Orlando. Suas ações e reações não são instintivas ou biologicamente determinadas. São condicionadas pelas expectativas do interlocutor e vice-versa, expectativas apreendidas pela sua observação do comportamento feminino e do masculino de uma perspectiva ao mesmo tempo interna e externa. O (a) biógrafo(a) também cumpre um papel fundamental aqui. É a sua narração que condensa a identidade da personagem. Durante todo o livro, a narração refere-se à personagem principal como Orlando, embora os pronomes pessoais sejam alterados para o feminino depois de sua transformação em mulher. A forma de contar a história de Orlando alterna a ênfase na estabilidade e na instabilidade de sua identidade. É assim que Woolf garante a ambigüidade provocativa da identidade de gênero em seu romance ${ }^{89}$.

Benhabib explora essas ambigüidades para buscar uma resposta para as questões levantadas por Woolf e construir sua própria concepção de self narrativo. Seu ponto de partida é o conceito "redes de interlocução" de Hannha Arendt.

As redes de interlocução são o meio do qual fazemos parte desde nosso nascimento. É ali que nosso self será desenvolvido. Depois de nosso nascimento físico, nascemos também para o mundo humano, através do diálogo com os demais membros da rede da qual fazemos parte ${ }^{90}$. Chegar ao mundo equivale a entrar numa teia de relações humanas que já existem. Mas o ato que dá início à nossa condição de agente é responder à pergunta “quem é você?”. Quando articulamos essa resposta, damos início ao processo de comunicação do qual somente saímos quando morremos ${ }^{91}$.

A comunicação humana é inescapável. Primeiramente, porque estamos desde o nascimento imersos em redes de relacionamento. Jamais experimentamos o isolamento. Em segundo lugar, porque essa interação é sempre mediada pela linguagem. Essa mediação é necessária porque somos todos diferentes uns dos outros. Não podemos nos reconhecer totalmente em ninguém. Por isso é preciso que o outro nos informe sobre si

\footnotetext{
${ }^{88}$ Idem, p. 358

${ }^{89}$ Idem, p. 358.

${ }^{90}$ Idem.
} 
mesmo para que ele se torne inteligível para nós. No entanto, o diálogo somente é possível porque, apesar de diferentes, somos também todos iguais. Se não fôssemos iguais, não poderíamos interagir pelo discurso, pois cada ser humano seria totalmente ininteligível para o outro. ${ }^{92}$

Enfim, não é no isolamento e no silêncio que nossa identidade se constitui. É na convivência e comunicação com outros seres humanos, que vamos descrevendo e criando a nós mesmos ${ }^{93}$. O espaço das aparências é o espaço da revelação da identidade porque o traço distintivo da ação humana é a intersubjetividade. Cito Benhabib:

“(...) os seres humanos só podem agir e falar com outros. E o fazem à medida que aparecem para os outros. Nós podemos viver em solidão, podemos pensar em solidão, mas não podemos ser generosos ou miseráveis, corajosos ou covardes, gentis ou cruéis sem a presença dos outros (...). A tese filosófica aqui é que as ações apenas podem ser identificadas através de uma narrativa que é exposta aos outros e a nós mesmos. Os elementos mais elementares do "o que” da ação é a identificação do agente, de suas intenções, da qualidade do ato, do contexto em que o agente está engajado. Essas características da ação, no entanto, somente podem ser identificadas narrativamente, pelas histórias que contamos, pelas construções narrativas do 'quem', do " o que", do "por que”, do "como" e do "para que”. A ação é revelada no discurso. $(\text { tradução livre })^{94}$.

Em suma, ser humano significa interagir, aparecer no mundo com os outros, dialogar. Assim, não há espaço para uma essência metafísica, que se esconde atrás das aparências. Nosso self é pura aparência. Ele emerge porque nós o revelamos para os outros, quando nos comunicamos. Enfim, não há um self anterior ao mundo, anterior à

\footnotetext{
${ }^{91}$ Idem, p. 191.

${ }^{92}$ Arendt, Hannah. , p. 189 e ss.

93 Idem.

94 “ (...) human beings can act and speak only with others, and insofar as they appear to others. One can live in solitude, one can think in solitude, but one cannot be generous or miserly, courageous or cowardly, kind our hurtful without the presence of the others. (...) The philosophical thesis here is that actions can only be identified through a narrative that is disclosed to others and to ourselves. The 'Whatness' of an action requires at the very least the identification of its doer, of his or her intentions, of the quality of the act, of the context within which it is engaged. These features of action, however, can only be identified narratively, by the stories we tell, by the narratives we construct of the who, the what, the why, the how, and the what for. Action is disclosure in speech" Benhabib. The reluctant modernism of Arendt, PP. 112.
} 
intersubjetividade e que esteja totalmente sob nosso controle. Nosso self é uma criação conjunta de todos os participantes da teia de interlocução da qual fazemos parte.

Benhabib acrescenta ao argumento de Arendt de que todos nascem em redes de interlocução, a idéia de que nossa primeira rede narrativa é familiar e de gênero. É essa narrativa que funciona como ponto de partida para a construção das demais macronarrativas $^{95}$.

Essa primeira narrativa, no entanto, não se confunde com uma essência da personalidade dos seres humanos. A identidade de gênero não forma um núcleo da identidade imutável, uma vez que o que está em jogo na narração não é o assunto da história que é contada, mas sim a capacidade de contar histórias sobre o que somos ${ }^{96}$.

O conteúdo dessa história está sempre em mutação. Jamais concluímos uma narrativa cristalizada sobre nossa vida ${ }^{97}$. Nem mesmo nossas lembranças passadas são estáveis, pois elas somente podem ser revividas através de narrativas do presente. Serão, portanto, as relações intersubjetivas do presente, que darão sentido às histórias do passado, ao longo de toda nossa vida. Cito:

“[nossas memórias] somente podem ser revividas no presente, como algo que tem sentido em nossa narrativa presente. Elas existem apenas 'para nós', nosso acesso a elas nunca pode ser “nelas mesmas' ou em um 'ich'. A tentativa de reviver essas memórias fora do horizonte temporal do presente coloca o self em perigo de regressão, dissipação e perda das fronteiras do ego"98.

Entendendo a identidade pessoal como um resultado desse processo contínuo de narração, ela não conduzirá à coerência e estabilidade que Butler lhe atribui, pois a capacidade de narrar a história pessoal leva a um produto temporário ${ }^{99}$. Enfim, em

\footnotetext{
${ }^{95}$ Benhabib, S. Sexual Difference and Collective Identities.., p. 343.

${ }^{96}$ Idem, p. 344

${ }^{97}$ Idem, p. 346.

98 Citação original. "They can only be relieved in the present, as meaningful within our present narrative. They are only 'for us', our access to them can never be 'in itself', or an "ich". The attempt to relive these memories outside the temporal horizon of the present would put the self in danger of regression, dissipation, and loss of ego bounderies". Idem, p.
}

\footnotetext{
${ }^{99}$ Idem, p.
} 
Benhabib, a identidade não é uma categoria coesa e definitiva, pois o núcleo do self não está numa essência natural.

Além do essencialismo natural, Benhabib rejeita também a idéia de que a cultura forja elementos imutáveis da personalidade do indivíduo. A integridade do self não depende da adesão permanente a uma moral convencional inevitavelmente atrelada à personalidade. Essa idéia fica clara quando Benhabib discute a concepção de self em Charles Taylor. ${ }^{100}$.

Em “As fontes do Self”, Charles Taylor também formula uma concepção de self narrativo. Mas para ele, o núcleo da identidade é formado por um conjunto de "fortes comprometimentos avaliativos" ("strong evaluatives commitments"), que as pessoas herdam de seu contexto. A personalidade de cada ser humano é inseparável desses comprometimentos. Eles formam o "horizonte", o pano de fundo, que funciona como referência para que o sujeito faça escolhas, julgue o que é bom, valioso e defina as posições que deseja $\operatorname{apoiar}^{101}$.

Esse pano de fundo, porém, não é o único elemento que forma o self. Em Taylor, há também uma dimensão do self que é formada nas redes de interlocução, assim como em Arendt e em Benhabib. No entanto, Benhabib procura mostrar que o self é inteiramente formado nas redes de interlocução. Não há uma dimensão formada pelo horizonte de fortes comprometimentos avaliativos permanentes e indissociáveis do self $^{102}$. Para ela, Taylor confunde as condições de possibilidade da ação humana com uma concepção forte de moralidade. Benhabib sustenta que é possível pensar na primeira sem a segunda. É desse modo que a identidade pode ser concebida sem um núcleo essencialista ${ }^{103}$.

Para Benhabib, são as atitudes que tomamos em relação aos fortes comprometimentos avaliativos e a forma como descrevemos essas atitudes que vão construindo nossa identidade ao longo do tempo. Em alguns casos, essa atitude pode até ser a de manter certo distanciamento em relação aos valores de nosso meio. O sedutor e o irônico são exemplos deste último caso. A identidade de ambos não está vinculada a

\footnotetext{
${ }^{100}$ Idem, p. 346.

${ }^{101}$ Idem, PP. 343 e 344 . Ver também Taylor, Charles. The source of the self: the making of modern identity. Cambridge Mass: Harvard University Press, 1989, pp. 27 e ss.

${ }^{102}$ Idem, p. 345.
} 
um forte comprometimento avaliativo. Eles são apenas observadores, que não se comprometem com julgamentos sobre o certo e o errado. Mas isso não significa que não tenham identidade. Tanto o sedutor quanto o irônico distanciam-se de seu horizonte, mas nem por isso seus selves se desintegram totalmente ${ }^{104}$.

Em suma, a integridade moral não é indissociável da identidade. Assim, não há um núcleo essencial e permanente da identidade. O seu núcleo é formado por um material que está sempre em mutação. São as nossas atitudes em relação às questões morais que nos constituem, e não valores entranhados em nosso self ${ }^{105}$.

O núcleo do self em Benhabib está na "capacidade de atribuir significado à nossa história de vida". Isso não se confunde com uma pretensão de obter uma coerência permanente. A narrativa que fazemos não requer um começo, um desenvolvimento e uma conclusão linear e coerente. Como jamais chegamos a uma versão definitiva da nossa história, como sempre a contamos e recontamos, a história será sempre reinterpretada. Isso significa que toda história envolverá mais de uma narrativa.

Benhabib, assim, responde à crítica de Butler à identidade formulando uma concepção de identidade contextualizada e provisória. A coerência do self narrativo em Benhabib é passageira porque a história não é jamais encerrada em caráter definitivo. Ela será sempre sujeita a reinterpretações ou, como diz a própria Butler, a ressignificações ${ }^{106}$. No entanto, apesar de a identidade em Benhabib ser contextualizada, ela não é descentrada a ponto de perder totalmente seu núcleo. Esse núcleo, porém, corresponde a uma "habilidade de narrar" e não a um conteúdo determinado que pudesse lembrar uma essência imutável.

Em suma, no processo de formação do self narrativo de Benhabib não há um “agente atrás da ação", ou seja, não há um self abstrato que se constitui antes de agir. O agente se constitui à medida que age e, em Benhabib, isso equivale a dizer " à medida que dialoga" com os outros nas redes de interlocução. O "self narrativo" tampouco 
implica uma identidade imutável, cristalizada no tempo, uma vez que ele se constitui num processo comunicativo que perdura durante toda sua existência ${ }^{107}$.

Finalmente, o fato de sermos os narradores de nossa história não nos dá total domínio sobre quem somos ou seremos, pois nós não somos os únicos autores de nossas narrativas. Afinal, sempre que a narramos, nós nos dirigimos aos demais. Mas os ouvintes não são passivos. Eles interpretam o que dizemos e tentam conciliar nossa história de vida com a narração de sua própria história. Isso significa que ninguém é livre para inventar a si mesmo. Afinal, nossas narrativas afetam e condicionam as das demais pessoas e vice-versa ${ }^{108}$.

Mas se não somos donos de nossa história, como podemos mudar seu script? A principal acusação de Benhabib a Butler é a de matar a autonomia do sujeito, de tornálo incapaz de iniciativa, incapaz de avaliar criticamente seu contexto. Mas se também em Benhabib o sujeito não é o dono soberano de sua história, como ele poderá modificá-la? Qual é o alcance e o limite da autonomia do sujeito em Benhabib? O que, afinal, ela entende por crítica e em que ela se diferencia da crítica em Butler?

\section{II) A capacidade crítica do self narrativo}

"O ego não é mestre em sua própria casa”. Essa é uma das mais importantes contribuições da psicanálise para o feminismo com a qual tanto Benhabib como Butler estão de acordo. A divisão freudiana do self em consciente e inconsciente sugere que toda história que contamos sobre nós mesmos é acompanhada de um subtexto do qual não temos conhecimento ${ }^{109}$.

As feministas pós-modernas interpretam essa idéia como um alerta contra o caráter opressor da identidade. Entendem que o "eu" capaz de controle total sobre seus atos é uma ficção, como diz Freud, mas é uma ficção que tem como propósito político esconder as disputas de poder que constituem o sujeito ${ }^{110}$.

\footnotetext{
${ }^{107}$ Idem, p. 347.

${ }^{108}$ Ide, p. 198.

${ }^{109}$ Idem, p. 349.

${ }^{110}$ Idem,
} 
Benhabib, porém, propõe uma interpretação distinta. A identidade, diz ela, não precisa ser vista como uma categoria suspeita. A idéia de que o "eu" não é o mestre de sua própria casa pode significar apenas que "nossa própria casa não é apenas habitada por nós"111.

Se vivemos entranhados em redes de interlocução, estamos sempre em situação de interação com outros. Nessa interação, assumimos um ponto de vista específico que será comunicado e negociado com o dos demais. Os sujeitos, portanto, encontram o limite do controle de suas ações na intervenção que os outros participantes da rede de interlocução fazem em nossas próprias ações ${ }^{112}$.

No entanto, o fato de jamais nos desvencilharmos das redes de interlocução não implica que não possamos avaliá-la criticamente. Nós fazemos avaliações críticas à medida que reinterpretamos nossa história, uma história sempre entremeada pela história dos outros participantes da rede ${ }^{113}$. A ação do sujeito contextualizado e de identidade provisória consiste na capacidade de condensar o conjunto de narrativas que nos envolve em uma história de vida que seja compreensível para nossos interlocutores, bem como seja capaz de nos constituir como sujeitos singulares ${ }^{114}$.

Embora sempre façamos isso limitados pelos códigos de linguagem estabelecidos em uma dada cultura, preservamos nossa capacidade de contar a história de vários modos. Nossa cultura nos fornece a gramática, o alfabeto, que usaremos para construir nossas narrativas, que estão imersos em um dado contexto. Assim, a história que contamos e que é contada sobre nós no processo contínuo de construção da identidade é histórica e culturalmente específica. Nosso aparecimento na rede de interlocução já está imbuído de relações de poder e de gênero. No entanto, sempre podemos atribuir novos significados a essa história, à medida que a recontamos. Sempre podemos mudar o script ${ }^{115}$.

A "questão do véu" na França é um bom exemplo disso. O Estado francês proibiu estudantes muçulmanas de usarem o véu nas escolas públicas. A intenção foi impor mais autonomia e igualdade, proibindo o uso de um símbolo da desigualdade de

\footnotetext{
${ }^{111}$ Benhabib. "Sexual Difference and Collective Identities..", p. 349.

112 Idem.

113 Idem, p. 344

${ }^{114}$ Benhabib, “Sexual Differences and Collective Identities"..., 1999, p. 343.
} 
gênero ditado pela religião islâmica. No entanto, a reação das estudantes foi surpreendente. Elas se organizaram e saíram às ruas para lutarem pelo direito de continuar usando o véu. Segundo Benhabib, essa manifestação não pode ser simplesmente interpretada como uma submissão automática à sua cultura sexista. $\mathrm{O}$ medo de uma eventual punição pelo descumprimento da norma religiosa não é suficiente para explicar porque elas ousaram enfrentar a proibição do estado francês ${ }^{116}$.

Embora reconheça que o medo pudesse também estar presente, Benhabib interpreta a ação das meninas de outro modo. Para ela, essa manifestação representou uma crítica à condição dos cidadãos muçulmanos na França. Embora o véu tenha sido historicamente um símbolo de opressão das mulheres, as meninas muçulmanas naquele contexto lhe atribuíram um novo significado. De símbolo da opressão feminina, tornouse um símbolo de afirmação da identidade cultural $^{117}$.

Enfim, apesar de sermos todos formados por nosso meio, podemos criticá-lo. Benhabib diz ainda que a própria noção de "nosso meio" está cada vez mais fluida. O caso do véu mostra que a tradição não pode ser considerada um bloco homogêneo e estável. As meninas muçulmanas combinaram elementos da cultura francesa e da islâmica para buscarem sua autonomia. Elas se rebelaram contra o nacionalismo francês exibindo símbolos de sua cultura. Mas o fizeram respaldadas por códigos e valores políticos franceses ${ }^{118}$.

Benhabib reconhece o papel que a tradição cumpre na formação do self. No entanto, ela sustenta que não há nada que esteja inevitavelmente atrelado à nossa identidade. Nós sempre podemos nos distanciar de nossa tradição. O diálogo exige o distanciamento de nossas posições específicas. Para interagir com os outros, precisamos nos colocar no lugar do "outro". Para Benhabib, porém, não basta assumir a posição de nosso interlocutor real ou, como diz ela, do "outro concreto". É preciso também adotar a perspectiva do "outro generalizado".

\footnotetext{
115 Idem, p. 345

${ }^{116}$ Benhabib. Claims of Culture: equality and diversity in the Global Era, Princeton: Princeton University Press, 2002, p. 117.

${ }^{117}$ Idem.

${ }^{118}$ Idem. Sobre essa discussão ver também Neves, R. Reconhecimento, Multiculturalismo e Direitos: contribuições do debate feminista a uma teoria crítica da sociedade. (dissertação de mestrado ). Universidade de São Paulo. Faculdade de Filosofia, Letras e Ciências Humanas, 2005, p.
} 
O "outro generalizado" representa o ponto de vista universal. Permite a visualização externa das normas compartilhadas que condicionam a interação entre o "eu" e o outro". O outro generalizado nos permite ver cada indivíduo como um ser racional, dotado de direitos e deveres que gostaríamos de atribuir a nós mesmos. Mas essa universalidade é ponderada pela posição do "outro concreto", que nos faz reconhecer as especificidades dos demais integrantes da rede de interlocução. É assim que compreendemos sua singularidade ${ }^{119}$.

A posição do "outro concreto" inclui no diálogo as assimetrias e as diferenças entre os participantes da rede de interlocução, enquanto a posição do "outro generalizado" representa a possibilidade de entendimento apesar dessas diferenças. As diferenças de necessidades e desejos reais não afetam a universalidade da dignidade moral. Desse modo, Benhabib combina o particular com o universal a fim de abarcar o reconhecimento das diferenças e da igualdade entre os participantes da rede de interlocução $^{120}$.

Voltando às questões levantadas por Woolf: 1) como se forma a identidade de gênero? 2) Há um núcleo duro do self que independe do gênero? A resposta de Benhabib à primeira questão é mais direta. Como qualquer identidade, o gênero é formado por narrativas que emergem das redes de interlocução. Essas narrativas estão sempre alterando o significado do masculino e do feminino e criando outras categorias que combinam elementos de ambos ${ }^{121}$.

A resposta à segunda questão levanta mais dúvidas. Amy Allen sustenta que Benhabib não leva sua concepção de self narrativo até às últimas consequiências. Apesar de conseguir desvincular o gênero da essência do sujeito, ela mantém a idéia de um núcleo duro do self que precede e transcende o gênero. Cito Allen:

"Faz sentido (...) pensar no gênero como uma narrativa que podemos escolher como formular em nossa própria história de vida? Ou o gênero é em algum sentido uma precondição para narrar? Se for assim, e se, como a própria Benhabib sustenta, a

\footnotetext{
${ }^{119}$ Benhabib, S. Critique, Norm and Utopia: a study of the foundations of critical theory. New York: Columbia University Press, 1986, p. 340-341.

${ }^{120}$ Benhabib.S. "Sexual Differences and Collective Identities", in Signs, Winter, 1999, p. 343, nota 13 Ver também Benhabib, S. "The generalized and the concrete Other" in Situating the Self,: Gender, Community and Postmodernism in contemporary ethics, 1992, p. 251 e Benhabib, S. Critique, norm and utopia,...p.342.
} 
diferença de gênero é intimamente limitada pelo poder, porque todos os sistemas de gênero-sexo funcionam para explorar e oprimir as mulheres, então faz sentido pensar no poder como algo que apenas estrutura as opções disponíveis, quando estamos construindo nossas histórias de vida que já têm um gênero ("gendered life stories"); Sem dúvida o poder faz isso também, mas ele também não atinge o self mais profundamente do que isso, estruturando o próprio "eu” que escolhe como desempenhar o gênero? ${ }^{122}$

Allen sustenta que Benhabib não leva em conta que antes de articularmos a resposta à pergunta "quem é você?" já nos foi atribuído um gênero. Ela recorre a pesquisas empíricas de psicologia comportamental para justificar sua oposição a Benhabib. Esses estudos, diz Allen, indicam que o gênero se torna um elemento relevante do self muito cedo. Algumas pesquisas sustentam que aos dois anos as crianças começam a distinguir figuras femininas de masculinas e se auto-definem como meninos e meninas. Outras concluem que isso ocorre até antes disso, porque os adultos interagem e interpretam as mesmas reações de bebês meninos e meninas de modo distinto. Em qualquer caso, as identidades de gênero já nos são atribuídas muito antes de adquirimos a capacidade de narrar nossa própria história, ou seja, de desenvolvermos a habilidade que Benhabib julga necessária para constituirmos nosso self ${ }^{123}$.

No entanto, a crítica de Allen a Benhabib não parece correta. Em Benhabib, desde o nascimento estamos em uma teia de relações humanas, que já existia antes de nossa chegada. Nessa teia, os valores, a tradição e os critérios para distribuição dos papéis sociais já estão postos, inclusive os critérios para definir a identidade de gênero.

Nós só vamos nos engajar no processo de reconstruir, de ressignificar esses papéis, depois de desenvolvermos a habilidade de narrar nossa história de vida. Mas nós não iniciamos essa narração de um ponto neutro. Quando respondemos à pergunta “quem é você?”, nossa resposta já anunciará uma identidade de gênero.

Da idéia de que o núcleo do self está na capacidade de narrar não decorre que essa capacidade esteja primeiro desenvolvida para depois escolhermos as identidades

\footnotetext{
${ }^{121}$ Benhabib, S. “ Sexual Differences and Collective Identities”.., p. 348.

${ }^{122}$ Allen, Amy. The politics of our selves: Power, Autonomy and Gender in Contemporary Critical Theory. New York: Columbia University Press, 2008, p. 165.

${ }^{123}$ Idem, PP. 166-167.
} 
disponíveis em nossas redes de interlocução. Significa apenas que nossa capacidade de questionar e ressignificar essas identidades exige essa habilidade. Esse questionamento, porém, não é feito por um self descontextualizado. É feito por um sujeito que está desde o seu nascimento físico imerso em redes de interlocução que lhe atribuem papéis sociais. E o primeiro deles, diz Benhabib, está relacionado ao gênero ${ }^{124}$.

\section{III) Butler e a Crítica como virtude}

Em artigo intitulado "What is Critique? An essay on Foucault's virtue", Butler responde às acusações mais comuns à concepção de crítica de Foucault, da qual extrai sua própria noção de crítica. O título do artigo causa certa perplexidade, já que Focault é conhecido por defender uma moral anti-fundacionista e não prescritiva, ou seja, uma moral que não esteja fundamentada em uma determinada ética filosófica e que não conduza a conclusões sobre como dever ser a ação humana correta ou justa ${ }^{125}$.

Seguindo Nietzsche, Foucault salienta que é preciso questionar as certezas epistemológicas que definem o bom e o mau. Confiar em certezas sobre como o mundo deve ser reprime a crítica, uma vez que essas certezas nada mais são do que formas de oprimir modos diferentes de pensar. A crítica, portanto, exige que se vá além da ética filosófica. Mas “como é possível saber se é bom pensar de um modo diferente, se não soubermos que isso levará a um mundo melhor?"126.

Esse é o impasse que a teoria crítica deve enfrentar, diz Butler. Precisamos pensar a crítica como um questionamento aos nossos modos de conhecer mais consolidados. A necessidade desse questionamento deve-se a uma crise no campo epistemológico, que emergiu do debate entre visões normativas fortes e a teoria crítica $^{127}$.

\footnotetext{
${ }^{124}$ Benhabib explicita essa idéia quando trata do reconhecimento. Ela busca em teorias psicanalíticas respostas sobre o impacto que as relações do bebê com a pessoa responsável por seus cuidados têm na constituição da identidade de gênero. Essa questão será discutida mais detalhadamente no capítulo 4.

${ }^{125}$ Butler. What is critique? An Essay on Foucault's Virtue, p. 1;

${ }^{126}$ Butler, What is critique.., p. 4

${ }^{127}$ Idem, p. 5
} 
A crítica está associada à racionalidade moderna, em particular ao pensamento de Kant. Em Kant, a razão é condição para julgar e agir; o conhecimento é o caminho da emancipação. Sua questão central é: "você sabe até onde pode saber? Ao reconhecer os limites do conhecimento se terá feito do próprio conhecimento uma idéia justa, idéia esta que irá condicionar a obediência à autoridade. Obediência, assim, será uma subordinação refletida e não imposta ${ }^{128}$.

Na Alemanha, porém, a esquerda hegeliana e a Escola de Frankfurt formularam contundentes críticas ao positivismo e ao vínculo entre saber e liberdade, explicitando a correlação entre objetivação da ciência e a ocultação ou naturalização das formas de dominação próprias da sociedade contemporânea ${ }^{129}$.

A relação entre saber e poder, e não de saber e autonomia (como em Kant), é o ponto de partida da crítica em Foucault. Seu propósito é explicitar a impossibilidade de distinguir conhecimento de poder. É tratá-los como sinônimos ${ }^{130}$. Para ele, não reconhecer a imbricação entre racionalização e dominação é ao mesmo tempo ingênuo e perigoso. O campo de concentração é um exemplo extremo dos perigos da racionalização do poder, mas não é o único. Ao contrário, Foucault enfatiza a relação entre política e racionalização em todas as relações de poder no ocidente desde a modernidade. Confiar na razão como meio de legitimação do poder conduz a uma subordinação irrefletida à autoridade da razão ${ }^{131}$.

A crítica em Foucault e em Butler é menos ambiciosa do que a crítica kantiana, pois não busca a estrutura formal de validade universal. Ela consiste numa investigação histórica dos eventos que nos constituíram a partir da análise dos discursos que articulam o que pensamos, dizemos e fazemos. Não é, portanto, uma crítica transcendental. Sua proposta é, a partir da observação empírica do contexto que nos rodeia, analisar o nexo saber-poder, que sustenta aquilo que é aceito. Identifica-se, assim, o que é aceito para então reconstituir o trajeto que o tornou aceitável. Não

\footnotetext{
${ }^{128}$ Idem, p. $11 .$.

${ }^{129}$ Idem, p. 12

${ }^{130}$ Rabinow, "Introduction” in Foucault reader, p. 12

${ }^{131}$ Idem.
} 
aceitável em geral, mas apenas na localidade específica, que é objeto da observação empírica $^{132}$.

A crítica em Foucault busca restituir as condições de surgimento da singularidade das identidades aceitas. Essa singularidade, porém, não é deduzida da natureza das coisas, mas sim das condições concretas que lhe originaram. Essa crítica não requer um fundamento primário ou totalizante, pois ela não excede um contexto delimitado. Segundo Foucault, essa é a única "transgressão possível”. Cito:

"Eu prefiro as transformações específicas que provaram ser possíveis nos últimos vinte anos em um certo número de áreas referentes às nossas formas de viver e pensar, relações com a autoridade, relações entre os sexos, como identificar a insanidade e a doença; eu prefiro essas transformações parciais que foram feitas em correlação com análises históricas e a atitudes práticas, a programas sobre o novo homem que os piores sistemas políticos repetiram ao longo do século vinte"133.

Apesar de o projeto crítico dever permanecer fragmentado, isso não significa que Foucault recuse qualquer generalização. Mas essa generalidade não requer uma continuidade metahistórica através do tempo; o geral aqui está no estudo de modos de problematização, no estudo de questões de relevância geral em sua forma historicamente particular ${ }^{134}$.

A primeira tarefa da crítica é descrever o nexo poder-conhecimento em um determinado contexto para compreender o que constitui os modos de existir que são aceitos. A segunda tarefa é identificar os pontos de descontinuidade, as fissuras de um regime de verdade, e assim apontar os momentos em que o questionamento do sistema emerge ou pode emergir. Em resumo: a crítica tem duas tarefas. Uma delas é analisar as condições que constituíram um determinado regime de verdade. A segunda é apontar os limites dessas condições, ou seja, identificar os momentos em que há a oportunidade de transformação nesses regimes ${ }^{135}$.

\footnotetext{
${ }^{132}$ Foucault. "What is enlightenment" in Rabinow, Paulo The Foucault Reader. England: Penguin Books, 1984, p. 45

${ }^{133}$ Foucault. What is Enlightenment.., pp. 46 e 47

134 Idem

${ }^{135}$ Butler, What is critique...ip. 14.
} 
A crítica começa com a pressuposição de que a regra disciplinar falha em controlar e subjugar totalmente o sujeito. É o próprio sujeito que delimita seu self, mas essa delimitação é condicionada por normas que já existem. Embora a constituição do sujeito seja uma auto-formação, ela ocorre de acordo com modos de subjetificação que definem quais são as identidades socialmente viáveis. Enfim, em Foucault, a autoformação do self ocorre segundo as normas disciplinares, que viabilizam sua formação ${ }^{136}$. O self é compelido por essas normas a formar a si mesmo. Ele é compelido a agir, mas é claro, a agir conforme a norma. Resta saber porque agimos contra a norma.

Essa questão remete Foucault à origem da vontade de resistir. A insubordinação voluntária, diz Foucault, envolve algo "como" uma liberdade originária. Mas essa liberdade aparece como uma conjectura e não como fundamento da resistência. O uso da expressão “liberdade originária' por Foucault é, segundo Butler, uma manifestação de crítica como virtude. Cito:

“ O gesto de Foucault [de usar a expressão 'liberdade originária] é muito corajoso (...) porque ele sabe que não deve fundamentar a crítica na liberdade originária. Saber que não pode fazer isso, permite o seu uso particular em seu próprio discurso. Mas ainda assim ele enfrenta essa situação (...) e a torna uma alegoria para assumir o risco, que existe no limite do campo epistemológico. E isso se torna uma prática da virtude, talvez, e não, como dizem seus críticos, um sinal de desespero moral, precisamente porque práticas desse tipo de fala colocam um valor que não tem como ser fundamentado ou assegurado por si mesmo, coloca de qualquer forma, e assim mostra que uma certa inteligibilidade excede os limites da inteligibilidade que o poder-conhecimento já estabeleceu. Essa é a virtude em seu sentido mínimo porque oferece a perspectiva pela qual o sujeito ganha uma distância crítica em relação à autoridade estabelecida. Mas é também um ato de coragem, é agir sem garantias, arriscando o sujeito até as últimas conseqüências. "137

A "estranha forma de virtude", como diz Butler, que Foucault apresenta, não requer um fundamento filosófico. O sujeito não é primeiro formado pela norma para

\footnotetext{
${ }^{136}$ Idem, p. 19

${ }^{137}$ Butler, What is critique.., p. 18
} 
então formar a sim mesmo. O processo de auto-formação e de formação do sujeito pela norma ocorre simultaneamente num processo que nunca termina ${ }^{138}$.

A crítica, enfim, é uma virtude porque com ela o sujeito não se arrisca apenas a ser punido, ele arrisca sua própria existência social. Ela está diretamente ligada ao processo de dessubjetificação. A desubjugação acontece no momento em que um modo de existência é posto em risco para abrir espaço para um modo de existência que não é previsto pela regra disciplinar $^{139}$.

O trajeto rumo à crítica social não passa pela racionalização, nem está fundamentado num princípio universal. É um trajeto traçado pela pluralização infinita dos grandes conceitos, fruto de relações de dominação, que têm autoridade de conhecimento. Essa pluralização é obtida por um tipo de análise que Foucault denomina 'histórico-filosófica'. Ela é histórica porque consiste numa análise dos conteúdos históricos nos quais estamos inseridos, mas é filosófica porque desloca os habituais objetos da história para o problema do sujeito e do conhecimento. O resultado disso, enfim, é desnaturalizar as "verdades" de cada contexto e assim explicitar sua fragilidade ${ }^{140}$.

A pluralização da identidade de gênero, diz Butler, resulta do cumprimento da regra da heterossexualidade de uma maneira que evidencia as várias combinações possíveis entre sexualidade, identidade e comportamento. Desse modo, revela-se que a estrutura binária da identidade de gênero (feminino-masculino) não é uma decorrência da natureza. É o produto de relações de poder em um dado tempo histórico, no qual a heterossexualidade tem um papel político ${ }^{141}$.

Butler encontra um exemplo de desconstrução da identidade de gênero no filme "Boys don't cry". Aqui, a identidade de gênero aparece como algo instável e

\footnotetext{
${ }^{138138}$ Butler. Whatis critique... P, 18 .

${ }^{139}$ Butler, What is critique.., p. 3 .

${ }^{140}$ Foucault, M. Qu'est-ce que la Critique; Critique et Aufkärung. Bulletin de La Societé française de philosophie, Vol. 82, no 2, avr-juin 1990, (Conferência proferida em 27 de maio de 1978) Tradução de Gabriela Lafetá Borges, PP. 18 e ss.

${ }^{141}$ Butler, j. Gender Trouble: Feminism and the Subversion of Identity. New York and London, 2007 (5a edição), p. 43 e ss.
} 
perturbador, porque é na fluidez da fronteiras entre o masculino e o feminino que está a identidade da personagem central da narrativa ${ }^{142}$.

O filme conta a história de Brandon, uma mulher travestida de homem, cuja identidade feminina permanece em segredo. Ele (a) quer ser reconhecido (a) como homem em todos os aspectos. Brandon quer deixar sua condição de mulher para ser um homem heterossexual. Essa identificação, no entanto, vacila em muitos momentos, como quando ela precisa usar e descartar um absorvente higiênico sem deixar nenhum vestígio. Mas logo em seguida, Brandon recupera a personagem do homem heterossexual, embora nunca em caráter definitivo. A cada dia, Brandon precisa recriar sua fantasia, de modo que ela se torne verossímil para si mesmo (a) e para os outros ${ }^{143}$.

A menina por quem Brandon se apaixona também tem um comportamento inusitado. Inicialmente, ela aparenta não saber que Brandon é uma mulher, mas esse não saber é parte de seu próprio fetiche de desejar um "homem feminino". Às vezes, ela diz que não sabe e às vezes que sabe, mas em nenhum dos casos fica realmente claro se ela está falando sério. Quando Brandon e essa menina têm sua primeira relação sexual, a ambigüidade é, surpreendentemente, afastada. O corpo é feminino, mas a fantasia da amante de Brandon é a de estar fazendo sexo com um homem. Brandon "faz sexo como homem", usando um pênis de borracha, apesar da nudez que revela o corpo feminino ${ }^{144}$.

A relação "heterossexual" de Brandon com uma mulher é o que consagra sua identidade masculina. Ao cumprir o papel masculino plenamente em um corpo anatomicamente feminino, Brandon coloca em dúvida a essência do masculino. Sua dessubjetificação, porém, não diz respeito apenas a si mesmo (a). Ela atinge a subjetificação dos homens em geral. Que certeza os homens podem ter de sua masculinidade depois de uma mulher representá-la tão bem?

Quando, finalmente, a identidade feminina de Brandon é revelada, a reação dos homens, seus amigos, é violenta. Para colocar Brandon em seu "devido lugar de mulher", eles se reúnem para estuprá-la. Assim, eles afastam as ambigüidades que Brandon havia exposto e restituem a coerência dos papéis do homem e da mulher ${ }^{145}$.

\footnotetext{
${ }^{142}$ Butler. "Longing for recognition" in Undoing Gender. New York and London, 2004, p. 142-143.

143 Idem.

144 Idem.

145 Idem.
} 
A questão de Butler é: Brandon é um rapaz, uma mulher ou uma lésbica? Nenhuma dessas categorias descreve adequadamente o comportamento e os desejos de Brandon. $\mathrm{O}$ fato de ele (a) ter de construir sua identidade como homem não é uma particularidade de sua condição. Todo homem constrói sua masculinidade diariamente comportando-se como homem. Sua identidade de gênero não está assegurada pela anatomia. Para ser homem, é preciso agir como homem ${ }^{146}$.

Butler cogita também a possibilidade de Brandon ter assumido a identidade masculina porque é lésbica e quer fazer sexo com mulheres sem arcar com o ônus social da homossexualidade. No entanto, diz ela, isso significaria assumir que o gênero está a serviço da sexualidade, negando assim os prazeres que acompanham o processo de identificação. Ser um homem para Brandon é um prazer em si mesmo, por isso não é simples caracterizá-lo (a) como ou apenas uma lésbica ${ }^{147}$.

Enfim, a confusão nas identidades de gênero que Brandon provoca é um exemplo de crítica por dessubjetificação. A dificuldade em encaixá-lo (a) em qualquer categoria explicita as incompletudes e incoerências das identidades. Brandon enfrenta essa situação em nome do prazer, da liberdade perturbadora de confundir essas categorias $^{148}$.

No entanto, o estupro mostra o quanto é perigoso exercer essa liberdade. A ameaça da confusão de identidades, tão profundamente ligadas ao self, como a identidade de gênero, provoca reações violentas. A necessidade de recompor a ordem e a coerência, que atribui a todos o seu lugar no mundo, foi a motivação do estupro.

Mas se a identidade masculina não era apenas um instrumento para exercer sua sexualidade sem transgredir o sistema de gênero, então por que Brandon assumiu o risco de ficar sem categoria, sem identidade? O prazer da crítica pela dessubjetificação não cobra um preço alto demais?

\footnotetext{
146 Idem, p. 143.

${ }^{147}$ Idem, p. 144.

${ }^{148}$ Idem
} 


\section{IV) Contextualização do sujeito e capacidade crítica}

A resistência é possível mesmo depois da contextualização do sujeito. Tanto Benhabib como Butler apresentam concepções de sujeito em que o contexto histórico, social e cultural condiciona e limita a formação do sujeito e sua autonomia. Mas em nenhuma delas essa limitação é total.

No entanto, o grau dessa limitação é muito maior em Butler do que em Benhabib. Sua concepção de crítica está atrelada à idéia de Foucault de que somos “produzidos pelo poder". Isso significa que o poder define o modo de subversão possível. Como o poder está em toda parte, não há nenhum espaço em que a regra disciplinar não incida. Por isso a crítica se realiza pelo cumprimento da regra. Não há como ir além dela. É na própria regra que oprime que está a possibilidade da crítica.

Esse modo de conceber a crítica é mais limitado por duas razões. Primeiro porque ao identificar a crítica com o processo inverso da subjetificação, Butler equipara a transformação social a uma reorganização das relações de poder. Ao mesmo tempo em que a crítica desconstrói as relações de poder vigente, ela inaugura novas assimetrias. A dessubjetificação de uma regra resulta numa nova regra de subjetificação. Essa nova regra disciplinar, como a anterior, leva à subordinação. A ressignificação da regra disciplinar hegemônica não é movida pela busca pela superação da subordinação. Não há um horizonte de igualdade que motive a crítica.

Em segundo lugar, porque localiza a resistência no comportamento individual. No exemplo do filme "Boys Don't Cry" isso fica claro. O questionamento da regra da heterossexualidade se dá pelo comportamento de Brandon. É ele (a) que a enfrenta e arca sozinho (a) com o ônus da inadequação social. Isso sugere que a preocupação de Butler em evitar generalizações excludentes apresenta dificuldades para justificar a crítica como ação coletiva.

Benhabib, por sua vez, constrói uma concepção de self profundamente enraizada em redes de interlocução, a ponto de alguns aspectos de sua concepção de crítica assemelharem-se à de Butler. No exemplo das meninas muçulmanas na França, isso fica claro. A crítica das meninas muçulmanas não se deu pelo enfrentamento da regra disciplinar, que lhes obriga a usar o véu. A crítica se realizou pelo cumprimento da 
regra, mas de uma maneira que transforma um símbolo cultural de exclusão e opressão da cultura islâmica em símbolo de crítica à sua exclusão na sociedade francesa.

Essa semelhança também aparece quando Benhabib critica Charles Taylor. Aqui ela deixa claro que no self não há nada que seja definitivo. Não há uma moralidade herdada do contexto, que seja inseparável da personalidade de cada indivíduo. A identidade é fruto da narração constante que revê as normas e os valores indefinidamente.

O self, enfim, constitui-se pelo diálogo. O diálogo, por sua vez, é condicionado tanto pela igualdade como pela diferença entre os interlocutores. A capacidade de assumir a perspectiva dos demais participantes da rede de interlocutores se traduz na possibilidade do distanciamento dos contextos em que estamos imersos. Nós fazemos isso, assumindo o ponto de vista do "outro" com quem dialogamos, bem como o do “outro generalizado", ou seja, pela adoção do ponto de vista universalista. Assim, em Benhabib, mesmo o sujeito formado pelas redes de interlocução pode avaliar os valores de seu próprio meio de um ponto de vista externo a seu self e a seu contexto.

Benhabib, portanto, tem uma concepção mais forte de autonomia porque admite a possibilidade de distanciamento dos contextos em que estamos imersos. Isso, porém, não implica a retomada do sujeito abstrato, conforme pensa Butler. Seu argumento é o de que podemos e precisamos assumir outras perspectivas além da nossa própria, para construirmos nossa identidade. Como a identidade é uma construção coletiva que se dá por meio do diálogo, precisamos nos esforçar para compreender o outro e desenvolvermos uma visão abrangente das expectativas dos interlocutores. Do contrário, não há ação discursiva, e a construção e a continuidade de nossa própria existência são comprometidas.

Enfim, nem Butler está correta quando afirma que Benhabib negligencia a contextualização em nome da autonomia, e nem Benhabib tem razão em dizer que Butler elimina a capacidade crítica do sujeito em nome da contextualização. A tese de ambas concilia autonomia com contextualização do sujeito.

Até aqui o projeto de Fraser de conciliar os argumentos de Butler e Benhabib soa promissor. No entanto, as diferenças entre o self narrativo e o self performativo 
sugerem que suas divergências têm raízes profundas. Do processo de formação social do self em cada delas derivam modos distintos e entender a motivação da crítica.

A resposta à pergunta "por que resistimos à opressão?" está intimamente ligada à concepção de espaço social onde a identidade se forma. Num espaço assimétrico, como em Butler, o reconhecimento de uma dada identidade implicará a desvalorização de outra. Mas num espaço social em que a igualdade nas relações sociais aparece ao menos como uma possibilidade, o reconhecimento de uma identidade poderá abarcar a pluralidade entre os seres humanos. Por isso, o reconhecimento é um elemento fundamental para entender as divergências que estruturam o pensamento de Benhabib e Butler. O fim da polarização epistemológica na teoria feminista que Fraser propõe remete ao modo como Butler e Benhabib entendem o reconhecimento social. 


\section{CAPÍTULO III: Reconhecimento e Resistência}

Uma pesquisa feita com alunas de um seminário sobre "Estudos sobre mulheres" na Universidade de Cornell revelou que a maior parte das estudantes empenhava um esforço excessivo para atingir ou manter a magreza, e que um número significativo delas sofria distúrbios alimentares. Em seus depoimentos, todas afirmaram ter consciência de que estavam reproduzindo padrões de feminilidade que sabiam ser opressores, que tinham argumentos teóricos para contestá-los, mas que simplesmente não conseguiam controlar o impulso de segui-los. Disseram ainda que essa distância entre conhecimento e o impulso de subordinação lhes gerava culpa, porque sabiam estar reforçando as discriminações que pretendiam combater. Mas não podiam evitar a frustração por não conseguir atingir o padrão de excelência exigido pela cultura, o que gerava uma auto-rejeição que se manifestava como anorexia e bulimia. ${ }^{149}$.

Esse exemplo sugere que ainda que sejamos capazes de identificar as regras disciplinares que nos oprimem, temos muita dificuldade de nos rebelarmos contra elas. Isto ocorre porque, como dizem Butler e Foucault, o poder não é apenas uma força externa que nos oprime, é também uma força que interiorizamos porque é ela que move a construção de nosso próprio self ${ }^{150}$.

Ao trazer Foucault para a teoria feminista, Butler enfatizou que as regra da feminilidade são ao mesmo tempo a fonte de opressão e de criação da identidade feminina. Essa criação não é feita de forma impositiva, uma vez que o próprio sujeito participa de seu processo de criação. Por isso, para Butler e Foucault, a idéia de que o sujeito emerge das relações de poder não é incompatível com a sua capacidade de agir. Ao contrário, sua capacidade de agir é condição de sua constituição.

No caso da identidade de gênero, a ação que produzirá a identidade deve reproduzir os comportamentos associados às regras da feminilidade e da masculinidade.

\footnotetext{
${ }^{149149}$ Brumberg, Joan Jacobs. The body project: an intimate history of American girls. New York: Vintage, 1997 (citado por Allen, Amy. The politics of ourselves: Power, Autonomy and Gender in Contemporary Critical Theory. New York, Columbia University Press, p. 181.

${ }^{150}$ Butler, J. The Psychic Life of Power: Theories in Subjection. Standford, CA: Standford University Press, 1997, p.1
} 
Ser mulher ou homem, portanto, é um atributo definido antes pelo comportamento feminino ou masculino do que pela distinção anatômica ${ }^{151}$.

Segundo Butler, o elemento crucial na identificação do masculino e do feminino é a orientação sexual. Ser mulher é, antes de mais nada, sentir desejo sexual por homens, e ser homem, sentir desejo por mulheres. Assim, a regra disciplinar fundamental da identidade sexual é a heterossexualidade. Essa regra é responsável tanto pela produção das identidades aceitas quanto das identidades “anormais”. O gay, a lésbica, os travestis e os transexuais são categorias criadas por força da mesma norma que constrói a categoria do homem e da mulher. É nesse sentido que Butler e Foucault afirmam que o poder é produtivo ${ }^{152}$.

Mas, além de produtivo, como foi dito, o poder é também opressivo. Mantém permanentemente acesa a ameaça da punição pelo descumprimento dos padrões. $\mathrm{O}$ receio de não exprimir a consistência entre anatomia, comportamento e desejo reprime os sujeitos porque estabelece rigorosamente o modo de agir socialmente aceito. Por isso, tanto em Butler como em Foucault, a identidade, qualquer que seja ela, é um rótulo que encarcera os sujeitos porque condiciona sua aceitação social ao cumprimento de normas que lhes impõem o dever de agir e pensar de determinado modo, sob pena de serem relegados à condição de párias sociais ${ }^{153}$.

O sujeito é, portanto, simultaneamente produzido e reprimido pelo poder. A identidade é o resultado da imposição da norma sobre o sujeito e do seu engajamento na sua reprodução. Se a norma é opressora, mas ao mesmo tempo é responsável pela criação da identidade, o preço da identidade é a subordinação. A construção da identidade, enfim, consiste num processo de auto-opressão. ${ }^{154}$.

Mas por que os sujeitos se auto-oprimem? Qual é a motivação para que as pessoas se submetam e assim ratifiquem padrões repressores ao invés de se rebelarem contra eles?

\footnotetext{
${ }^{151}$ Butler, Judith. Gender Trouble, p.34 e 198.

152 Bulter, Judith. Bodies That matter, pp. 23 e ss.

${ }^{153}$ Butler. Gender Trouble, p.24 e ss.. Ver também Foucualt, Michel. “ The Repressive Hypothesis”., p 326 e 327.

${ }^{154}$ Bulter, J.The Psychic Life of Power, 14.
} 
Butler afirma que Foucault não explora essa questão. Provavelmente, a sua rejeição à psicanálise conteve suas investigações sobre a dimensão psíquica do impulso de subordinação. Mas Butler afirma que para explicar a vontade de subordinação é preciso examinar a incidência do poder sobre a dimensão psíquica do ser humano ${ }^{155}$.

Em seu livro 'The psychic Life of Power”, Butler investiga as razões que levam o sujeito a desejar a submissão mesmo depois de as práticas opressoras terem sido desmistificadas racionalmente ${ }^{156}$. Ela traduz essa questão no seguinte problema: "Como o poder, que a princípio parece ser uma pressão externa, é introjetado em nossa psique a ponto de não conseguirmos evitar nossa submissão? Voltando às alunas de Cornell: Por que não conseguem escapar da regra da feminilidade $i$

A incorporação de Butler do modo de subjetificação de Foucault é chave para encontrar essa resposta. A fusão entre identidade e subordinação leva à conclusão de que a vontade de subordinação é uma conseqüência da necessidade de ter uma identidade. As alunas de Cornell preferem pagar o preço da regra da feminilidade a "não serem como uma mulher deve ser". O reconhecimento social estará condicionado ao cumprimento dessa regra, dessa subordinação. Assim, entre ser oprimido e não ser reconhecido, o sujeito irá escolher a opressão ${ }^{157}$.

Mas se a subordinação é condição de possibilidade da existência do sujeito, como serão possíveis a ação e a resistência¿ Há algo a fazer a respeito da subordinação quando o próprio oprimido corre voluntariamente ao encontro de sua opressão mesmo depois de reconhecê-la como tali

$\mathrm{O}$ argumento de Butler se diferencia da maioria das teses psicanalíticas sobre a origem da subordinação porque a resistência nasce no âmbito do próprio poder que ela irá afrontar. Isso implica conceber a resistência como uma forma de cumprir a regra disciplinar que se volta contra a própria regra. Esse modo de cumprir a regra requer o desejo de não ser o sujeito esperado pela norma. Por isso, Butler entende a crítica social como um processo de dessubjetificação, ou seja, como o processo inverso da produção do sujeito, o processo de desconstrução da identidade. A desconstrução é possível porque nenhuma regra disciplinar atinge a universalidade que pretende. Sempre

\footnotetext{
${ }^{155}$ Butler. The psychic life of power, p. 1 e ss.

${ }^{156}$ Idem, p; 62.
} 
subsistem as "anomalias" que indicam onde estão as fissuras e fragilidades dos padrões ${ }^{158}$.

A transexualidade é o exemplo paradigmático do sujeito crítico em Butler ${ }^{159}$. Afinal, o(a) transexual cumpre a regra disciplinar da feminilidade e da masculinidade de um modo que confunde a coerência entre desejo, comportamento e anatomia. E as possibilidades de combinações para transgressão da regra são infinitas. Corpos masculinos, comportamento feminino e desejo homossexual; corpos masculinos comportamento feminino e desejo heterossexual; corpos femininos, comportamentos femininos e desejo homossexual, corpos femininos, comportamento masculino e desejo heterossexual, e assim por diante.

O argumento deste capítulo é o de que a reflexão de Butler sobre a origem psíquica da subordinação contribui para o diagnóstico da recorrente e insistente subordinação das mulheres. Ajuda a explicar por que tantas estudantes de teoria feminista em Cornell sofrem de distúrbios alimentares. Exemplos como esse deixam claro que as dificuldades para uma crítica feminista não podem ser minimizadas. A desconstrução do gênero, a revelação dos jogos de interesse por trás das concepções de masculino e feminino, não é suficiente para que os sujeitos oprimidos se rebelem.

Denunciar a falácia do fundamento natural da identidade de gênero é sem dúvida um passo indispensável. No entanto, será preciso não apenas ter conhecimento disso. É preciso levar a sério a resistência das próprias mulheres para sair da situação de subordinação. É preciso reconhecer que essa resistência não resulta de mera má-fé ou comodismo. É uma resistência de sujeitos que lutam pela obtenção e estabilidade de seu reconhecimento social.

No entanto, Butler coloca dificuldades para explicar o processo inverso, ou seja, a resistência à subordinação. A relação necessária entre sujeito e sujeição coloca o indivíduo entre a escolha de se subordinar e ter reconhecimento social, e a de resistir e a de não ter reconhecimento social. Escolha difícil, senão impossível, caso se admita, como faz Butler, que temos uma pulsão narcisista de dar continuidade à nossa existência.

\footnotetext{
${ }^{157}$ Idem

${ }^{158}$ Idem, p. 100
} 
Em Benhabib e em Jessica Benjamim, porém, encontram-se os elementos que faltam a Butler: a intersubjetividade e a pluralidade. Assim, é possível admitir que "o outro" cumpre algum papel na construção do "eu". O reconhecimento pode assumir uma função constitutiva não apenas do eu, mas também do outro. A conseqüência disso é que a busca de modos diferentes de reconhecimento, ou seja, a busca de outras identidades, podem não levar ao desaparecimento do "self". A resistência, portanto, não é indissociável da autodestruição.

O objetivo deste capítulo é tratar da contribuição de Butler para explicar a vontade de subordinação humana, analisando a incidência do poder na dimensão psíquica. Em seguida, serão abordados os problemas que sua concepção de vontade de subordinação trazem para justificação da vontade de dessubordinação, ou seja, na motivação da resistência.

\section{I) Reconhecimento e dependência}

A vontade de subordinação, diz Butler, tem origem na dependência originária do bebê à pessoa responsável por seus cuidados. Na infância, o estabelecimento de vínculos é condição de nossa sobrevivência em sentido literal. Nessa fase, não importa se nos vinculamos a situações de subordinação ou não; apenas precisamos estabelecer esses vínculos para garantir nossa existência física ${ }^{160}$. Butler afirma que essa dependência inscreve na psique humana a relação entre reconhecimento e sobrevivência. Enquanto na infância o que está em jogo é a sobrevivência física, na fase adulta é a sobrevivência social ${ }^{161}$.

Butler exemplifica a relação entre identidade e subordinação aproveitando a concepção de “interpelação” de Althusser. A cena de Althusser é a seguinte: uma pessoa está andando na rua e um policial grita para ela: "Ei, você!" A questão de Butler é: por que nos voltamos para atender o chamado do policial, ou seja, por que o sujeito se submete à autoridade ${ }^{162}$ ?

\footnotetext{
${ }^{160}$ Allen, Amy, p. 81

${ }^{161}$ Butler, Judith. The psychic Life of power, p 100 e ss.

162 Butler, J. The Psychic Life of power, p. 108. Ver também Allen, A., p. 82.
} 
O medo de ser preso não é suficiente para explicar porque atendemos ao comando policial. Não se o poder for concebido como repressivo e produtivo como em Butler e Foucault. Nós atendemos ao comando do policial porque naquela relação é ele quem representa e exprime a regra disciplinar. Nós nos voltamos porque precisamos ser reconhecidos pela autoridade que define qual é a conduta adequada para nos encaixarmos no nosso papel social, ou seja, para termos uma identidade aceita ${ }^{163}$.

A dimensão produtiva do poder, porém, revela que essa submissão não é inescapável. A redução do poder à opressão é uma fantasia que, uma vez que seja desmascarada, abre caminho para a resistência, para uma dessubjetificação crítica. No exemplo da relação entre o indivíduo e o policial, a pulsão de se submeter à norma existe, mas pode ser contida. A pessoa pode escolher seguir em frente e ignorar a autoridade do policial, que ficará abalada justamente porque ela não é apenas imposta, ela deve ser confirmada e reproduzida pelo seu subordinado. No entanto, como o poder não é apenas repressivo, o que está em jogo quando o sujeito ignora o chamado do policial não é apenas o risco da punição, é a constituição da identidade do subordinado, bem como a da autoridade ${ }^{164}$.

A subordinação na construção da identidade de gênero se dá pela imposição de padrões de comportamento rigorosos que permanecem abrigados na psique humana desde muito cedo. Butler parte da concepção de “melancolia” em Freud para explicar como esse processo de introjeção da norma ocorre.

A melancolia é o processo contínuo de luto pela perda de um objeto. Como o luto é contínuo, a vinculação com o objeto perdido também é ${ }^{165}$. O sentimento de perda torna-se assim permanente e se instala na psique humana através do processo de identificação. Assim, o objeto perdido é preservado como parte da própria psique. Nós nos identificamos com o objeto apesar de o termos perdido. É isso que Freud chama de identificação regressiva ${ }^{166}$.

\footnotetext{
163 Idem.

${ }^{164}$ Allen, Amy, p. 78 e ss.

165 Allen, Amy, The politics of ourselves, p. 78.

${ }^{166}$ Butler, Judith. The Psychic Life of power.., p. 133
} 
Da concepção de melancolia em Freud, diz Butler, resulta um ego formado pelo luto dos objetos amados e perdidos, que jamais é superado. Esse luto, porém, permanece latente e reprimido pelo superego.

A primeira melancolia, segundo Freud, vem do complexo de Édipo ou de Electra. O desejo do filho pela mãe ou da filha pelo pai é o ponto de partida para a formação da identidade de gênero. Mesmo depois da assimilação do tabu do incesto à psique, o luto pela perda da possibilidade desse desejo permanece no ego, mas o superego cumprirá a função de proibir o lamento pela perda ${ }^{167}$.

Butler aproveita a identificação regressiva freudiana para interpretar a identidade de gênero. Ela afirma que a identidade "masculina" e "feminina" são estabelecidas através de proibições que impõem a perda de determinadas formas de viver a sexualidade e que reprimem o luto por essa perda ${ }^{168}$.

O objeto perdido no campo da identidade de gênero é a impossibilidade da homossexualidade, que passa a ser vivida como algo tão inviável quanto o incesto, e cuja perda não se pode nem lamentar. A conseqüência disso é que essa forma de conceber a identidade de gênero imprime nelas a marca da melancolia ${ }^{169}$.

Uma identidade de gênero coerente, que é indispensável para o reconhecimento social, pressupõe o cumprimento da regra da heterossexualidade. Ter o direito a uma identidade de gênero implica reprimir a melancolia da homossexualidade. Por isso, os vínculos homossexuais não apenas transgridem a norma da heteronormatividade, eles têm o poder de corroer a identidade do sujeito. Isso explica porque a homossexualidade provoca reações tão violentas do superego, que muitas vezes se manifestam em agressões gratuitas contra homo e transexuais. A ameaça que representam não é externa, é interna. Trazem à tona a possibilidade que retomar o objeto perdido, mas um objeto de cuja repressão e esquecimento depende o reconhecimento social ${ }^{170}$.

Mas por que as pessoas assumem tamanho risco? Precisamos ser heróis ou autodestrutivos para criticar a norma disciplinar? Embora Butler jamais responda a isso

\footnotetext{
${ }^{167}$ Idem

168 Allen, Amy, The politics of ourselves, p. 180

${ }^{169}$ Idem, p. 79

${ }^{170}$ Allen, Amy. The politics of ourselves.., p. 80. Ver também cap. 2 sobre a personagem Brandon do filme "boys don't cry"
} 
textualmente, sua tese sugere que sua resposta seria afirmativa. Afinal, Butler estabelece uma relação necessária entre dependência, subordinação e subjetificação. Ela não contempla a possibilidade de a dependência não levar à subordinação. Em seu argumento, não há qualquer referência a situações em que a dependência é recíproca; tampouco há referências a gradações nos níveis de subordinação ${ }^{171}$. Ter uma identidade é algo que buscamos apaixonadamente, por isso participamos ativamente do processo de subjetificação. No entanto, como a identidade é sempre uma forma de criar padrões à custa das complexidades do self, a sua construção implicará a repressão dessas complexidades. Por isso, o processo de sujetificação leva, inevitavelmente, à subordinação.

Sua concepção de crítica, porém, sugere uma certa ambigüidade em relação a isso. A crítica implica o engajamento no processo dessubjetificação, ou seja, implica a adoção da identidade incoerente, como no caso do transexual ${ }^{172}$. O raciocínio de Butler leva à conclusão de que a crítica exige do sujeito que ele se desvincule da sua vontade de ser sujeito ${ }^{173}$, no entanto isso é incompatível com seu argumento de que a necessidade de reconhecimento social nos leva a pagar o preço cobrado pela identidade: a subordinação. Se a subjetificação é condição de nossa existência social, como diz Butler, a dessubjetificação é uma espécie de suicídio social $_{\dot{\zeta}}{ }^{174}$.

A saída desse impasse está na distinção entre dependência e subordinação. Desse modo, passa a ser possível aventar a possibilidade de a subjetificação não levar sempre à subordinação. Para isso é preciso contemplar modos de reconhecimento que não levem sempre à destruição da diferença ${ }^{175}$.

Falta a Butler uma distinção normativa entre formas melhores e piores de subjetificação. Sem isso a possibilidade da resistência supõe que o sujeito arrisca toda a

\footnotetext{
${ }^{171}$ Idem

${ }^{173}$ Butler, Judith. "Bodies and power revisited" in Feminism and the Final Foucault . Taylor, Dianna and Vintage, Karen (ed). Champaign: University of Illinoies, 2004, p 191.

${ }^{174}$ Fraser, N. Foucault on modern power. New York and London: Routledge, 2004. Ver também Allen, Amy, p.

${ }^{175}$ Idem, p.69
} 
sua possibilidade de ser reconhecido socialmente ${ }^{176}$. Para isso é preciso introduzir a concepção de "reconhecimento mútuo", que Butler, explicitamente, descarta ${ }^{177}$.

Em trabalhos posteriores a "The pshychic life of Power", Butler parece compreender o impasse que a equiparação entre dependência, subordinação e reconhecimento gera para a motivação da resistência. Em "Bodies and Power Revisited", ela menciona a possibilidade de modos de subjetificação mais e menos opressores. No entanto, ela afirma que a luta por práticas de subjetififcação menos opressoras leva à perda de reconhecimento social. Fica faltando ainda, em Butler, admitir que práticas melhores de sujetificação possam ter também uma dimensão construtiva, ou seja, que não levem sempre à exclusão ${ }^{178}$.

No entanto, o argumento de Butler revela-se ambivalente porque ela explicitamente sustenta que negar reconhecimento aos excluídos pela regra disciplinar é algo ruim. As acusações que dirige à segunda onda do feminismo são focadas no problema da exclusão ${ }^{179}$. Quando trata da heteronormatividade ela também deixa claro que a opressão a outras orientações sexuais é algo reprovável. No entanto, sem uma concepção de reconhecimento que tenha uma face construtiva do self, não há como justificar sua crítica à exclusão. Para dizer que a exclusão é ruim, ela precisa de uma concepção de inclusão boa, que não tem espaço em seu argumento ${ }^{180}$.

Em "Giving na Account of Oneself”, ela dá um passo nessa direção. Ela parte da dependência originária, como em "The psychic Life of Power", mas aqui ela estabelece a distinção entre dependência e subordinação. Ela distingue tipos de dependência que comprometem o reconhecimento e a dependência relacional que nos mantém tanto física quando psiquicamente ${ }^{181}$. Essa distinção implica reconhecer duas dimensões do self. A que está no nível mais íntimo é a dimensão relacional do nosso "eu", sempre dirigido a um "outro"; e a outra dimensão do self é voltada para fora, para as normas culturais e as relações de poder que definem aquilo que podemos $\operatorname{ser}^{182}$.

\footnotetext{
${ }^{176}$ Idem.

${ }^{177}$ Butler, Judith. “ Longing for recognition” in Undoing gender p. 134.

${ }^{178}$ Butler, Judith. " Bodies and power revisited”, pp. 191 e ss.

${ }^{179}$ Butler, Judith. Gender Trouble..., p. 194.

180 Benjamim, J. “ The Shadow of the other" in Constellations. Volume 1, no 2, 1994, pp. 236 e ss.

${ }^{181}$ Butler, Judith. " Giving na account of oneself”, cap. 1

182 Idem
} 
A introdução da dimensão relacional do self traz conseqüências diretas na concepção de reconhecimento em Butler. Ela passa a admitir que a luta por reconhecimento ocorre através de intercâmbios recíprocos, passa a admitir, enfim, a intersubjetividade no processo de formação da identidade ${ }^{183}$.

Butler reinterpreta a dependência como interdependência, abrindo caminho para a possibilidade do reconhecimento mútuo. Essa mudança sugere que Butler tenha passado a admitir uma reorientação normativa da política. Ela reforça essa suspeita quando afirma que a promoção de formas não subordinadoras ou menos subordinadoras de reconhecimento é uma obrigação ética ${ }^{184}$. Com essa afirmação, Butler finalmente desvencilha subordinação de reconhecimento e sugere uma concepção de inclusão. Afinal, sua tese aqui sugere que há modos de reconhecimento do "outro" que não levam obrigatoriamente à destruição do "eu". A identidade pode, enfim, não ser necessariamente e apenas excludente; pode ser também inclusiva. ${ }^{185}$

No entanto, Butler recuou logo depois. Em seu ensaio "Longing for recognition", ela critica Jessica Benjamim justamente em função da sua concepção de reconhecimento intersubjetivo ${ }^{186}$. Ela afirma que embora Benjamim aceite a idéia de que o reconhecimento pode ser opressor, ela mantém um ideal de reconhecimento em que a opressão não lhe é um traço inescapável; é apenas uma distorção que pode e deve ser combatida e superada ${ }^{187}$. A objeção que Butler faz a Benjamim mostra que ela retoma a posição que defendeu em "The Phsychic life of Power" sobre a impossibilidade de o reconhecimento não ser opressor e, portanto, de a identidade não resultar sempre em exclusão. Com isso, ela reincorpora à sua tese as inconsistências que havia tentado afastar em "Giving an account of oneself". Butler se vê novamente com dificuldades para explicar a motivação da resistência.

A interpretação que Butler faz de J. Benjamim a leva a concluir que Benjamim pressupõe a possibilidade de um espaço intersubjetivo que é livre de opressão, um espaço igualitário. Ela afirma, retomando Foucault, que confiar nisso é perigoso porque a destruição do outro é inerente à intersubjetividade. Assim, o reconhecimento mútuo

\footnotetext{
${ }^{183}$ Idem, p. 44

${ }^{184} \mathrm{Idem}$, p. 28 e ss.

${ }^{185}$ Butler, Judith. “ Longing for recognition” .., p. 134

186 Idem

${ }^{187}$ Idem
} 
não passa de uma regra disciplinar que cria fantasia da simetria de poder que esconde as exclusões que determina. Por isso ela conclui que afastar o caráter subordinador do reconhecimento é uma ilusão. Mas não uma ilusão ingênua. É uma ilusão que funciona como forma de criar e reforçar exclusões ${ }^{188}$.

Butler se opõe à intersubjetividade porque considera que a existência do "eu" exige a absorção do "outro". A construção da identidade do "eu" implica a destruição da diferença, porque ela ameaça a coerência e estabilidade do self. Assim, as certezas sobre a identidade são colocadas em xeque. O reconhecimento do 'eu", enfim, depende do sacrifício do outro. Este último somente poderá subsistir como o objeto perdido e reprimido.

Trazendo esse argumento para a questão de gênero, Butler afirma que o reconhecimento mútuo leva à afirmação da identidade masculina como o pólo positivo, e a construção do feminino como o contrário do masculino. A via não é de mão dupla. A mulher funciona como o diferente que confirma a identidade masculina. Simone de Beauvoir já havia alertado para isso, mas Butler sustenta que é preciso introduzir ainda outros pólos na identidade de gênero. O homo e o transexual não são definidos por negação ao masculino, como a mulher. Eles(as) simplesmente, não podem ser definidos. O reconhecimento mútuo, portanto, não deixa espaço para a pluralidade dos modos de existir e, neste caso, de viver a sexualidade ${ }^{189}$.

Entretanto, essa interpretação do reconhecimento mútuo não faz justiça ao pensamento de Benjamim. Ao contrário do que diz Butler, ela não descarta o risco de destruição contínua como algo inerente ao reconhecimento ${ }^{190}$. Como Butler, ela afirma que o reconhecimento exige do sujeito a recusa do outro, a negação do que é diferente. Assim, o ideal de reconhecimento pelo qual lutamos, jamais afasta seu caráter destruidor. Mas em Benjamim, esse ideal mantém uma tensão entre construção e destruição.

A introdução da dimensão da construção, ou da inclusão, no reconhecimento permite a Benjamim abrir espaço para o reconhecimento mútuo. No entanto, o fato de

\footnotetext{
188 Idem, p. 147

${ }^{189}$ Butler, Judith. “Longing for recognition”, pp. 134 e ss.

${ }^{190}$ Benjamim, Jessica. Like subjects, like objects: essays on recognition and sexual difference. New Haven and London: Yale University Press, p. 24
} 
aceitar também a dimensão destrutiva do reconhecimento, de negação da diferença, faz com que admita que as relações intersubjetivas são também permeadas pelo poder e por assimetrias. Mas ela afirma que as tensões e os conflitos de interesses não eliminam a possibilidade de reconhecimento do outro. O reconhecimento, enfim, é ao mesmo tempo construtivo e destrutivo ${ }^{191}$.

A tese de Benjamim denuncia a falta de dinamismo nas relações humanas em Butler. Afinal, para Butler, o reconhecimento sempre é apenas uma forma de encobrir o caráter destruidor (do outro) inscrito na psique humana. Por isso o "outro" aparece sempre como uma ameaça. Para superar a concepção estática de reconhecimento, Butler teria que ampliar o foco de sua análise para abarcar o outro lado da tensão entre reconhecimento e destruição. A existência do outro ameaça a nossa própria existência, mas é também através da relação com o outro que nosso self é construído. Enfim, a intersubjetividade reúne a destruição e a construção como os dois lados do reconhecimento $^{192}$.

Curiosamente, a tese de Butler sobre reconhecimento culmina no isolamento do sujeito, pois o outro com quem nos relacionamos existe apenas no nível intrapsíquico; não é concreto. Quando recupera a noção de melancolia de Freud para tratar de reconhecimento, as relações intersubjetivas se dão entre o sujeito e um outro abstrato, fantasiado. É a relação entre o sujeito e o objeto que foi perdido, ao qual não temos mais acesso, mas com o qual nós nos mantemos vinculados pelo sentimento de perda, pela melancolia.

O “outro", portanto, termina sendo uma abstração. Nós nos relacionamos pela imagem que fazemos dele em nossa mente, e não com um outro real e concreto. A questão que isso levanta é: isso não é incompatível com o modo de contextualização do sujeito em Butler? Não é, pois a contextualização se dá por um processo de relação entre o sujeito e regra disciplinar. Sua perseverança em recusar o humanismo afasta a intersubjetividade, exclui o papel do "outro" na construção do sujeito. Em Butler, ele permanece como risco de destruição, é ameaçador porque quer roubar o reconhecimento do "outro", ou seja, o seu lugar no mundo ${ }^{193}$.

\footnotetext{
${ }^{191}$ Idem.

192 Benjamim, J. " The Shadow of the Other Subject”, p. 85

${ }^{193}$ Benjamim, J. The bonds of love, pp. 19-20
} 
Em Benjamim, no entanto, o "outro" aparece tanto na dimensão intrapsíquica como na dimensão intersubjetiva, ou seja, tanto como uma abstração como um outro concreto. Cito:

"Eu sugiro que as teorias intrapsíquica e intersubjetiva não devem ser vistas como opostas (como geralmente são), mas como formas complementares de entender a psique. Reconhecer o self intersubjetivo não é negar a importância do intrapsíquico: o mundo interno da fantasia, desejo, ansiedade e defesa; dos símbolos corporais e imagens são as conexões que desafiam as regras ordinárias da lógica e da linguagem. No mundo interno, o sujeito incorpora e expele, identifica-se e repudia o outro, não como um ser real, mas como um objeto mental. (...).

$\mathrm{Na}$ minha visão, o conceito que unifica teorias intersubjetivas do desenvolvimento do self é a necessidade de reconhecimento. Uma pessoa sente que "eu sou um agente que age”, eu sou o autor dos meus atos”, à medida que está com outras pessoas que reconhecem seus atos, seus sentimentos, suas intenções, sua existência, sua independência, Reconhecimento é a resposta essencial, a companhia constante dessa afirmação. O sujeito declara 'eu sou”, "eu faço” e espera pela resposta "você é, você faz”. O reconhecimento é, portanto, reflexivo; ele inclui não apenas a confirmação do outro, mas também como nos encontramos nessa resposta". 194

O reconhecimento no self é paradoxal, já que no self convivem o desejo de independência, que nos afasta do outro, e o desejo de reconhecimento, que nos relaciona ao outro. Em Hegel, diz Benjamim, o desejo de independência é predominante, pois a reciprocidade abstrata, fantasiada no nível psíquico, não exprime o modo como o sujeito experimenta a relação com o outro real. O self é um absoluto para

\footnotetext{
${ }^{194}$ Benjamim, J. The bonds of love, p. 20-21. Citação no original: “I suggest that intrapsychic and intersubjective theory shuld not be seen in opposition to each other (as they usually are) but as complementary ways of understanding the psyche. To recognize the intersubjetive self is not to deny the importance of the intrapsychic: the inner world of fantasy, wish, anxiety, and defense; of bodily symbols and images whose connections defy the ordinary rules of logic and languade. In the inner world, the subject incorporates and expels, identifies with and repudiates the other, not as a real being, but as a mental object. (...) In my view, the concept that unifies intersubjective theories of the self development is the need for recognition. A person comes to feel that 'I am the doer who does, I am the author of my acts' by being with another person who recognizes her acts, her feelings, her intentions, her existence, her independence. Recognition is the essential response, the constant companion of assertion. The subject declares, "I am, I do", and then waits for the response, "You are, you have done”. Recognition is, thus, reflexive; it includes not only the other's confirming response, but also how we find ourselves in that response".
} 
sim mesmo. O outro funciona para ele apenas com um instrumento para a sua afirmação $^{195}$.

Benjamim, porém, afirma que não há hierarquia entre o desejo de autoafirmação e o desejo de reconhecimento. A afirmação do self somente se completa quando o outro não é simplesmente um espelho ou um opositor, mas quando reconhecemos sua singularidade. O processo de individualização, portanto, supõe a reciprocidade entre o sujeito e o outro. Ambos precisam desenvolver a dimensão intrapsíquica do self, pela melancolia, mas precisam também desenvolver sua dimensão social, pela relação intersubjetiva com um outro, que reconhecemos como um ser que existe em relação a nós, mas que também existe em relação a si mesmo.

Enfim, não somos apenas um ego que instrumentaliza o outro para confirmar nossa existência. $\mathrm{O}$ outro não nos serve apenas para espelhar e confirmar nosso eu interno. Nosso "eu" não é criado pelo sacrifício do "outro", como diz Butler. O "outro" tem também sua própria singularidade, de cujo reconhecimento depende nossa diferenciação, nossa individualização; depende, enfim, a nossa identidade ${ }^{196}$.

A tese de Benjamim sobre reconhecimento deixa claro que falta em Butler um dos pólos para explicar a formação da identidade feminina. Falta o "outro". E faz isso sem perder de vista a relação do self consigo mesmo, ou seja, sem reduzi-lo a uma projeção do "outro". Embora Butler tenha ensaiado a adoção de uma concepção de reconhecimento que vai além da subordinação, seu recente debate com Benjamim deixa claro que Butler persiste na recusa em contemplar a possibilidade do reconhecimento mútuo.

Em Butler, a vulnerabilidade humana é o ponto de partida para a formação da comunidade política e da resistência coletiva. Essa vulnerabilidade explica a necessidade de reconhecimento e o impulso de cumprir a norma disciplinar. Mas não consegue explicar porque resistimos à norma. Para dar esse passo seria preciso que ela

195 A tensão entre reconhecimento e destruição caminha para a ruptura porque o processo de contradição traz consigo o germe do processo de dissolução. Do contrário, não haveria movimento e mudanças históricas ${ }^{195}$. Benjamim extrai a explicação dessa ruptura da "dialética do senhor e do escravo" em Hegel. A relação entre dois "selves" se dá em função da necessidade de reconhecimento, pois a existência de cada um depende da existência do outro, ou seja, do reconhecimento do outro. Benjamim, "the bonds of love", p. 33 
entendesse a vulnerabilidade humana como interdependência e não como dependência. Assim, ela introduziria a concepção de intersubjetividade, porque o reconhecimento seria fruto não apenas da relação entre sujeito e poder, mas da relação entre sujeitos que dependem um do outro. Desse passo, depende a possibilidade de Butler transpor o fosso entre "sua agenda política progressista e seus comprometimentos teóricos "197, pois assim ela poderia explicar os vínculos que unem os movimentos sociais, as identidades, não necessariamente como algo opressor e excludente, mas também como redes de solidariedade que dão força e visibilidade a reivindicações de grupos oprimidos, como é o caso do movimento feminista.

O reconhecimento mútuo não leva, como diz Butler, a uma identidade homogênea e estável, ao menos não na concepção de Benjamim. Isto porque o "outro" não é o espelho do eu. Para reconhecer o outro não é preciso que seja igual a mim. Assim como Benhabib, Benjamim busca em Arendt a relação entre igualdade e diferença. Ela afirma que o reconhecimento do outro não equivale à opressão de sua singularidade, pois relacionar-se com o outro não é o mesmo que misturar-se com ele. Como diz Arendt, nós somos todos iguais e diferentes. Somos iguais porque somos todos humanos, mas somos singulares porque nossa história de vida é única ${ }^{198}$.

O reconhecimento precisa dar conta de ambos os aspectos da condição humana, a igualdade e a diferença. Nossa singularidade não é colocada em risco porque estamos em relações com nossos interlocutores. Ao contrário, já que, como diz Arendt, é nessa relação que nossa singularidade aparece. Nossa singularidade, portanto, é indissociável da pluralidade ${ }^{199}$.

Admitindo-se que a pluralidade é condição de possibilidade da ação política, como em Arendt, a tese de Butler mostra-se problemática para explicar tanto a ação coletiva quanto a resistência individual ${ }^{200}$. Embora a acusação de que o sujeito em Butler seja determinado pelo meio seja injusta ${ }^{201}$, a sua resistência em vislumbrar a possibilidade de reconhecimento mútuo compromete a força transformadora de sua teoria. Como diz Amy Allen:

\footnotetext{
${ }^{196}$ Benjamim, “ The bonds of Love”, pp. 25 e ss.

197 Allen, Amy. , p. 92.

198 Arendt, H. The Human Condition., p. 8 . Vertambém cap. 2 deste trabalho, p.

199 Idem

${ }^{200}$ Allen, The politics of ourselves, p. 93.
} 
"Sem uma concepção sobre como o reconhecimento de que o que há em comum entre nós ("commonality") provê a base para a comunidade política e resistência coletiva, Butler continua sugerindo que a transformação da identificação para a desidentificação, da significação para a ressignificação, da subjetificação para uma dessubjetificação crítica não é nada mais do que uma questão de sorte ${ }^{202}$.

\section{II) Intersubjetividade, Reconhecimento e Identidade}

A intersubjetividade é condição para admitir o "outro" como um ser concreto. Sem isso, conforme dito no item anterior, o outro é resumido à mera abstração, a uma figura que existe apenas em nossa mente.

A proposta de Benhabib é explorar a dimensão intrapsíquica do ser humano na constituição do self sem prejuízo da dimensão intersubjetiva, relacionado assim o desenvolvimento psíquico com o moral, numa trilha muito semelhante à de Benjamim.

Benhabib subscreve a idéia de Benjamim de que o reconhecimento unifica a dimensão externa e interna da relação com o outro. Desse modo, ela ressalta que a idealização do outro e a negação do outro funcionam da mesma forma. O outro somente terá relevância se for ao mesmo tempo introjetado na mente (melancolia) e também reconhecido politicamente. O reconhecimento do outro dependerá tanto de instituições e códigos culturais da esfera púbica; como da história psíquica individual do self ${ }^{203}$.

A concepção bidimensional de reconhecimento de Benjamim afasta o risco de reduzi-lo à assimilação do outro. Sem a face da destruição, da negação do outro, a diferença é reprimida. Politicamente, isso leva ao despotismo, já que neste caso os indivíduos são condensados em um todo. São todos iguais à custa da singularidade de cada um, porque essa igualdade é atribuída sem uma esfera democrática que permita o diálogo entre iguais para a construção da diferença. Eliminado a diferença, o despotismo nega também a possibilidade da política ${ }^{204}$.

No entanto, rejeitar a assimilação total não requer rejeitar qualquer identificação com o outro. Politicamente essa idéia se traduz em práticas de extermínio dos grupos

\footnotetext{
${ }^{201}$ Ver cap. 2 deste trabalho, PP.

202 Allen, Amy. The politics of ourselves, p.93.

${ }^{203}$ Benjamim, J. The bonds of love, p. 21.

${ }^{204}$ Benhabib. "Sexual and Collective Identities.., p. 354 e 353. Benhabib refere-se ao fim da política em sentido arendtiano. Conforme comentado no capítulo anterior, a política em Arendt depende tanto da igualdade quanto da diferença, já que a ação se dá por meio do diálogo, que produz a diferença entre os seres humanos, mas que é viabilizado pela igualdade.
} 
mais minoritários, vistos sempre como uma ameaça à coerência da identidade hegemônica.

Se a existência do self depende de uma concepção de inclusão, como em Benjamim e Benjabib, o outro não representará apenas uma ameaça, ele será também a possibilidade de constituição do self. ${ }^{205}$. O reconhecimento mútuo pressupõe que os sujeitos estão sempre em relações intersubjetivas nas teias de interlocução e que é delas que emerge a identidade do sujeito. Destruindo o interlocutor, a narrativa torna-se inviável e, com isso, o próprio self não consegue se constituir ${ }^{206}$.

No entanto, diz Benhabib, Benjamim não aproveita totalmente seu insight sobre reconhecimento porque distingue o self da identidade ${ }^{207}$. Ela sugere que a identidade não é capaz de abarcar a complexidade do self, porque ela precisa se expressar como algo uniforme. Cito Benjamim:

"Eu gostaria de fazer um esboço da idéia de self que deve sustentar a demanda da inclusão, mas que não precise sustentar uma identidade, que é necessariamente criada através da exclusão [como diz Butler]. (...) Identidade não é o self. Incluir sem assimilar ou reduzir exige que se vá além das alternativas binárias de identidade fechadas e permanentes e noções de multiplicidade dispersivas. Que tipo de self pode sustentar a multiplicidade, ou a oposição à identidade, que a relação com o outro diferente requer: (...) Uma noção de self inclusivo exige que pensemos sobre o que o self é capaz, suas catástrofes, conforme apareçam na situação psicanalítica. Relacionado o self à sua relação com o outro concreto, localizamos a fragilidade do self, o espaço da intersubjetividade que está sempre em aberto, uma possível reciprocidade da diferença e reconhecimento (...) ${ }^{208}$

Benhabib afirma que a distinção entre identidade e self revela que Benjamim incorporou o preconceito pós-moderno contra a identidade. Benjamim, de fato, fala explicitamente em caráter necessariamente excludente da identidade.

No entanto, diz Benhabib, em seu modelo narrativo da identidade, a identidade e o self não precisam ser separados. A identidade não é uniforme no tempo porque seu núcleo reside na capacidade de gerar significados através do tempo, e não em um

\footnotetext{
${ }^{205}$ Benhabib "Sexual Difference and Collective Identities, p. 348 e Benjamim, J. " The Shadow of the other"..p, 246 e 247.

${ }^{206}$ Benhabib, "Sexual Difference and Collective Identities, pp. 350.

${ }^{207}$ Benhabib. "Sexual Difference and Colletive Identities", p. 353.

${ }^{208}$ Benjamim, J. “The Sahdow of the other”, pp. 247 e 248.
} 
significado específico. Os significados são sempre provisórios porque estão sempre submetidos a novas narrativas formuladas a partir de novas interpretações ${ }^{209}$.

A dificuldade de Benjamim em equiparar o self com a identidade está na sua rejeição à coerência da identidade, que ela herda de Butler. Afinal, mesmo no self narrativo, os significados produzidos, embora sejam provisórios, são o produto da capacidade de reunir uma gama de narrativas em um discurso coerente sobre si mesmo e de seu entorno. Portanto, as identidades aqui, ainda que sejam provisórias, requerem uma sintese da multiplicidade de significados que emergem das redes de interlocução. Quando narramos nossa própria história, nós a descrevemos de modo linear e consistente, ainda que num momento posterior nós a recontemos de modo distinto ${ }^{210}$.

Benhabib afirma que Benjamim e Butler confundem síntese com coerência. A síntese não equipara inclusão a simbiose ${ }^{211}$. No entanto, é apenas na teoria de Benjamim que Benhabib vê a possibilidade de reconciliar identidade e reconhecimento. $\mathrm{Na}$ verdade, ela afirma que isso não é apenas possível, é necessário. Afinal, em Benjamim, o reconhecimento requer o respeito pela autonomia do outro e pelo o seu igual direito à diferença. A capacidade de produzir sínteses das narrativas é condição para incluir o outro sem assimilá-lo porque a produção de histórias individuais e coletivas das várias vozes dentro de nós pressupõe capacidade de síntese. Do contrário, o self se descentraria a ponto de se destruir ${ }^{212}$.

A identidade não requer isso. É possível fazer parte de um grupo, de uma coletividade, sem que sejamos reduzidos a uma categoria estática e opressora. Isto porque, as narrativas que emergem das redes de interlocução, ainda que sintetizem a multiplicidade dos discursos da rede, não chega a constituir um regime de verdade que cria a ficção da identidade permanente e coerente, como dizem Butler e Foucault.

A provisoriedade é inseparável da identidade porque o processo de interação discursiva é constante. Toda síntese será incessantemente revista, não apenas por mim, mas por todos os participantes da rede de interlocução. A rede de interlocução, enfim, é dinâmica, instável e contextualizada, justamente porque o material que a constitui são as narrativas que emergem de diálogos contínuos ${ }^{213}$.

\footnotetext{
${ }^{209}$ Benhabib, “ Sexual Difference and Collective Identities', p. 353.

${ }^{210}$ Idem.

${ }^{211}$ Benjamim se opõe a Butler

${ }^{212}$ Benhabib. "Sexual Differences and Collective Identities", p. 354.

${ }^{213}$ Benhabib. "Sexual Difference and Collective Identities", p. 354.
} 
Enfim, o que é realmente relevante para que a identidade não seja necessariamente uma instância de opressão e exclusão, é a concepção de provisoriedade aliada a uma noção de reconhecimento, que admita a dimensão da intersubjetividade (ao lado da psíquica), que admita que o "eu" e o "outro" cumpram a função de se construírem reciprocamente. Ou seja, que o outro não precise ser sacrificado para que o eu exista. O desafio, portanto, é pensar de que modo deve funcionar a rede de interlocução a fim de que o diálogo entre os participantes não seja apenas destrutivo, mas também construtivo de identidades não essencializadas, provisórias e que resultem de um diálogo no qual todos têm igual direito de participação.

\section{III) Reconhecimento e Igualdade sem Identidade}

Fraser sustenta que o modelo da identidade é problemático porque impõe uma demanda pela diferença excludente. Nesse ponto Fraser acompanha Butler, daí seu argumento de que é preciso incorporar a desconstrução da identidade à demanda feminista.

No entanto, Fraser, ao contrário de Butler, busca uma concepção de igualdade, de uma normatividade que oriente a emancipação dos grupos socialmente oprimidos. Ela não vê necessidade de a identidade funcionar como o elemento de coesão desses grupos. Tampouco considera que seja estrategicamente desejável, porque a identidade supõe e impõe a homogeneidade ao grupo ${ }^{214}$.

Essa homogeneidade, diz Fraser, oprime os indivíduos porque lhes obriga a se adequarem à cultura do grupo. A identidade coletiva, assim, termina sendo uma concepção reducionista do conjunto das identidades dos seus membros que, além de negar a complexidade da composição do grupo, trata as identidades como algo estático e impermeável a interações ${ }^{215}$. Além disso, ela subscreve a idéia de Butler de que essa reificação não é apenas simplificadora, é um modo de obscurecer os conflitos de interesse dentro do próprio grupo e as assimetrias de poder presentes na escolha da representação do grupo ${ }^{216}$.

\footnotetext{
${ }^{214}$ Fraser, N, op. Cit, p. 106.

${ }^{215}$ Fraser, N. "Rethinking recogntion: overcoming displacement and reification in cultural politics". New Left Reviw, n.3, p. 107-20, (may-june)

${ }^{216}$ Fraser, N. Reconhecimento sem ética $a_{i} . .$, p.107.
} 
Fraser também rejeita concepções de reconhecimento que substituem o foco na cultura reificada por especulações sobre a estrutura psíquica do indivíduo da demanda por reconhecimento. Em seu debate com Axel Honnhet, ela afirma que ele privilegia esse aspecto em detrimento do papel que as relações intersubjetivas e as instituições cumprem na inclusão social ${ }^{217}$. Essas investigações, diz Fraser, podem levar a substituir "a mudança social por formas intrusas de engenharia da consciência” $^{218}$.

Honneth sustenta que a falta de reconhecimento deprecia a identidade e não permite que as pessoas tenham uma visão positiva de si mesmas. Seu argumento é o de que o não reconhecimento deteriora a subjetividade. Essa depreciação resulta de concepções de bem que hierarquizam os indivíduos conforme o grupo social a que pertençam. A opressão à homossexualidade, por exemplo, exprime uma determinada concepção do que deve ser a sexualidade. É um padrão cultural introjetado pelo indivíduo desde as primeiras fases da formação de sua identidade ${ }^{219}$.

A preocupação de Fraser em afastar essa abordagem psíquica do reconhecimento está na responsabilização da própria vítima da discriminação. Considerar que a falta de reconhecimento gera um "dano psíquico" pode estigmatizar ainda mais os grupos oprimidos. Além disso, se o não reconhecimento implica a internalização do preconceito pelo próprio discriminado, a política de reconhecimento teria que reverter a auto-depreciação impondo de algum modo a auto-valorização. Teria que impor concepções de bem aos grupos discriminados. Para Fraser isso é autoritário $^{220}$. Com isso ela não pretende negar que a falta de reconhecimento produza efeitos psicológicos. Ela diz apenas que a solução disso independe desses efeitos e nem deve agir sobre eles ${ }^{221}$.

Para evitar tanto o reconhecimento relacionado à cultura que compromete as particularidades individuais e as assimetrias, como o reconhecimento relacionado à psique que deprecia a dimensão social do reconhecimento, Fraser sugere que o

\footnotetext{
${ }^{217}$ Fraser, N. e Honneth, A. Redistribuion or recogniton ${ }_{6}$ A political philosophical Exchange. Nova York, 2003.

218 Idem,

${ }^{219}$ Honneth, A. "Integrity and disrespect: principles of a conception of morality based on the teory of recognition. Political Tehroy, n. 20 (2), p. 188.

${ }^{220}$ Idem, p. 114.

${ }^{221}$ Idem, ver nota 5 , p. 114.
} 
reconhecimento seja tratado como uma questão de status. Tratar o reconhecimento dessa forma implica relacioná-lo ao modo como as instituições valoram a condição dos atores sociais. A falta de reconhecimento, portanto, será detectada pela desvalorização de determinados atores pelas instituições. Fraser cita como exemplo de falta de reconhecimento a proibição do casamento entre pessoas do mesmo sexo, políticas de bem estar social que estigmatizam mães-solteiras como sexualmente irresponsáveis e práticas de policiamento que pressupõem que determinados grupos raciais são mais propensos a praticar crimes ${ }^{222}$.

Todas essas discriminações exigem políticas de reconhecimento, mas, segundo Fraser, isso não precisa e não deve ser feito a partir de políticas de identidade. Garantindo aos atores estigmatizados a condição de parceiros integrais na interação social, o reconhecimento é assegurado. A política de reconhecimento deve ter por finalidade a superação da subordinação e não a valorização da identidade, do particular. A luta pelo reconhecimento, portanto, é a luta pela desinstitucionalização da desvalorização de determinados grupos, que os impede de participar como iguais de seu grupo social ${ }^{223}$.

O reconhecimento como status, diz Fraser, apresenta várias vantagens sobre o reconhecimento focado na identidade coletiva ou na harmonia psíquica. A primeira vantagem é a de evitar a essencialização do grupo, problema insistentemente apontado por Butler. A segunda é manter o foco nas mudanças sociais e não em "reengenharias da consciência". A terceira refere-se ao fato de a paridade de participação social ser um modo de integração social incompatível com reivindicações segregadoras. A quarta vantagem corresponde à rejeição da reificação da identidade coletiva sem comprometer sua relevância política. E, finalmente, a quinta vantagem refere-se ao fato de o reconhecimento como paridade de participação política ser localizado no campo da justiça e não nas questões de boa vida, permitindo assim que princípios universais de igualdade incidam sobre discriminações por falta de reconhecimento $^{224}$.

\footnotetext{
222 Idem, p. 108.

${ }^{223}$ Idem, p. 109.

${ }^{224}$ A quarta vantagem é uma crítica a Butler. Embora Fraser esteja de acordo com Butler acerca do caráter opressor e excludente da identidade, ela reconhece que ela pode cumprir um papel político. A
} 
Tratar o reconhecimento como uma questão de justiça leva à reflexão sobre a sua relação com a redistribuição. Primeiramente, Fraser deixa claro que reconhecimento e redistribuição não podem ser simplesmente tratados como sinônimos. Nem todo problema de redistribuição é reflexo da depreciação cultural. Como exemplo, ela descreve o caso do homem branco que trabalha em uma indústria e que fica desempregado depois do fechamento da fábrica. Aqui, a falta de redistribuição não pode ser reduzida ao problema da falta de reconhecimento. De outro lado, a falta de reconhecimento não pode ser reduzida à falta de redistribuição. Para esse caso o exemplo de Fraser é o do banqueiro de Wall Street afro-americano que não consegue pegar um táxi ${ }^{225}$.

Assim, para integrar reconhecimento e redistribuição em uma concepção de justiça é preciso que seu núcleo normativo seja a "paridade de participação", ou seja, a igualdade na participação política de todos os membros adultos de uma sociedade. Para isso, Fraser afirma que é preciso satisfazer condições objetivas e intersubjetivas. As condições objetivas da paridade de participação referem-se à distribuição de recursos capaz de garantir independência e voz aos participantes. Isso é incompatível com a exploração e grandes desigualdades materiais, ou ,no tempo disponível para o lazer. Alguma disparidade material sempre haverá, mas somente deverá ser tolerada se não comprometer a paridade de participação. As condições intersubjetivas, por sua vez, referem-se aos padrões institucionalizados de valoração cultural. Para que sejam compatíveis com a paridade de participação, as normas institucionalizadas que depreciam algum grupo de pessoas serão inválidas ${ }^{226}$.

Juntas, as condições objetivas e intersubjetivas da paridade de participação resolvem a tensão entre reconhecimento e redistribuição porque os interpreta como dimensões de uma justiça ampla, cujo padrão normativo é a norma universalista da paridade de participação.

Isso significa recusar totalmente o reconhecimento das particularidades? Nem sempre. Fraser defende que a ênfase no reconhecimento ou na redistribuição depende da injustiça que deve ser corrigida. No caso do apartheid na África do Sul, por exemplo, a 
ênfase teve de ser no reconhecimento. No entanto, o remédio adequado para garantir o reconhecimento não esteve focado na valorização da identidade negra, mas sim na cidadania universal não-racializada ${ }^{227}$.

A afirmação de que todas as particularidades ameaçam a igualdade ou de que toda igualdade coloca em risco a identidade é fruto de uma análise descontextualizada da desigualdade. Conforme o caso, as desigualdades terão de ser corrigidas ora pelo reconhecimento da diferença, ora pela preservação da igualdade. Por isso, conclui Fraser, deve-se admitir que o reconhecimento das particularidades pode, sim, ser legitimado. Mas isso deve ser feito não em nome do culto da autenticidade, mas sim da igualdade de participação política.

\section{IV) Identidade, Subordinação e Emancipação}

A capacidade reflexiva do sujeito não é suficiente para explicar porque buscam sua emancipação de regras opressoras, pois, como diz Butler, temos uma vontade de subordinação que nos impele a cumprir a norma disciplinar. A origem dessa vontade está na dependência absoluta do bebê em relação à pessoa responsável por seus cuidados. Essa dependência cria uma sensação de desamparo permanente. Mesmo quando adultos, os indivíduos continuam temendo o abandono e a rejeição porque não confiam em sua capacidade de garantir sua própria existência. Agora não mais no sentido de se manterem vivos biologicamente, mas sim de serem reconhecidos socialmente.

No entanto, em Butler, ser reconhecido equivale a ser subordinado, pois a constituição do sujeito se dá em meio a relações assimétricas entre os sujeitos e a regra disciplinar que dita seu comportamento. Ela esclarece essa relação aproveitando o exemplo do comando policial de Althusser que indica que tanto o subordinado quanto o representante da autoridade da lei devem sua existência social a comportamentos ditados pela norma. Se o policial não agir como autoridade, reconhecendo no outro a condição de subordinado, e se este não atender a seu chamado, os papéis de ambos são destruídos. A possibilidade da crítica está justamente no fato de a confirmação da regra estar nas mãos dos sujeitos.

\footnotetext{
${ }^{226}$ Idem, p. 119

${ }^{227}$ Idem, p. 122.
} 
No entanto, Butler torna o ônus do descumprimento da regra excessivamente pesado. E isso, não apenas pelo medo da punição, mas pela perda do reconhecimento. Sem atender ao chamado policial, o subordinado perde esta sua condição, mas nem por isso torna-se uma autoridade. Ele perde seu papel, mas em troca não ganha nenhum outro. Por isso Allen diz que a crítica social em Butler requer uma vontade de autodestruição, requer o "suicídio social". Isso, porém, é incompatível com sua tese sobre o impulso de subordinação. Se o reconhecimento social é algo vital durante toda a vida humana, em nome de que o arriscaríamos?

O exemplo de Brandon, personagem do filme 'Boys don't cry”, deixa claro que o preço a ser pago pela perturbação da coerência entre anatomia, desejo e comportamento é altíssimo. Perturbar esse sistema é uma ameaça existencial a todas as pessoas que se atrelam febrilmente à sua identidade. Por isso, ameaças às regras da feminilidade e da masculinidade provocam reações brutais como o estupro coletivo de Brandon $^{228}$.

Mas é possível que uma identidade não represente sempre uma ameaça à diferença $a_{i}$ Os homens que cumprem à risca a regra da masculinidade poderiam conviver com a transexualidade de Brandon sem se sentirem ameaçados? Não. Em Butler não há espaço para o convívio pacífico e tolerante entre diferentes. A identidade vive de sua coerência e estabilidade. Trazer à tona outras formas de comportamento coloca em questão a autoridade da norma que nos atribui nossos rótulos, nossos papéis sociais, aos quais permanecemos atados a qualquer custo, nem que para isso seja preciso eliminar o outro em sentido literal. É justamente a impossibilidade de conciliar identidade com diferença que leva Butler a julgar a identidade como necessariamente excludente e a relacionar a emancipação com a desconstrução da identidade.

Benjamim e Benhabib estão corretas em diagnosticar as limitações de Butler no tema do reconhecimento e da crítica social. Ambas apontam a rejeição à intersubjetividade, ou seja, ao papel construtivo que o "outro" cumpre na formação do "eu”, como a causa da relação entre reconhecimento e destruição. Por isso em Butler a identidade é uma ameaça à diferença e vice-versa.

${ }^{228}$ Ver cap. 2 deste trabalho. 
Benjamim, porém, usa esse argumento para atacar a forma de Butler conceber o self. No entanto, ela afirma que a crítica de Butler é válida para a constituição da identidade, em particular da identidade coletiva. Assim como Butler, ela afirma que a organização coletiva em torno de uma identidade não será capaz de expressar a complexidade humana. A identidade é uma forma reducionista de classificar os seres humanos e, por isso, será sempre excludente.

Benhabib, por sua vez, chama atenção para os riscos existenciais e políticos de descartar a identidade. Ela afirma que o problema que decorre da concepção de reconhecimento de Butler está diretamente ligado à possibilidade de resistência. Ainda que seu argumento sobre a vontade de subordinação seja razoável, esta vontade não pode ser considerada a vontade humana por excelência. Ao reunir a dimensão psíquica e intersubjetiva no conceito de reconhecimento, Benhabib procura tratar da vontade de identificação não apenas como um impulso de subordinação. Embora esteja de acordo com Butler em relação à idéia de que os seres humanos buscam o reconhecimento a qualquer custo, ela não acredita que essa busca leve sempre à subordinação.

Benhabib se opõe a isso afirmando que o reconhecimento atende também à demanda de ser valorizado, incluído e tratado como um igual. A identidade, portanto, não tem apenas a face da subordinação, pois ela cumpre também o papel de viabilizar a emancipação. Em Benjamin, porém, ela encontra esse duplo aspecto do reconhecimento, mas que, diz ela, surpreendentemente desemboca numa rejeição da identidade. Em Benjamim, porém, essa rejeição não se deve à recusa da mutualidade, como em Butler. Ela, ao contrário, é explicita na crítica a Butler por não admitir o reconhecimento intersubjetivo.

A razão pela qual Benjamim junta-se a Butler para se opor à identidade é a generalidade. Para ela, a universalização da categoria mulher é, inevitavelmente, opressora porque todo rótulo será reducionista. Assim, apesar de as diferenças entre Benjamin e Butler serem muito marcadas, ambas compartilham a recusa ao caráter emancipatório da identidade, o que apresenta dificuldades relevantes para os movimentos sociais, inclusive para o feminismo. 
Butler, às vezes, fala no uso estratégico da categoria mulher, mas em outros momentos ela recua. Esse recuo não se dá à toa. É um recuo que se deve à retomada da epistemologia na qual a tese de Butler está inserida. Seus passos rumo à intersubjetividade e à ética implicaram um progressivo abandono de sua concepção de sujeito, que sustenta sua tese. Por isso, essa virada "humanista" de Butler foi logo revertida $^{229}$.

No caso de Benjamim, porém, a situação é distinta. Ela dispõe de todas as ferramentas teóricas para não descartar a identidade. Para Benhabib, basta que Bejamim estenda sua tese sobre a constituição do self à constituição da identidade, unificando ambos os conceitos.

A recuperação do status emancipatório da identidade não é exclusivamente teórico. Para que a resistência não seja sinônimo de autodestruição e nem requeira um sujeito racional, abstrato, dono de si mesmo, capaz de se auto-reconhecer, é preciso admitir a importância das identidades coletivas para mobilizar e exprimir as reivindicações dos grupos mais vulneráveis. Para criticarmos uma regra disciplinar, precisamos de outra rede de interlocução que nos acolha, que nos dê reconhecimento. Butler tem razão em mostrar que a crítica exige muito mais do que o desvelamento da situação de opressão. Ela exige que nós afrontemos nossa identidade. Mas, como ela mesma diz, ficar sem identidade é o mesmo que uma morte social.

O único modo de a emancipação da identidade opressora não ser autodestrutiva é admitir que podemos buscar a fonte de nosso reconhecimento em outros grupos organizados em torno de uma identidade.

Os movimentos gay, negro e feminista, e tantos outros, tiveram e têm exatamente este papel. Constróem novas regras disciplinares nas quais a condição de homossexuais, negros e mulheres é aceita e valorizada. Uma vez criados esses núcleos, o indivíduo poderá arcar com o ônus da exclusão da regra disciplinar hegemônica, porque terá onde buscar abrigo.

A crítica social não é uma tarefa individual. Ninguém pode suportar esse ônus sozinho. Se na cidadezinha do filme "boys don't cry" houvesse um movimento de transexuais, muito provavelmente a vida de Brandon teria sido mais fácil.

${ }^{229}$ Butler.. e Allen 
Além disso, o grupo cumpre a função de dar maior visibilidade, força e reivindicação a demandas que individualmente seriam massacradas antes mesmo de ganharem força. Portanto, a fusão entre identidade e exclusão gera dois problemas, um existencial e outro político.

Mas a criação desses novos grupos cria, necessariamente, novas exclusões? A resposta de Butler é sim; e a de Benhabib e Fraser é não necessariamente. Ainda que Butler sugira muitas vezes que não descarte totalmente a identidade, mas apenas reconhece que ela deve estar sempre sujeita à ressignificação, isso não afeta sua rejeição à identidade. Por mais que seja ressignicada, ela será sempre construída pela destruição da diferença.

A sua concepção de espaço social, herdada de Foucault, afasta a possibilidade do reconhecimento recíproco. Todo grupo será formado pela definição de um "nós" que descarta os "outros. Isso vale para os grupos poderosos como para os mais vulneráveis. Em outras palavras: os grupos minoritários funcionam da mesma forma que os majoritários. Criam e reproduzem normas que definem quem deve ser incluído e quem deve estar excluído. Em ambos os casos, o sujeito está aprisionado, tanto os de dentro, quanto os de fora.

Fraser também fala do caráter homogeneizante da identidade. Mas a identidade que tem em mente são concepções reificadas de teorias comunitaristas. Já quando fala da concepção psicologizante, ela tem em mente a formulação de Honneth, para quem a falta de reconhecimento está na origem de todas as desigualdades. Benhabib, porém, parece oferecer um modelo de reconhecimento que integra ambas as dimensões, a social e a psíquica, sem prejuízo de nenhuma delas. Seu modelo parece ser mais vantajoso do que o de Fraser porque ao explorar os efeitos psíquicos da discriminação social, ela trata também da motivação da crítica, tanto da crítica que combate desigualdades de reconhecimento quanto de distribuição.

O caso das alunas de Cornell revela o potencial da teoria de Benhabib. Sem explorar a vontade de subordinação, não há como explicar porque elas se submetem à regra da feminilidade. Essa regra está em parte refletida em instituições, mas também está difusamente espalhada em práticas sociais que oprimem e limitam a auto-realização de cada membro da sociedade. Outro exemplo que pode ser dado é a distribuição sexual das tarefas domésticas. Essas normas tampouco são expressas, mas condicionam o comportamento não apenas dos homens, mas também das mulheres. Para chegarem a se 
engajar na luta pela paridade de participação, a distribuição de papéis sociais no âmbito doméstico precisa ser revista. É preciso que as mulheres questionem a identidade que lhes foi atribuída pela cultura.

Em ambos os exemplos, as desigualdades refletem concepções de boa vida que são absorvidas pela psique de cada indivíduo desde suas primeiras relações intersubjetivas e condicionam a possibilidade de os sujeitos lutarem pela igualdade de participação. Assim, ao afastar a dimensão psíquica do reconhecimento, Fraser afasta a análise das auto-limitações que os atores sociais enfrentam para reivindicarem tanto a igualdade de reconhecimento quanto a de redistribuição.

Ao contrário do que diz Fraser, a psicologização do reconhecimento não implica a vitimização e a responsabilização do próprio discriminado por sua discriminação. Ela apenas traz à tona os obstáculos que cada indivíduo enfrenta para questionar sua própria discriminação, mesmo depois de tê-la reconhecido como tal. Minimizar esse obstáculo gera um risco muito maior de responsabilizar o discriminado por sua discriminação. Se as mulheres insistem em serem anoréxicas, insistem em assumir a maior parte das tarefas domésticas, então porque corrigir isso?

Reconhecer as implicações da vontade de subordinação não é o mesmo que tratar os grupos oprimidos como doentes psíquicos. Isso implica apenas levar a sério os riscos existenciais que a emancipação envolve; riscos estes que são diluídos quando um grupo social oferece abrigo e reconhecimento àqueles que ousam criticar os valores sociais hegemônicos.

Isso não necessariamente se traduz em um culto à identidade essencialista e excludente. No caso do feminismo, Benhabib afirma que a categoria "mulher" não encobre, necessariamente, as diferenças e conflitos entre elas, desde que a identidade seja mantida permanentemente em discussão entre os participantes do grupo. Essa discussão distingue-se da ressignificação de Butler porque pressupõe um modo de organizar esses diálogos que garanta a todos igual capacidade de participação. Não se trata, portanto, de uma reconfiguração das relações de poder. Trata-se de uma permanente revisão da categoria mulher a fim de torná-la, progressivamente, mais inclusiva.

A diferença fundamental entre Benhabib e Fraser é a de que Fraser considera que a identidade é excludente porque promove um culto a concepções particulares de bem, e Benhabib acredita que, apesar de a identidade refletir particularidades, isso não 
significa que seja, necessariamente, excludente. Elas, no entanto, estão de acordo quanto à possibilidade de criar espaços intersubjetivos regidos por regras igualitárias que condicionam a validade das normas que emergem das interações sociais. Ao menos como um ideal normativo, elas admitem essa possibilidade. É a essa possibilidade que ambas creditam o caráter emancipatório dos movimentos sociais, inclusive do feminismo.

Mas os espaços regidos por regras igualitárias não retomam a ilusão do espaço social desprovido de assimetria? Essa concepção de igualdade não é apenas mais uma regra disciplinar que esconde os conflitos por trás da norma?

Aqui tanto Benhabib como Fraser encontram em Habermas o potencial para conceber princípios universais de justiça compatíveis com o respeito à diferença; mas ressaltam que o feminismo exige algumas modificações em sua teoria. As modificações que cada uma delas fará, porém, é bastante distinta, conforme se verá no capítulo seguinte. 


\section{CAPÍTULO IV: Identidade e diferença}

O principal argumento do capítulo anterior é o de que a identidade cumpre um papel importante para a crítica social. No entanto, isso não implica uma defesa da reificação da personalidade individual ou da cultura. Desde "Gender Trouble", Butler tem contribuído para desmistificar esse tipo de reivindicação, no que tem sido acompanhada por boa parte das feministas contemporâneas, tanto modernas quanto pósmodernas.

No entanto, se continuamos considerando que a identidade tem um potencial emancipatório, é preciso pensar em alguma concepção de igualdade que não seja essencializada, mas que seja capaz de funcionar como uma referência em torno da qual os grupos sociais se organizam. Só desse modo a crítica social não vira sinônimo de autodestruição.

A concepção de reconhecimento de Benhabib indica que esse caminho é possível, já que a identidade é produto de relações intersubjetivas que se desenvolvem em uma rede de interlocução. Tendo essa concepção de reconhecimento como ponto de partida, podemos admitir que a igualdade e a diferença são interdependentes e que, por isso, podem conviver pacificamente.

No entanto, resta ainda saber de que forma essas relações intersubjetivas devem funcionar para que essa relação possa se desenvolver de modo que o "eu" e o "outro" coexistam. Benhabib encontra tanto em J. Benjamim como em Hannah Arendt as ferramentas para essa concepção de igualdade. Mas ambas as autoras não a desenvolvem. Benjamim, simplesmente, rejeita essa possibilidade quando afirma que a identidade é sempre excludente. Mas isso, conforme visto no capítulo anterior, contradiz sua concepção de reconhecimento.

Hannah Arendt, por sua vez, parece rejeitar explicitamente essa possibilidade quando se mostra cética em relação ao papel que os Direitos Humanos cumprem no controle e organização da política no século XX. No entanto, diz Benhabib, a normatividade que não foi teorizada por Arendt esteve sempre implícita em sua concepção de intersubjetividade ${ }^{230}$. Segundo Benhabib, o pensamento de Arendt está

\footnotetext{
${ }^{230}$ Benhabib, S “Rethinking Arendt's Political Tehory” in The Reluctant Modernism of Arendt, p. 194.
} 
fundado em um "universalismo filosófico". Em seu livro, "A condição Humana", os seres humanos são descritos como membros naturais de uma mesma espécie, cuja existência se dá pelo desenvolvimento de três atividades: o labor, a fabricação e a açãO.. O nível de abstração da reflexão de Arendt exprime uma concepção universal de ser humano, uma vez que essas atividades definem a especificidade do humano a despeito das particularidades culturais, sociais e históricas ${ }^{231}$.

Essa universalidade, por sua vez, sugere uma ética implícita no pensamento de Arendt. É uma ética que deriva do fato de sermos fundamentalmente iguais e de pertencermos ao mesmo grupo, o da humanidade. Essa concepção de igualdade, por sua vez, é indissociável da de diferença. É da combinação de ambas que emerge nossa pluralidade. A pluralidade é a "condição da igualdade na diferença" ${ }^{232}$.

A pluralidade exprime o caráter intersubjetivo da própria formação do self, do nosso nascimento para o mundo humano, como diz Arendt. O nascimento físico é condição para nossa integração no mundo, mas nossa sobrevivência depende da solidariedade e do cuidado de quem era responsável por nós em nossa primeira infância. O nascimento para o mundo, por sua vez, requer o respeito mútuo, que é uma espécie de "amizade" sem intimidade. Não é baseada no afeto particular, é um sentimento de respeito que se desenvolve apesar da impessoalidade das relações humanas no mundo ${ }^{233}$.

Benhabib argumenta que Arendt não trata do desenvolvimento do respeito mútuo, não explica como se dá a passagem da fase em que o ser humano é puramente dependente e egocêntrico para tornar-se um sujeito que respeita o "outro". Para isso, ela teria que ter desenvolvido uma concepção de igualdade que justificasse sua concepção de intersubjetividade e respeito mútuo, o que ela não fez ${ }^{234}$.

O fato de a filosofia moral em Arendt estar implícita levanta o risco de um fundacionismo essencialista que ela própria quis evitar. Outra possibilidade é considerar sua resistência à filosofia moral um sinal de que Arendt foi uma "pós-moderna" à frente de seu tempo. Benhabib discorda dessas duas interpretações. O essencialismo em

\footnotetext{
${ }^{231}$ Idem, p. 195.

${ }^{232}$ Benhabib, p. 196.

${ }^{233}$ Idem.

${ }^{234}$ Idem.
} 
Arendt é aparente. Sua ênfase na construção dialógica do self é incompatível com uma fundamentação abstrata do sujeito. Tampouco o rótulo de pós-moderna é adequado. Afinal, em Arendt, a ação é a criação do novo, resulta da capacidade criativa do ser humano de gerar o imprevisível, o inesperado, de gerar rupturas radicais entre o passado e o futuro. Não por acaso Arendt escolhe o termo "milagre" para se referir às inovações produzidas pela ação humana. Embora a ação esteja condicionada pelo contexto das redes de interlocução, o "milagre" exprime uma autonomia muito mais forte do que o pós-modernismo admite. O "milagre", enfim, sugere que a ação é mais livre do que o cumprimento, subordinador ou subversivo, da regra disciplinar.

No entanto, para justificar seu milagre não metafísico Arendt precisaria ter refletido sobre o universalismo moral que está implícito em sua concepção de ação. Cito:

“É apenas quando situamos as suas reflexões mais filosóficas sobre a ação, identidade e pluralidade no contexto desenvolvimento de seu pensamento político como um todo é que notamos a persistência da tensão central em seu trabalho: entre seu universalismo moral e político quando pensa sobre as questões deste século (sec. XX) desde o sionismo, passando pelo imperialismo até o destino das pessoas sem Estado e o julgamento de Eichmann, e sua persistente aliança ao ethos filosófico do pensamento grego (...). É essa tensão que faz de Arendt uma modernista relutante. „235

Para Benhabib, é fundamental superar a relutância modernista de Arendt porque o respeito mútuo supõe uma concepção de igualdade que condicione o modo de interação humana em redes de interlocução capazes de conciliar a identidade com a diferença. Dizer que o reconhecimento é intersubjetivo ainda não é suficiente para concluir que ele não é opressor. É preciso ainda justificar o respeito mútuo ${ }^{236}$.

A emancipação de papéis sociais opressores requer a formulação de princípios de justiça que condicionem a validade moral das narrativas que resultam desses diálogos. Para criticar as identidades de gênero, por exemplo, é preciso dizer que elas

\footnotetext{
${ }^{235}$ Citação no original. "It is only when we place her more philosophical reflections on action, identity and plurality in the contexto $f$ the development of her political thought as a whole that we note the persistence of the central tension in her work: between her moral and political universalism in thinking through the issues of this century form Zionism through imperialism to the fate of staeless peoples and the Eichmann Trial, and her continuing allegiance to the philosophical ethos of Greek (...). It is this tension that makes Hannah Arendt a reluctant modernist. Idem. P. 198
} 
são injustas. Mas somente podemos dizer algo sobre injustiça, se dispusermos de uma concepção de igualdade.

No entanto, se não quisermos fundamentar essa igualdade em algum princípio metafísico, na justiça divina ou na natureza humana, é preciso pensar em um modo de justificá-lo racionalmente. Só assim podemos distinguir as relações intersubjetivas justas das injustas, só assim podemos distinguir igualdade de desigualdade e diferenciar críticas sociais emancipatórias de meras reconfigurações das relações de poder.

Para isso, é preciso que a luta contra a desigualdade não deságüe numa repressão à diferença. No feminismo, essa exigência se traduz na construção de uma concepção de igualdade de gênero que seja capaz de abarcar as diferenças entre as mulheres. Não apenas diferenças culturais, mas de classe, étnicas, históricas, etc.

Benhabib e Fraser buscam na teoria do discurso de Habermas a inspiração para construir uma concepção de igualdade pluralista, capaz de condicionar a formação das identidades individuais e coletivas sem o preço da exclusão e da abstração cultural e histórica. Habermas entende que a identidade é constituída intersubjetivamente e oferece um ideal normativo para o funcionamento da rede de interlocução na qual se desenvolvem. Assim, ele fornece não apenas o modelo para a formação da subjetividade. Ele oferece também pressuposições pragmáticas sobre a validade do discurso, que funcionam como meio para avaliar os produtos que emergem os diálogos, entre os quais está a identidade pessoal e coletiva ${ }^{237}$.

Para formular esse ideal normativo, Habermas revê a concepção de racionalidade da modernidade. Ao contrário de Max Weber, dos membros mais antigos da Escola de Frankfurt e de Foucault, Habermas vê um potencial emancipatório na razão. Ele quer recuperar o binômio razão-liberdade iluminista. Ele afirma que tratar razão e poder como termos sinônimos supõe uma concepção muito estrita de racionalidade, que a reduz à sua dimensão estratégica ${ }^{238}$.

Entender a racionalidade apenas como uma racionalidade de meio e fim compromete pretensões normativas, porque assume que o sucesso estratégico é o único

\footnotetext{
${ }^{236}$ Benhabib, S. The reluctant modernism of Hannah Arendt, p.. 185

${ }^{237}$ Meehan, J. “ introduction”, p. 2

${ }^{238}$ Meehan, J. , p2.
} 
critério apropriado para fazer julgamentos. Habermas afirma que essa visão de racionalidade desconsidera o caráter normativo dos comportamentos e das instituições modernas, bem como os ganhos que a modernidade trouxe para o campo teórico, prático e estético. Foram esses ganhos que tornaram possível a reflexividade das normas políticas e sociais, além de terem permitido a descentralização do ponto de vista moral $^{239}$.

A constituição do self em Habermas dá-se por meio da linguagem. Também aqui não há indivíduos antes da ação social, pois a identidade pessoal é social. O self é constituído juntamente com o estabelecimento de relações comunicativas. As identidades emergem de redes de relações sociais nas quais assumimos papéis específicos.

Além de nossos próprios papéis, assumimos também a perspectiva "outro generalizado". O outro generalizado é a posição do sujeito que se distancia de seu papel particular e reconhece que todos os papéis estão estruturados por normas sociais, que são compartilhadas por todos os participantes da rede de interlocução. Portanto, o outro generalizado permite a superação do ponto de vista subjetivo e particular, pois tem uma visão panorâmica das expectativas recíprocas e das interações que constituem os papéis sociais em cada sociedade. Assim, quando a tradição perde sua força, os indivíduos podem reflexivamente questionar a legitimidade das normas e irem além da justificação moral metafísica, bem como a fundamentada na tradição, ou seja, em convenções. É assim que os sujeitos atingem o estágio pós-convencional de justificação das normas $^{240}$.

A formação pós-convencional da identidade moral implica a separação entre questões de bem e questões de justiça. Quanto mais avançado for o estágio de moralidade pós-convencional em uma sociedade, mais separadas essas questões estarão $^{241}$.

As questões de bem correspondem ao conteúdo dos problemas morais e as questões de justiça referem-se à forma dos julgamentos morais. O conteúdo não pode ser universalizado, pois isso implicaria comprometer a diferença em nome de uma

\footnotetext{
${ }^{239}$ Idem.

${ }^{240}$ Idem.
} 
igualdade homogeneizante. Implicaria reprimir modos de vida de grupos menos poderosos em nome da igualdade. Essa seria, exatamente, a situação a que Foucault e Butler se referem e que os fizeram associar toda universalidade a uma forma de justificar a opressão e a exclusão.

No entanto, diz Habermas, o universal não implica esse risco se for aplicável apenas à forma, à estrutura lógica do pensamento moral ${ }^{242}$. Seguindo Kant, Habermas identifica nessa estrutura lógica três características filosóficas: o cognitivismo, $o$ universalismo e o formalismo. O pensamento moral é formal porque o julgamento irá incidir sobre a sua estrutura lógica e não em seu conteúdo. É cognitivista porque sustenta que os conflitos morais podem ser resolvidos através da argumentação. E, finalmente é universalista porque o raciocínio moral funciona da mesma forma em qualquer cultura, desde que estejam no mesmo estágio de moralidade pós-convencional.

No entanto, afastando-se de Kant, Habermas afirma que a reflexão monológica deve ser rejeitada, porque é incompatível com a concepção de construção intersubjetiva da identidade. Assim, para aproveitar o universalismo formal kantiano sem retornar ao individualismo kantiano é preciso admitir que o julgamento moral é uma tarefa coletiva. A universalidade das pretensões normativas deve ser avaliada em debates públicos nos quais a legitimidade dos interesses, reivindicações e definições de identidades serão discutidas. $\mathrm{O}$ processo de julgamento moral, portanto, não é uma tarefa do sujeito abstrato, racional moderno. É um trabalho que deve ser executado por todos os participantes de um grupo social específico.

A tradição e a religião não têm mais o poder de legitimar normas morais nas sociedades pós-convencionais. Essa é uma tarefa da razão. Por isso o foco da análise de Habermas está justamente nos procedimentos através dos quais a justificação racional das normas morais foi construída ${ }^{243}$.

O caminho para identificar e avaliar os procedimentos de justificação das normas vigentes é a reconstrução do processo de formação do conhecimento intuitivo do sujeito. Habermas analisa a estrutura normativa da comunicação e as habilidades que a comunicação exige do sujeito. É desse modo que ele reconstrói o procedimento de 
produção das normas que regulam a interação social e fundamenta sua ética universalista $^{244}$.

Trazer à tona as pretensões de validade requer habilidades próprias do sujeito moderno, como a capacidade de assimilar normas que regulam comportamentos e a produção das identidades, bem como a capacidade de distanciar-se delas e criticá-las. Essas habilidades podem ser medidas porque são referentes aos estágios cognitivos de cada sociedade. Esses estágios, por sua vez, podem ser hierarquizados sem levar em conta os valores culturais particulares.

O foco de sua teoria, enfim, está nos elementos formais do discurso normativo e reside em uma firme distinção entre normas que podem ser racionalmente julgadas e justificadas e os valores. Os valores são muito integrais à nossa identidade para permitir o distanciamento necessário para a justificação moral. Por isso, a distinção entre questões de justiça e os valores de um determinado grupo é fundamental para uma moralidade universal que seja imparcial em relação a concepções de boa vida particulares $^{245}$.

Enfim, essa distinção é necessária, segundo ele, porque uma moralidade pósconvencional deve fundamentar a legitimidade da norma em princípios justificáveis e universais e não em normas que determinem quais são os modos de vida morais e os amorais. As versões específicas de boa vida não devem ter status normativos.

Habermas sustenta que o critério ideal que estrutura os discursos é universalmente válido. No entanto, os discursos reais são sempre particulares, historicamente localizados. Assim, se os discursos são sempre particulares a um determinado tempo e a uma localidade, então as normas irão mudar continuamente ao longo do tempo. As normas justificadas em uma rodada inicial de comunicação estarão sempre sujeitas a revisões futuras ${ }^{246}$.

Ao afirmar que o mundo moderno não é dominado pela racionalidade estratégica, Habermas não pretende descartá-la. Ele reconhece que ela governa a economia e a burocracia estatal, mas afirma que isso não significa que isso também seja

\footnotetext{
${ }^{243}$ Meehan, J.

${ }^{244}$ Idem

${ }^{245}$ Idem.

${ }^{246}$ Idem
} 
verdade em todos os espaços de interação humana. Enquanto na economia, a progressiva racionalização gera mais opressão e rigidez, outros aspectos da vida ganharam com a modernidade a possibilidade de aumentar sua racionalidade comunicativa $^{247}$.

Sua concepção de racionalidade comunicativa, portanto, requer uma maior segmentação das esferas público e privado. Ele busca outras camadas em cada uma dessas esferas para diferenciar os espaços de incidência da razão comunicativa dos da razão estratégica. No entanto, embora distinga idealmente o campo de incidência da racionalidade estratégica da racionalidade comunicativa, Habermas admite que atualmente a racionalidade estratégica vem, progressivamente, invadindo espaços destinados à racionalidade comunicativa. Mas afirma que é preciso resistir a essa invasão. Embora reconheça que a possibilidade dessa resistência seja limitada pelos imperativos do próprio sistema que quer contestar ${ }^{248}$.

Para a teoria feminista, Habermas apresenta contribuições importantes: a possibilidade de uma concepção de igualdade que respeita a diferença e a problematização da dicotomia público-privado liberal que vem sendo apontada, desde a segunda onda do feminismo, como uma forma de legitimar as desigualdades de gêneros.

No entanto, há várias dificuldades de conciliar Habermas com a demanda feminista. A primeira refere-se ao fato de a sua divisão entre as esferas público e privado não levar em conta o processo de formação das identidades de gênero. $\mathrm{O}$ segundo, diretamente relacionado ao primeiro, está na separação entre questões de justiça e questões de bem. A desigualdade de gênero está profundamente relacionada a normas comportamentais substantivas, a estilos de vida, às especificidades culturais. Assim, buscar a igualdade sem aplicar princípios de justiça a essas questões não protege as desigualdades de gênero de questionamentos; .

No primeiro item deste capítulo será discutida a importante contribuição de Fraser ao problema do público e do privado em Habermas, formulada em seu artigo "What's critical about critical theory?".

\footnotetext{
247 idem

248 idem
} 
No segundo item, será discutida a crítica de Benhabib à separação entre questões de justiça e questões de bem. Ela afirma que a preocupação de Habermas em não permitir que a igualdade seja substantiva e excludente o leva a considerar que as questões de bem são de interesse privado e as questões de justiça, de interesse público. No entanto, Benhabib afirma que o universalismo procedimental habermasiano pode ser aplicado às questões de bem, sem risco de comprometer o respeito à diferença. Esse é o projeto de Benhabib que a leva a formular o seu conceito de "universalismo interativo $^{, 249}$.

Esse universalismo, porém, é criticado por Fraser e Linda Nicholson. Em seu artigo "Criticsm without Philosophy", as autoras buscam uma concepção de igualdade que não implique o universalismo, nem mesmo o universalismo interativo de Benhabib. No entanto, elas se propõem a fazer isso sem perder de vista a necessidade de a crítica não se fragmentar, a ponto de não ser capaz de questionar desigualdades estruturais. A proposta de ambas é de uma concepção de igualdade que justifique uma crítica localizada, que é menos abrangente do que a de Benhabib, mas também não tão fragmentada quanto a de Butler.

O objetivo deste capítulo é analisar se essas concepções de igualdade no mundo moderno pós-convencional podem responder às críticas de Butler e assim estar na base de um modelo teórico que seja capaz de produzir identidades provisórias e inclusivas, mas suficientemente representativas para motivar a organização de movimentos sociais em seu nome.

\section{I) O Público, o privado e a justiça}

O movimento feminista já teve a dicotomia liberal público-privado como aliada. A divisão entre o espaço da igualdade e do da diferença funcionou como argumento para preservar a autonomia feminina em um espaço sem intervenção estatal, no qual podem gerir sua conduta livremente. Igualdade e diferença pareciam harmonicamente combinados. 
No entanto, os limites do liberalismo político para o feminismo se tornariam evidentes já em fins do século XIX. Elizabeth Cady Stanton, uma das principais vozes do feminismo liberal da época, foi alvo de críticas por reivindicar direitos para as mulheres isolando-as do contexto que restringe seu acesso ao trabalho e à participação política $^{250}$. Sem questionar a distribuição de tarefas e de poder na esfera doméstica, o feminismo liberal do século XIX encontrava suas próprias limitações.

Desde aquela época, a maior parte das críticas dirigidas ao feminismo liberal tem como alvo a dicotomia público/privado em sua versão clássica, com fundamento em Locke. Nessa vertente, a linha divisória entre o público e o privado separa a sociedade civil do Estado. A sociedade representa o espaço da liberdade pessoal, a esfera em que os indivíduos experimentariam a "independência perfeita" porque estão a salvo da coerção do Estado, restrita à esfera pública.

Além dessa, há ainda outra forma de distinguir o público do privado, segundo a qual os pólos opostos correspondem não à sociedade civil e ao Estado, mas ao social e ao pessoal. $\mathrm{Na}$ origem, essa foi uma distinção proposta pelo romantismo para se contrapor ao liberalismo, que não reservou nenhuma esfera para a intimidade. Os românticos afirmavam que mesmo a esfera social não libera o indivíduo de forças coercitivas, uma vez que as expectativas sociais constrangem os sujeitos a representarem papéis. O comportamento do indivíduo está, enfim, sob constante vigilância e julgamento também na esfera social ${ }^{251}$.

Os indivíduos, porém, precisam de tempo para si, precisam ter um espaço em que possam abandonar todos os papéis da vida civil, em que estejam protegidos do olhar e do julgamento do grupo (político e social) a que pertencem. A esse espaço chamaram de esfera pessoal ou íntima, na qual estão incluídas apenas as relações de amizade e de amor $^{252}$. A noção de intimidade foi traduzida pelos liberais como "direito à privacidade", cuja identificação com o liberalismo tornou-se intensa a ponto de ofuscar sua origem romântica ${ }^{253}$.

\footnotetext{
${ }^{250}$ Brysson, Valérie. Feminist Political Theory: London: Macmillan Press, 1992, pp. 36 e ss

${ }^{251}$ Rosenblum, N. Another Liberalism: Romanticism and the Reconstruction of Liberal Thought. Harvard University Press, Cambridge, Mass: 1987, p. 67.

${ }^{252}$ Rosenblum, N. Another Liberalism: Romanticism and the Reconstruction of Liberal Thought. Harvard University Press, Cambridge, Mass: 1987, p. 67.

${ }^{253}$ Benn, S e Gauss, G. Public and Private in Social Life. Croom Helm, Kent, 1983, pp. 53 e ss.
} 
As duas versões da dicotomia público/privado são problemáticas para o feminismo. A primeira, como foi dito acima, porque assume que soluções meramente formais, como o direito ao voto, são medidas suficientes para emancipar as mulheres de papéis subordinados. A segunda, por sua vez, porque resguarda da intervenção pública as relações amorosas, familiares e sexuais, que são os espaços em que a discriminação de gênero aparece mais freqüentemente.

As teorias feministas, por mais diversas que possam ser suas concepções de igualdade, têm de lidar, simultaneamente, tanto com a demanda pela reserva de um espaço de não interferência social e estatal na escolhas e na conduta individual das mulheres, como com a demanda da intervenção estatal na esfera privada, quando é preciso evitar ou coibir práticas sexistas de grupos sociais conservadores ${ }^{254}$.

As criminalizações da violência doméstica e, em particular, do estupro marital estão entre as discriminações de gênero que mais desafiam a dicotomia público/privado, em qualquer de suas versões. Afinal, mesmo na concepção mais restrita de privado do liberalismo de influência romântica, pode ser difícil justificar a intervenção estatal em relações conjugais que pertencem à esfera de intimidade ${ }^{255}$.

De outro lado, a fusão do público e do privado também apresenta problemas para o feminismo. Afinal, como defender, por exemplo, a liberdade sexual feminina ou o direito ao aborto se não houver limites à interferência estatal no controle do comportamento individual?

Uma concepção de igualdade de gênero tem de problematizar a dicotomia público-privado. Mas isso não significa, simplesmente, descartá-la. Além disso, ela deve também abarcar a diferença e as assimetrias de poder no espaço concreto de formação da identidade. Só assim é possível construir uma concepção de igualdade que contemple tanto as demandas da segunda quanto da terceira onda do feminismo.

A contribuição de Fraser nessa questão foi decisiva para a teoria crítica feminista, especialmente na que é influenciada por Habermas. Em seus artigos "Foucault on modern Power" e, especialmente, no What's critical about critical

\footnotetext{
${ }^{254}$ Ver Nussbaum, M. “The Feminist Critique of Liberalism” in Sex and Social Justice. Oxford: Oxford University Press, 1999, pp. 59-67.
} 
theory”, ela acusa Habermas de não inserir o poder, ao menos não suficientemente, nas relações familiares, que são as redes de interlocução em que o gênero é produzido.

Fraser examina o potencial crítico da teoria da ação comunicativa no que diz respeito às relações de gênero. Ela faz essa análise tendo em vista a forma como a vida e as tarefas familiares são incorporadas a esse modelo teórico. Seu ponto de partida são as duas distinções centrais na teoria habermasiana: 1) reprodução simbólica da sociedade e reprodução material da sociedade; 2) mundo da vida e sistema ${ }^{256}$.

A reprodução simbólica refere-se aos modos de reprodução da cultura e dos valores; enquanto a reprodução material consiste na reprodução do sistema capitalista $^{257}$. Na segunda distinção, o mundo da vida é o espaço em que a ação é socialmente integrada e o sistema é aquele em que a ação é estrategicamente motivada. Tanto o mundo da vida quanto o sistema se dividem em público e privado. Assim, as relações estratégicas e as socialmente integradas se darão tanto na esfera pública quanto na privada ${ }^{258}$.

Esse modelo, diz Fraser, é mais complexo do que a divisão público-privado clássica do liberalismo que o feminismo, mesmo o liberal, sempre criticou. Além disso, Habermas reconhece a interdependência entre o público e o privado, outra reivindicação feminista recorrente. Ele trata de dinâmicas de intercâmbio entre instituições e indica as formas como elas se complementam mutuamente, como suprem as necessidades uma das outras ${ }^{259}$.

O intercâmbio é sempre feito através de um meio e de um personagem. As esferas privadas do sistema e do mundo da vida (economia e família, respectivamente) relacionam-se por meio do dinheiro. A família supre a economia com força de trabalho, e irá consumir os produtos que serão produzidos. Assim, as trocas entre economia e a família serão feitas através das figuras do trabalhador e do consumidor ${ }^{260}$. As esferas públicas do sistema e do mundo da vida, por sua vez, relacionam-se por meio do poder. O espaço de participação política oferece lealdade, obediência e impostos em troca de

\footnotetext{
${ }^{255}$ Mackinnon, C.. Feminism unmodified: Discourses on Life and Law. Harvard University Press, Cambridge, Mass, 1987. , pp. 100 e ss.

${ }^{256}$ Fraser, N. "What's critical about critical theory" in Meehan, J. Feminists read Habermas.., p. 22 e ss.

257 Idem.

${ }^{258}$ Idem

${ }^{260}$ Idem, (PP. 32-33).
} 
resultados organizacionais e decisões políticas. A personagem que estabelece essa conexão é o cidadão e, no estado de bem estar social tardio, ele se transforma em cliente.

Habermas apresenta ainda outra contribuição para o feminismo. Ele concebe a família nuclear como uma instituição historicamente formada, surgida concomitantemente com o capitalismo e o estado administrativo. Assim, ele afasta o caráter natural e essencialista dos arranjos familiares ${ }^{261}$.

Há, porém, várias desvantagens nesse modelo. Segundo Fraser, os papéis do trabalhador-consumidor e do cidadão-cliente contêm um subtexto de gênero que Habermas negligencia. A ligação entre o sistema econômico e a família não é apenas o dinheiro, é uma identidade de gênero. O homem é prioritariamente identificado como trabalhador, e a mulher como consumidora. Ainda que possam assumir ambas as posições, eles o fazem com algum estranhamento. Há uma diferença qualitativa na forma de inserção da mulher no mundo do trabalho, bem como há essa diferença em relação à incorporação do papel do consumidor. A mulher trabalhadora ocupa mais fácil e freqüentemente posições de trabalho de assistência, que se assemelham aos trabalhos domésticos; enquanto a identidade masculina é fortemente determinada pelo papel de provedor $^{262}$.

Além disso, em Habermas, não há menção à tarefa de criar filhos. Essa omissão mascara a relevância central do gênero para a estrutura institucional do capitalismo clássico. E isso poderia ter levado à explicitação da importância da identidade de gênero como "meio de intercâmbio" entre as esferas privadas do sistema e do mundo da vida.

A interação entre as esferas públicas também está marcada pelo gênero. A figura do cidadão, que estabelece essa ligação, é também masculina. Para Habermas, o cidadão corresponde ao participante no debate político e na formação da opinião pública. Mas a mulher, diz Fraser citando Pateman, tem sua opinião sempre reinterpretada, não é dona de seu próprio discurso. Nos casos de estupros isso fica evidente, já que é comum que a defesa sustente que "quando a mulher diz não, ela quer dizer sim",263. As ambigüidades atribuídas ao discurso feminino situam a mulher em uma posição inferiorizada na rede de interlocução. Isso coloca em xeque sua autonomia, sua capacidade de construir e reconstruir seu próprio self.

\footnotetext{
${ }^{262}$ Idem.
} 
Para Fraser, depois de explicitado o subtexto de gênero, a teoria de Habermas pode funcionar para justificar a igualdade de gênero. Benhabib, porém, acredita que isso não é suficiente. Para que a teoria habermasiana seja útil para o feminismo é preciso aplicar princípios morais universais tanto a questões de justiça quanto a questões de bem

\section{II) Questões de boa vida e questões de justiça.}

A distinção entre questões de justiça e questões de boa vida deve-se à busca de princípios universais de moralidade que reflitam concepções de justiça formais e imparciais, ou seja, concepções de justiça cuja universalidade seja capaz de respeitar modos de vida particulares ${ }^{264}$.

Nessa visão, o cuidado e a generosidade entre os seres humanos são questões às quais não devem ser aplicados princípios de justiça porque não podem ser generalizados $^{265}$. São sentimentos dirigidos ao grupo com o qual temos relações afetivas. O amor entre amigos, amantes e familiares, portanto, não pode servir de base de justificação moral para questões de justiça.

Benhabib, porém, observa que essa separação é contra-intuitiva. Por mais que as pessoas possam ter interesse e se envolver apaixonadamente em questões políticas e econômicas, é nas relações pessoais que surgem os dilemas morais mais profundos ${ }^{266}$.

Benhabib sustenta que o desenvolvimento de seres individuais autônomos e moralmente competentes tem relação tanto com a dependência originária, quanto com o dever de cuidado que temos pelos outros. Assim ela conclui que, tanto a justiça como o cuidado são essenciais para o desenvolvimento da autonomia do sujeito.

Nas redes de interlocução, desde o início, estamos concretamente envolvidos por necessidades, vulnerabilidades, emoções e desejos ${ }^{267}$. O contato com o outro, enfim, tem ao mesmo tempo a face da dependência e da responsabilidade pelo outro.

\footnotetext{
${ }^{263}$ Idem.

${ }^{264}$ Idem, p. 184.

265 Allen, p. 157 ver ref Benhabib

${ }^{266}$ Benhabib. " The debate over women and moral theory revisited" in Situating the Self, p. 185.

${ }^{267}$ Idem.
} 
Concepções de moralidades universalistas de justiça como a de Habermas ${ }^{268}$ enfatizam a dignidade, nosso valor como sujeitos morais capazes de escolhas, deixando de lado nossa vulnerabilidade enquanto "selves corporificados" ("bodily selves"). Essa vulnerabilidade, que está conosco desde o nascimento, permanece durante toda a vida e estará presente no desenvolvimento moral do sujeito no estágio pós-convencional. Assim, o erro de separar concepções de bem das de justiça decorre do fato de as formações do self e da autonomia do indivíduo estarem vinculadas, simultaneamente, a questões de justiça e de cuidado ${ }^{269}$.

$\mathrm{Na}$ teoria feminista, corporificação e contextualização são quase sempre indissociáveis, especialmente depois da influência da terceira onda, uma vez que o masculino e o feminino são atributos impressos na concretude do corpo. Ao trazer a corporificação para os debates sobre igualdade e diferença, o feminismo introduziu nessas reflexões o papel de nossa vulnerabilidade na formação da subjetividade ${ }^{270}$. Benhabib sustenta que a corporificação é o elemento que falta às teorias universalistas de justiça como a de Habermas para que as relações de poder sejam adequadamente incorporadas ao processo de construção da identidade ${ }^{271}$.

Enfim, em Benhabib, a concretude do sujeito implica sua corporificação (“embodiness"). A corporificação, por sua vez, remete às relações de dependência, cuidado e mutualidade na qual toda criança é socializada ${ }^{272}$. Sem levar isso em conta, o sujeito desvincula-se de suas identidades concretas, entre as quais, a identidade de gênero. Assim, ela conclui que tanto a Butler como a Habermas falta uma concepção de interdependência, mas por razões totalmente diferentes. Em Butler essa falta se deve ao fato de o ser humano ser apenas dependente, e em Habermas, de ser excessivamente independente.

Inspirada em Carol Gilligan, Benhabib procura vencer a barreira entre questões de boa vida e de justiça com a idéia de ética do cuidado ${ }^{273}$. Segundo Gilligan, há uma

\footnotetext{
${ }^{268}$ Benhabib reconhece que Habermas não é puramente racionalista, já que para ele a solidariedade (cuidado) e a autonomia (justiça) estão ligados por uma forma de vida compartilhada intersubjetivamente. No entanto, embora para ele essas dimensões das relações humanas sejam ligadas, elas continuam sendo separadas em categorias diferentes, que impedem que sua concepção de sujeito seja corporificada, como querem as feministas. Benhabib, Idem, p. 190. Ver também Fraser, N. "what's critical about critical theory" e Meehan, J. (ver referências em feminists read Habermas.

${ }^{269}$ Idem.

${ }^{270}$ Benhabib, S. “ The debate over feminism and morality revisited”., p. 87.

${ }^{271}$ Allen, p. 157 ver ref Benhabib

${ }^{272}$ Idem, p. 90.

${ }^{273}$ Gilligan, Carol. In a different Voice, p. 135
} 
"moralidade feminina", que é mais sensível aos particularismos, enquanto a "moralidade masculina" é universal e neutra. Para ela, as teorias da justiça não levam em conta que a aplicação de princípios morais exige que o sujeito seja sensível às necessidades dos outros.

Kymlicka cita um exemplo que esclarece esse argumento. Um julgamento de crime por negligência implica avaliações que vão além da aplicação de princípios. Nesse caso, são necessárias também competências morais relacionadas à empatia pelo outro. Os casos em que a negligência dever ser criminalizada são definidos com base em princípios morais universais, mas a definição do que é negligência supõe a responsabilidade pelo outro, o dever de cuidado ${ }^{274}$.

Embora Benhabib discorde da idéia de Gilligan de que há uma "moralidade feminina" e outra "masculina", ela afirma que Gilligan oferece recursos para superar a dicotomia entre questões de justiça e de boa vida. Para ela, a tese de Gilligan não leva necessariamente à rejeição de princípios universalistas de justiça, mas apenas à introdução da solidariedade como um elemento necessário no processo de construção intersubjetiva da autonomia do sujeito. Ela afirma que Gilligan não explica a ética do cuidado como o oposto à ética da justiça. Sua preocupação é antes integrá-las ${ }^{275}$.

Integrar a ética do cuidado e a ética da justiça significa não considerar a primeira como algo particular, referente somente às nossas relações afetivas. A solidariedade, assim, deve ser entendida como responsabilidade pelo cuidado com o outro, é um sentimento de cuja existência depende a formação da autonomia de cada participante da rede de interlocução. Está, portanto, diretamente relacionado com as condições de possibilidade do processo de construção das identidades em sociedades pósconvencionais $^{276}$.

\footnotetext{
${ }_{274}{ }_{13}$ KYLIMCKA,W. Filosofia Política Contemporânea. p.338.

${ }^{275}$ A tese de Gilligan sobre a relação entre a ética do cuidado e a ética da justiça foi muitas vezes interpretada como uma divisão estanque entre feminino e masculino, retomando uma essencialização das identidades de gênero. Enquanto o masculino corresponde ao geral, ao universal, à justiça; o feminino se define pela receptividade, pela responsabilidade e pelo cuidado. Nel Nodding é uma das autoras que faz essa interpretação. Benhabib, porém, salienta que essa formulação não pode ser derivada do argumento de Gilligan. Segundo Benhabib, Gilligan procura superar a dicotomia cuidado, justiça, particular-universal; buscando integrá-las no raciocínio e o julgamento moral. Sobre essa interpretação do trabalho de Gilligan ver Flanagan e Jackson. "Justice, care, and Gender: The Kohlberg-Gilligan Debate Revisited", Ethics 97 (;april 1987), PP. 662-637. Sobre a posição contrária, ver Noddings, Nel. Caring, A feminine Approach to Ethics an Moral Education (Berkeley: University of California Press, 1984).

${ }^{276}$ Benhabib, The debate over women and moral theory revisited, p.182.
} 
Benhabib afirma que Habermas não conseguiu integrar adequadamente a solidariedade e a justiça porque descartou muito rapidamente um dos insights mais importantes de Gilligan e de outras feministas: "a de que somos crianças antes de sermos adultos "277.

Em Habermas, a formação da identidade do ego permanece intacta no chamado estágio moral convencional, ou seja, na fase em que o indivíduo assimila as normas morais de seu contexto. A identidade pessoal, por sua vez, forma-se quando o sujeito entra na fase da moralidade pós-convencional, ou seja, quando aprendeu a problematizar as pretensões normativas e a oferecer argumentos que sustentam seus questionamentos no debate com os outros. Nessa fase pós-convencional, a identidade do ego já está constituída, mas o desenvolvimento moral do sujeito ainda está em andamento.

Gilligan e Kohlberg travaram um debate sobre a ética do cuidado. Segundo Gilligan, há um estágio do desenvolvimento moral que Kohlberg não considera. Esse estágio está relacionado à vinculação que o adulto moralmente maduro estabelece entre a justiça e o cuidado no sentimento de responsabilidade pelo outro. A origem desse sentimento está na vulnerabilidade, na dependência absoluta que temos da pessoa responsável por nós em nossos primeiros anos de vida. Na sua intervenção no debate entre Gilligan e Kohlberg sobre a ética do cuidado, Habermas afirmou que o desenvolvimento do ego não deve ser confundido com o desenvolvimento moral, reafirmando a idéia de que na fase pós-convencional o sujeito já tem o seu ego constituído $^{278}$.

Habermas não analisa o impacto que relações de dominação no estágio convencional da formação do self pode produzir no auto-respeito como no respeito aos demais participantes ${ }^{279}$. Ele não analisa o processo de constituição das concepções de bem e as implicações que ele traz para a constituição da identidade na fase que chama de convencional. Mas, diz Benhabib, é esta relação que dará as condições para o reconhecimento mútuo na fase na pós-convencional ${ }^{280}$.

\footnotetext{
${ }^{277}$ Benhabib, “ The debate over women and moral theory revisited.., p. 188.

${ }^{278}$ Habermas. "Moral Development and ego identity” in Communication and the Evolution of Society. (trans) McCarthy, T. Boston: Beacon Press, 1979, p. 90 e ss.

${ }^{279}$ Honneth, A. "Integrity and Disrespect: Principles of a Conception of Morality Based on the Theory of Recongition”, pp. 189 in Political Theory, Vol.20, n. 2, May 1992, pp. 190 e 191.

${ }^{280}$ Meehan, J. "Atunomy, Recognition and Respect”, p. 245 in Meehan, J. (ed). Feminists read

Habermas: gendering the subject of discourse. New York: Routledge, 1995.
} 
Para compatibilizar a aplicação de princípios universais a concepções de bem com o respeito à diferença, Benhabib propõe substituir a separação entre questões de boa vida e questões de justiça pela distinção entre a moral e a justificação moral ${ }^{281}$.

Nenhum dos requisitos impostos pelo universalismo procedimental é incompatível com a sua aplicação a questões de bem. A justificação dos princípios morais exige o respeito à dignidade do outro e o compromisso de aceitar normas válidas intersubjetivamente geradas por participantes de discursos práticos, que manifestam respeito moral mútuo. Esse respeito mútuo é manifestado em deliberações em que cada um se coloca na posição do outro, de um outro que é, ao mesmo tempo, concreto e generalizado $^{282}$.

As restrições impostas pela ética do discurso referem-se ao tipo de justificação que emerge de um modelo de deliberação individual e coletiva. Isso não requer a definição de um campo moral limitado, pois os procedimentos não geram resultados específicos. Eles definem apenas o modo como as justificações morais válidas serão concebidas, tanto nos casos em que as justificações referem-se a questões de boa vida quanto à questões de justiça ${ }^{283}$.

Benhabib dá o seguinte exemplo de como os princípios universais podem ser aplicados à ética do cuidado.

"Há uma diferença entre dizer que 'membros de famílias judias, irlandesas ou italianas devem apoiar e cuidar uns dos outros e a idéia de que não importa qual seja a sua ascendência, um mundo em que as famílias, ou núcleos de pessoas semelhantes a famílias devem apoiar e cuidar uns dos outros. O último caso é de uma pretensão moral universalizável, enquanto o primeiro permanece uma articulação etnocêntrica de uma moralidade de grupo que tem dois lados: solidariedade de grupo pode ser atingida à custa do descuido moral e desprezo por indivíduos que são membros de outros grupos." 284

Enfim, Benhabib se opõe à distinção entre questões de justiça e questões de boa vida porque vê nessa divisão um sintoma do racionalismo iluminista, que considera as questões de justiça o núcleo duro da ética universalista, capaz de abarcar diferenças. No entanto, a teoria feminista, desde a terceira onda, vem mostrando que esse

\footnotetext{
${ }^{281}$ Benhabib, The debate over women and moral theory revisited" in Situating the Self, p. 186.

282 Idem.

283 Iem

${ }^{284}$ Idem, p. 188.
} 
universalismo tem sido cego às diferenças de gênero, justamente porque não incide sobre o espaço de interlocução em que as identidades de gênero são construídas. Assim, concepções de justiça como essas permanecem indiferentes às desigualdades de gênero.

Apesar dessa crítica, Benhabib não pretende abrir mão do universalismo. Ao contrário, sua intenção é estender seu âmbito de incidência. Mas ela faz isso atenta para os riscos da repressão à diferença. Sua solução é ampliar o escopo do universalismo procedimental de Habermas. Seu método visa à conciliação entre o universal e o particular mesmo quando o dilema moral refere-se a concepções de bem específicas.

As questões de bem também podem ser objeto de discussão e julgamento. Mas isso não significa que o diálogo exija que os participantes tenham laços afetivos entre si. Não é preciso que sejamos emocionalmente afetados pelo ponto de vista do outro para aceitá-lo. Implica apenas a capacidade de pensar da perspectiva de todos, ou seja, a capacidade de saber ouvir os outros e, mesmo quando o outro estiver ausente, poder imaginar um diálogo em que ele apareça como parceiro. As condições do diálogo moral, enfim, estão relacionadas ao "princípio do pensamento alargado"285.

Em Kant, o "pensamento alargado", ou seja, a capacidade de se colocar no lugar do outro, é um modo de evitar que a reflexão permaneça circunscrita à perspectiva individual. Hannah Arendt aproveita essa idéia para introduzir na política a capacidade de assumirmos a perspectiva do mundo, de tomarmos conhecimento dos vários pontos de vista pelos quais um assunto deve ser visto e avaliado. Essa capacidade resulta do interesse no mundo e nos seres humanos, e da capacidade de definir a fronteira entre o "eu " e os "outros"286.

Enfim, aplicar princípios de justiça a questões de bem não exige que as pessoas estendam seus sentimentos de afeto a todos os participantes da rede de interlocução. Não precisamos sentir por todos o amor que temos por amigos, familiares e amantes. Esses sentimentos são, de fato, particulares. Mas isso não significa que os valores que permeiam essas relações não possam ser universalizados.

$\mathrm{O}$ "princípio do pensamento alargado" permite que o cuidado e a responsabilidade pelo outro assumam uma dimensão mais ampla. Ele pode ser entendido, como diz Arendt, como um "amor pelo mundo", que se traduz na

\footnotetext{
${ }^{285}$ Arendt, H. " The crisis of culture" in Between past and future: Six exercises in Political Thought. New York: Meridian, p. 221.

${ }^{286}$ Benhabib, “Rethinking Arendt's Political Theory” in The Reluctant modernism of Arendt, p. 191.
} 
capacidade de nos colocarmos no lugar do outro sem projeção, idealização ou distorção ${ }^{287}$.

Finalmente, a superação da divisão entre questões de bem e de justiça requer ainda uma relação de interdependência entre o público e o privado que Benhabib também encontra em Hannah Arendt ${ }^{288}$. O privado em Arendt tem um significado bem específico. É o espaço em que os seres humanos preservam sua intimidade ${ }^{289}$. É a esfera que atende à necessidade de preservarmos alguns aspectos da vida íntima e doméstica da exposição pública ${ }^{290}$. Para ela, a distinção entre privacidade e intimidade é uma criação moderna, tanto quanto a transformação do político-público em social-público. Ao colocar os indivíduos em situações de anonimato na esfera do mercado, a modernidade criou o culto à individualidade, à singularidade, à autenticidade e à harmonia psíquica do self.

Essa individualidade é condição para a exposição pública e vice-versa. Uma vida que é totalmente exposta no espaço público, leva a um total descentramento do self. Para Arendt, nossa subjetividade depende de um abrigo onde possamos esconder nossa intimidade. Do contrário, nós nos tornamos apenas "sombras pelas ruas" ${ }^{291}$.

O abrigo introduz a dimensão do cuidado ao lado da autonomia. A intimidade e a domesticidade contribuem ao mesmo tempo para o cuidado com a sobrevivência física como para o desenvolvimento da autonomia. A conseqüência disso é reinterpretar o cuidado com uma questão de justiça. Proteger o direito das crianças de serem criadas com respeito pela sua integridade física e moral, condenar a violência doméstica, inclusive o estupro marital, é uma exigência do respeito à autonomia do indivíduo mesmo nas relações humanas mais íntimas ${ }^{292}$.

Benhabib reconhece que expande consideravelmente as categorias de Arendt. Mas ela o faz sem distorcê-las. A idéia de Arendt de que a recuperação do público requer uma esfera privada robusta, sob pena de o self tornar-se um estranho para si mesmo, atende a uma das demandas mais insistentes da teoria feminista: a superação da

\footnotetext{
${ }^{287}$ Idem, p. 192 e Arendt, The crisis of culture, 220 e 221.

${ }^{288}$ Arendt, H. The crisis of culture, p. 48

${ }^{289}$ Ver Arendt, H. Te crisis of culture. Benhabib, The reluctant modernism of Hannah Arendt e

Nicholson, L. "Bringing it all back home: reason in the twilight of foundationalism (cap.7) in Nicholson,

L. The play of reason: from modern to the post modern. Cornel University Press, 1999, p. 124 e ss.

${ }^{290}$ Arendt, a condição humana e Benhabib

${ }^{291}$ Ide, p. 213.

${ }^{292}$ Benhabib. The reluctant modernism of Hannah Arendt
} 
divisão estanque entre o público e o privado. E faz isso, preservando um espaço para a intimidade ${ }^{293}$.

A interdependência entre o público e o privado põe fim à divisão entre questões de justiça e de boa vida. No entanto, para submete-las a princípios de justiça universais é preciso ir além de Arendt. É preciso desvelar a filosofia moral implícita em sua teoria.

Para isso, Benhabib propõe um "universalismo interativo". Ela incorpora os princípios do respeito universal e da reciprocidade igualitária de Habermas como a referência filosófica do ponto de vista moral. Mas ela considera que esses princípios não são os únicos que permitem a avaliação da competência moral dos atores no estágio pós-convencional, nem tampouco são pressuposições transcendentais inequívocas que cada ator racional deve adotar. Esses princípios resultam de um "equilíbrio reflexivo" 294 , que nos permite analisar e julgar a moral de cada cultura. Com o equilíbrio reflexivo, chegamos a uma descrição substantiva das pressuposições morais da modernidade ${ }^{295}$.

Enfim, para Benhabib os princípios morais universais emergem de contextos particulares. Ela admite que cada comunidade interpreta a estrutura formal da competência moral do estágio pós-convencional de modos distintos. No entanto, ela afirma que o universalismo procedimental fornece um modo de avaliar os valores morais de cada cultura e ainda assim preservar o respeito à diversidade de concepções de boa vida.

\footnotetext{
${ }^{293}$ Eichmann é um exemplo de self descentrado, incapaz de pensar por si mesmo. A ele nada mais restou do que sua condição de funcionário do regime nazista. Arendt chega a fazer um paralelo entre sua condição de judia alemã exilada (descolada no mundo) com o do funcionário medíocre, que está deslocado de si mesmo. Enquanto exilada, Arendt foi deslocada da esfera pública e Eichmann, deslocado da sua intimidade. Mas em ambos os casos o resultado é a destruição do self. Sem espaço público, não temos direito a ter direitos e com isso não somos mais reconhecidos com humanos, conforme diz Arendt em sua crítica aos direitos humanos. Do mesmo modo, sem espaço de intimidade, nós nos tornamos meros autômatos, capazes de ações conflitantes com nossas convicções de bem mais profundas. Colocar referência

${ }^{294}$ Explicar equilíbrio reflexive em Rawls

${ }^{295}$ Benhabib, S. Situating the Self, p. 30.
} 


\section{III) Igualdade sem Universalismo}

Fraser está de acordo com Benhabib no que se refere ao questionamento da fronteira entre questões de bem e questões de justiça. Sua estratégia para ultrapassar essa distinção, porém, segue outro rumo. Fraser propõe-se a reconciliar as categorias do reconhecimento (geralmente relacionada a questões de bem) e a da redistribuição (relacionada à justiça), trazendo a ética para o campo da justiça, assim como faz Benhabib, mas não a ponto de torná-las indistintas. Fraser considera que há casos em que a avaliação ética é inevitável, mas sustenta que há como adiá-las tanto quanto possível $^{296}$.

Apesar de criticar Habermas por considerar as demandas feministas particularistas, Nancy Fraser discorda também da proposta de Benhabib de aplicar princípios universais de justiça a questões de bem. Em artigo escrito em co-autoria com Linda Nicholson, Fraser propõe uma "virada pós-moderna na teoria feminista". Elas seguem os passos de Butler para se afastarem de princípios universalistas. No entanto, Fraser e Nicholson afirmam que desigualdades estruturais como as de gênero exigem uma concepção de igualdade abrangente. Nisso, elas se afastam de Butler ${ }^{297}$.

Uma igualdade abrangente não precisa ser universalista. Fraser acredita que é possível formular teorias sociais e políticas que identificam as desigualdades de gênero em diversas culturas, mas que não estão fundamentadas em princípios universais. Essas teorias são um ponto médio entre as macronarrativas universalistas e as narrativas empíricas e localizadas. Elas são "quase macronarrativas"298.

As "quase macronarrativas" aproveitam os insights pós-modernos, mas preservam um grau de generalidade para formular uma teoria feminista. A crítica feminista pós-moderna deve permanecer teórica. Ela não abandona as ferramentas teóricas utilizadas em problemas políticos abrangentes. Para Fraser e Nicholson, mesmo

\footnotetext{
${ }^{296296}$ Fraser, Nancy. "Reconhecimento sem ética_”. Lua Nova, São Paulo, 2007, p.103

${ }^{297}$ Fraser, N. e Nicholson, L. " Social Criticism without Philosophy" in Nicholson, L. The play of reason: from the modern to the post-modern, p. 105

${ }^{298}$ Fraser, N. e Nicholson, L. 'Social Criticism without Philosophy;' in Nicholson, L. The play of reason: from the modern to the post-modern, p. 106
} 
depois de renunciar ao universalismo, é possível formular uma teoria feminista, inclusive uma teoria feminista pós-moderna ${ }^{299}$.

A vantagem da "quase metanarrativa" está no fato de ser suficientemente abrangente para abarcar análises transculturais e trans-históricas. Mas essa análise deve ser comparativa, ao invés de universalista. Seu foco deve estar nas mudanças e contrastes entre diferentes narrativas; e não em princípios universais ${ }^{300}$.

A teoria feminista pós-moderna de Fraser e Nicholson rejeita a "mulher" como uma categoria universal e uniforme. Em seu lugar, ambas apresentam uma concepção de identidade social complexa, que articula gênero, classe, etnicidade e orientação sexual $^{301}$. Para elas, portanto, a crítica feminista deve substituir categorias unitárias reunidas em nome de uma identidade comum por categorias múltiplas formadas por alianças sobrepostas, que não podem ser reduzidas a uma definição essencialista e estável $^{302}$.

Enfim, Fraser e Nicholson afirmam que o feminismo deve resistir à unificação. Ele deve permanecer plural. Essa é a atitude que o feminismo deve ao pós-modernismo. Para as autoras, é no paradigma pós-moderno que a teoria feminista deve buscar recursos para a crítica social. No entanto, essa crítica deve ser abrangente a ponto abarcar uma solidariedade ampla no movimento feminista entre as suas várias formas de expressão e suas várias intersecções com outras demandas sociais ${ }^{303}$.

A crítica sem "Filosofia" é mais sociológica do que a de Benhabib. É uma crítica focada na variação dos conceitos e de suas justificações no espaço e no tempo. No entanto, isso não significa que adotem um método meramente descritivo. Não significar reduzir a análise teórica à descrição do senso comum em uma determinada comunidade $^{304}$.

Privilegiar o foco na variação histórica e social dos princípios morais funciona com um constante alerta contra argumentos dedutivos que determinam em caráter

\footnotetext{
${ }^{299}$ Idem, p. 114.

${ }^{300}$ Idem.

${ }^{301}$ Idem.

302 Idem, p. 115.

${ }^{303}$ Idem.

${ }^{304}$ Nicholson, L. “ Bringing it all back home: reason in the twilight of foundationalism” PP. 120 e 121
} 
definitivo o significado de "racionalidade", "filosofia", "ciência", "mulher"; etc. Desse modo, evita-se o autoritarismo da razão a que Butler e Foucault se referem ${ }^{305}$.

No entanto, questionar o poder da razão para justificar princípios universais sempre levanta o risco do relativismo. Se os princípios forem sempre contextualizados, o risco de um conflito entre princípios ser insolúvel é maior. Afinal, sem um princípio universal, nossa avaliação não pode ser feita de uma perspectiva externa; não podemos olhar de um ponto de vista eqüidistante para os princípios em conflito ${ }^{306}$.

De fato, diz Nicholson, há situações em que não é possível solucionar conflitos acerca de princípios específicos. Isso significa que muitas vezes simplesmente não podemos provar que uma ação é correta ou incorreta. Mesmo imoralidades que parecem óbvias, como as ações de Hitler, não escapam dessa limitação. A razão não nos fornece, ao menos não sempre, um meio de justificar racionalmente nossos julgamentos morais $^{307}$.

No entanto, Nicholson sustenta que admitir essa limitação não leva ao relativismo epistemológico. Reconhecer os limites da racionalidade não é o mesmo que dizer que todas as verdades são equivalentes. Isso implica apenas admitir que nem sempre podemos fornecer uma justificativa racional convincente acerca daquilo que nos parece evidente. Essas situações são reais e não devem ser obscurecidas sob pena de reforçarmos o vínculo entre razão e poder ${ }^{308}$.

Habermas também admite essa limitação. Sua distinção entre questões de bem e questões de justiça funciona exatamente para definir o campo em que a justificação racional pode incidir e aquele em que as divergências são incomensuráveis. No entanto, essa divisão mostrou-se problemática para o feminismo. Quanto à isso, Fraser, Nicholson e Benhabib estão de acordo ${ }^{309}$.

Conforme já foi dito, Benhabib afirma que embora não haja um critério aritmético para hierarquizar valores, podemos avaliar a capacidade de "pensamento alargado" de cada participante do diálogo. É essa capacidade que nos permite definir a

\footnotetext{
305 Idem, p. 123.

${ }^{306}$ Idem.

${ }^{307}$ Idem

${ }^{308}$ Nicholson, L. "Bringing it all back home”, p. 124.

${ }^{309}$ Fraser, N. "What's critical about critical theory", p.
} 
moralidade ou imoralidade dos valores e hierarquizar os dilemas e as injustiças. Equiparar um pequeno contratempo com a perda do emprego soa irracional. No entanto, isso não significa que possamos justificar essa irracionalidade em um critério que defina a medida exata do certo e do errado ${ }^{310}$. Mas a capacidade de exercer o "pensamento alargado" poderá ser medida em qualquer caso. Tanto quando a situação envolve questões de bem como questões de justiça"311.

Para Nicholson, a proposta de Benhabib é insuficiente porque não contempla a possibilidade de o entendimento ser impossível. Para ela, Benhabib continua apegada à crença em um princípio universal capaz de resolver todos os conflitos. Sem dúvida, diz Nicholson, essa é uma crença reconfortante, mas não é real. Os dilemas morais podem, sim, ser insolúveis. No entanto, assim como os acordos são provisórios, a impossibilidade do acordo também é. Por isso, perder a fé em princípios universais não leva necessariamente a um relativismo cínico. Cito:

"Nós gostaríamos de acreditar em princípios, inerentes ao universo ou, como diz Habermas, ao discurso ou, como diz Benhabib, ao horizonte cultural da modernidade, que podem ser chamados para nos salvar da condição de pecadores, animais e brutos do período pré-moderno. Do mesmo modo que diferentes religiões tentaram dar a deus uma face específica, diferentes filósofos tentaram dar um conteúdo específico a esses princípios. O problema, no entanto, é que embora muitos de nós fiquemos aliviados com a perspectiva da salvação, nós também queremos o rosto de nosso salvador, ou o conteúdo de nossos princípios elaborados de açodo com nossos próprios valores e desejos. Salvação não coexiste bem com diversidade. Depois de reconhecermos esses conflitos, eu voto pela ênfase na diversidade(...). Confiar na contingenência dos recursos não nos preserva de rupturas na comunicação e de agirmos como brutos, mas, novamente, nenhuma crença na salvação tampouco atingiu esse objetivo" ${ }^{, 312}$.

Em suma, para Fraser e Nicholson é possível abdicar da universalidade e ainda assim evitar o relativismo, bem como a excessiva fragmentação da crítica pós-moderna. Elas se assumem como pós-modernas na sua oposição ao universalismo, mas formulam

\footnotetext{
${ }^{310}$ Benhabib, " the generalized and the concrete other", ..Nicholson, p. 125

${ }^{311}$ Nicholson, p. 126.

${ }^{312}$ Idem, p. 128.
} 
uma concepção de crítica social mais abrangente, capaz de questionar desigualdades estruturais. A "quase meta-narrativa" representa o meio termo entre a contextualização pós-moderna e a igualdade moderna. Sua função é manter a crítica sempre atenta ao espectro do universalismo bem como ao da excessiva fragmentação. Ambos são perigos que obscurecem e reforçam as desigualdades sociais; por isso a teoria feminista deve evitá-los a todo custo.

\section{II) Igualdade e Inclusão}

O processo de construção do sujeito está aqui também na base da divergência entre o paradigma moderno e pós-moderno. Apesar da influência de Habermas no pensamento de Fraser, ela adota a concepção de self performativo de Butler a fim de colocar mais ênfase nas assimetrias nos espaços sociais em que a identidade se constitui. Essa escolha repercute na sua concepção de igualdade.

Fraser afirma que em Habermas há um modelo teórico que permite conciliar igualdade e diferença. Ela está mais próxima de Habermas no que se refere à estratégia de evitar que princípios universais oprimam determinados modos de vida. Embora sustente que a dicotomia entre justiça e questões de bem na teoria habermasiana contribui para mascarar as desigualdades de gênero, ela vê a origem desse problema em um excessivo universalismo.

Enquanto Fraser se propõe a restringir o alcance do universalismo, Benhabib sugere a sua ampliação. Benhabib, porém, recorre à interpretação que Arendt faz do "pensamento alargado" kantiano para evitar um recuo ao universalismo cego às diferenças. O "pensamento alargado" é um procedimento que funciona como critério para distinguir o moral do imoral, o bom do mau.

A discordância de Fraser e Nicholson em relação a essa idéia de Benhabib resulta da adoção da concepção de sujeito pós-moderno. As três autoras autoras procuram de algum modo conciliar a assimetria real com a igualdade ideal, mas Fraser e Nicholson colocam mais ênfase na primeira, e Benhabib, na segunda.

A ênfase na igualdade leva Benhabib a supor que os conflitos morais sempre podem ser solucionados por meio do diálogo. Essa ênfase, porém, não é ingênua a ponto de negar as assimetrias reais. Ao contrário, ela procura destacar as desigualdade 
concretas quando afirma que no diálogo devemos assumir não apenas nossa perspectiva particular, mas também a do outro concreto e generalizado. $\mathrm{O}$ outro concreto, o interlocutor real, está em uma posição específica. Essa posição está marcada por desníveis de poder. Mas em Benhabib esses desníveis podem ser superados pelo recurso a um princípio universal. A concepção de self narrativo de Benhabib a permite destacar o sujeito de seu meio. Ele pode se exilar de seu contexto e analisá-lo de um ponto de vista externo. Mas isso não significa torná-lo abstrato novamente. Esse distanciamento é possível pela adoção da perspectiva do outro generalizado que se combina com a do outro concreto e de sua própria posição na sociedade.

A "pluralidade" e a "singularidade" em Arendt são as ferramentas que permitem a Benhabib conciliar igualdade e diferença. Ela tematiza o que Arendt não problematizou: a filosofia moral que está por trás das condições da formação intersubjetiva da identidade.

O self pós-moderno em Fraser e em Nicholson não permite esse distanciamento. O sujeito constituído pelo poder jamais se distancia de seu meio. Por isso, para elas os princípios universais, que exprimem um olhar externo e panorâmico de cada contexto, são meras reproduções das relações de poder.

Fraser e Nicholson, porém, querem ir além de Butler. Elas estão comprometidas com a função propositiva da teoria crítica, e nisso elas identificam a fragilidade do pósmodernismo. Uma concepção de igualdade de gênero que oriente o movimento feminista é possível e indispensável para a crítica social. Mas essa crítica não requer uma "Filosofia". A "quase macro- narrativa" cumpre a função de estabelecer um padrão para avaliar as questões de bem, sem subordiná-las a um princípio universal.

Em Fraser, enquanto as questões de bem são avaliadas com base em "quase macro narrativas", as questões de justiça continuam subordinadas a um princípio de moralidade universal, " a paridade de participação política”. Isso significa que Fraser não abdica da distinção entre questões de bem e de justiça. Embora sua distinção seja menos marcada do que em Habermas, ela insiste na necessidade de estabelecer critérios distintos para definir uma concepção de igualdade em cada uma delas. Fraser não acredita que as concepções de bem possam ser sempre discutidas de modo produtivo. 
Ela e Nicholson afirmam que há, sim, situações em que o conflito entre distintas concepções de bem pode ser insolúvel.

A permanência dessa distinção em Fraser e Nicholson as mantêm mais ligadas a Habermas do que Benhabib. O núcleo de sua crítica a Habermas está em outro ponto. Está na proposta de substituir a igualdade universal por uma igualdade "mais sociológica". Entretanto, uma concepção de igualdade, mesmo que mais sociológica, não parece ser compatível com o espaço em que o sujeito foucaultiano é construído. Tanto a "igualdade de participação política", quanto a igualdade pragmática, confrontam o pressuposto pós-moderno de que as relações humanas são sempre assimétricas. Tentar inserir o reconhecimento mútuo no argumento de Foucault e Butler é bastante problemático, pois a igualdade em ambos não é admitida nem mesmo no plano normativo. Afinal, as normas nada mais são do que um modo que naturalizar as exclusões e subordinações social e historicamente construídas. Em última análise, Fraser parece subestimar o desafio que o processo de constituição do sujeito em Foucault e Butler apresenta para teorias da justiça normativas. 


\section{À Guisa de Conclusão: $O$ fim da guerra de paradigmas está além de Fraser?}

O principal objetivo deste trabalho foi avaliar a tentativa de Fraser de pacificar a guerra de paradigmas na teoria feminista. Ela considera indispensável combinar o argumento de Butler na análise da subordinação feminina e a tese de Benhabib sobre uma concepção de autonomia que justifique a possibilidade de superação dessa subordinação. A análise do processo de subjetificação é crucial para entender a raiz da subordinação feminina, bem como suas intersecções com as discriminações raciais, de classe, etc. De outro lado, uma concepção de autonomia mais forte do que a de Butler é indispensável para a crítica social.

De fato, o processo de subjetificação de Foucault, incorporado por Butler, oferece recursos para a análise da subordinação da mulher. E isso, conforme dito no capítulo 2, não leva à morte do sujeito e de sua autonomia. Tanto em Foucault como em Butler, o sujeito sobrevive às relações de poder. Ele não é inteiramente determinado por elas.

A autonomia do sujeito, porém, é entendida de modo mais restrito. A impossibilidade de distanciamento das regras disciplinares circunscreve a ação humana à reprodução da regra. Seja a reprodução que confirma a subordinação, seja a que a questiona.

A autonomia em Butler e em Foucault não admite uma perspectiva externa ao poder. O poder está em toda parte. Para ambos, o distanciamento do poder é uma ilusão perniciosa, que promete uma liberdade irrealizável com o objetivo de esconder e justificar a subordinação.

No entanto, mesmo sem uma concepção forte de autonomia, Foucault e Butler reconhecem a possibilidade e a importância da crítica social, embora sua concepção de crítica seja modesta quanto à amplitude e quanto aos efeitos que pode gerar. A crítica pós-moderna é localizada. Não confia em princípios universais que funcionem como uma referência absoluta para dirigir a emancipação social em toda parte. Somente 
podemos avaliar a realidade que nos rodeia. Nós só criticamos as regras que nos constituíram. Os efeitos dessa crítica, por sua vez, tampouco estão respaldados em um princípio de igualdade. Ela não persegue um horizonte em que as assimetrias de poder sejam superadas. As relações de poder jamais são vencidas. Assim, sair da situação de subordinação implica ocupar a posição de subordinador.

Enfim, o resultado da crítica social não é a reconfiguração das desigualdades. Os grupos discriminados desafiam a regra para ocupar a posição de discriminadores. Essas reconfigurações são infinitas. As relações de poder são dinâmicas e, conforme o modo em que estejam organizadas, elas discriminarão um grupo social distinto.

Butler parte dessa concepção de crítica, mas incorpora noções psicanalíticas para explicar a motivação da vontade de subjetificação. Conforme foi dito no cap. 3, em Butler, a subordinação está relacionada ao nosso narcisimo primário, ou seja, ao nosso desejo básico de reconhecimento. O desejo de reconhecimento é tão poderoso que em nome dele nós nos submetemos a qualquer situação. Nós preferimos o reconhecimento social que nos oprime a não ter nenhum reconhecimento. Por isso, os indivíduos subordinados permanecem psiquicamente atrelados à sua própria subordinação.

A introdução da dimensão psicanalítica para explicar a subordinação é um elemento fundamental para entender a subordinação de gênero. $O$ exemplo das estudantes de Cornell, citado no capítulo 3, é apenas um entre os vários casos em que as mulheres cumprem as normas da feminilidade mesmo depois de a terem desmistificado racionalmente. A freqüente dificuldade que as mulheres têm de se libertarem de situações de violência doméstica é outro exemplo típico dessa situação.

A contribuição de Butler nessa questão é importante porque afasta a tese de que as mulheres "querem" a subordinação por comodismo ou porque esta é uma preferência legítima. Quando relaciona a vontade de subordinação a uma necessidade existencial de ter reconhecimento, Butler evita que se responsabilize o próprio oprimido por sua opressão.

Butler, enfim, deixa claro que mudar o modo como pensamos sobre as relações de gênero não é suficiente para transformá-las. A transformação dessas relações requer a transformação do desejo de subordinação em desejo de emancipação. Mas para 
desejarmos de modo diferente, não precisamos de identidades coletivas que funcionem com fonte alternativa de reconhecimento;

O poder definido em termos estratégicos, com em Butler, apresenta problemas para a criação de fontes de reconhecimento inclusivos. Afinal, da idéia de que o espaço social é inevitavelmente assimétrico decorre que os grupos minoritários que oferecem reconhecimentos alternativos também são excludentes. Por isso, para Butler, o reconhecimento é ao mesmo tempo um desejo humano inescapável e a causa de sua subordinação. Reconhecimento e subordinação, enfim, são armadilhas das quais não podemos nos liberar.

Entretanto, a capacidade de "dessubordinação", exige que nos liberemos de nossa vontade de reconhecimento social. Uma vontade que em Butler é tão vital quanto a sobrevivência física. Mas como nos liberar dessa vontade ¿ Amy Allen, com razão, afirma que em Butler a crítica social traz exigências muito altas. Ela requer que o sujeito se desvincule de sua vontade de existir, que se disponha a cometer um "suicídio social". Sem outra identidade coletiva na qual buscar reconhecimento, o indivíduo paga sozinho o preço de enfrentar a norma disciplinar.

Sem reconhecimento mútuo, Butler e Foucault não conseguem explicar porque resistimos à opressão. Esse é um dos principais embaraços que Butler precisa enfrentar para justificar a transformação social. Talvez por ter percebido isso, Butler se aventure em trilhas mais normativas em trabalhos posteriores ao the "Psychic Life of Power". No entanto, esse caminho é logo abandonado. Sua fidelidade ao processo de subjetificação de Foucault contém seus passos rumo ao reconhecimento mútuo.

Benhabib e Fraser oferecem exatamente o ingrediente que falta à concepção de crítica de Butler. Elas vislumbram a hipótese de o reconhecimento não se degenerar em destruição do outro ou de auto-destruição. Mas seus argumentos divergem em aspectos importantes.

Benhabib entende que a identidade emerge de relações intersubjetivas, em que o reconhecimento mútuo é condição para a construção da singularidade. Baseada em Arendt, ela argumenta que a identidade não exige nem a igualdade absoluta, excludente e totalitária, nem tampouco a diferença absoluta e sectária. 
A igualdade e a diferença são as duas condições de possibilidade do reconhecimento. A igualdade garante a possibilidade de compreensão recíproca, e a diferença gera a necessidade dessa compreensão. Assim, para ela, o reconhecimento recíproco é um imperativo da construção da identidade.

Isso não supõe, porém, um espaço social desprovido de poder. Benhabib segmenta os espaços de interação humana em concreto e generalizado. As desigualdades estão nas relações reais. No entanto, podemos superar essas desigualdades porque podemos de nos descentrar. $\mathrm{O}$ diálogo exige que sejamos capazes de nos afastar de nossos interesses subjetivos para nos colocar no lugar de nossos interlocutores.

Colocando-nos na posição do outro concreto, percebemos eventuais conflitos de interesse. Mas colocando-nos no lugar do outro generalizado, temos um critério para solucionar esses conflitos. Esses critérios não são individualistas, focados em nosso interesse particular. Tampouco requerem que o sujeito ceda ao interesse do outro ou do grupo. O "outro generalizado" distancia o sujeito de seu meio. É a posição que lhe permite enxergar além de seus interesses individuais e dos interesses de seus interlocutores imediatos. Mas quando nos distanciamos, não ficamos perdidos no espaço, pois o outro generalizado convive lado a lado com o "eu" e o outro concreto. Essa é a combinação que Benhabib elabora para conciliar o universal com o particular e o reconhecimento mútuo com as relações de poder.

Fraser, por sua vez, acredita que o modelo de Benhabib não dá a devida ênfase ao poder. Ela segue Butler quando afirma que as demandas sociais reunidas em torno de uma identidade não abarcam a pluralidade das reivindicações dos grupos oprimidos. Por isso, ela está de acordo com a idéia de que a identidade coletiva é excludente.

Mas, ao contrário de Butler, Fraser sustenta que é preciso admitir o reconhecimento mútuo a fim de que a crítica não se corrompa em mera reorganização das posições de oprimido e opressor. Para Fraser, a crítica feminista requer um ideal de igualdade de gênero combinado com uma análise realista da função que o poder cumpre na definição dos papéis sociais.

Conforme dito no cap. 3, Fraser propõe uma concepção de reconhecimento como status. Ela oferece uma alternativa às políticas de identidade, tanto àquelas que se 
baseiam em uma concepção reificada de cultura, quanto as que relacionam o reconhecimento à harmonia psíquica.

O reconhecimento como status implica políticas públicas universalistas que garantam a igualdade na participação política. O reconhecimento, portanto, não é conferido em nome do direito à diferença. Ele se justifica como condição para a igualdade entre os membros de uma sociedade. No entanto, o princípio da paridade de participação política não incide sobre questões de bem. Nesse caso, ela sustenta que não há um universal possível. Não há um critério abrangente para hieraquizá-las segundo sua validade moral. De outro lado, ela tampouco pretende deixar as questões de bem a salvo de avaliações. Sua fórmula para sair desse impasse foi construída em conjunto com Linda Nicholson. A "quase meta-narrativa" representa o elo entre o paradigma moderno e pós-moderno. É um tipo de narrativa que intermediária entre a fragmentação real e o universal ideal. Desse modo, Fraser evita que demandas particularistas de reconhecimento, que desafiam a igualdade, sejam legitimadas. Além de evitar também o perigo de impor concepções de bem para que os excluídos recuperem o auto-respeito.

Esse perigo, porém, é questionado por Benhabib. Ela discorda da reticência de Fraser em explorar a dimensão psíquica do reconhecimento. Na mesma linha de Jessica Benjamim, Benhabib procura relacionar as dimensões social e psíquica na formação do auto-respeito e da capacidade crítica do sujeito. Os danos causados pela falta de reconhecimento não podem ser resolvidos pela paridade de participação política. A igualdade de condições de falar e ser ouvido não é suficiente para que os sujeitos se disponham a falar. Os constrangimentos de participação política estão relacionados não apenas ao modo como a sociedade é organizada. Estão relacionados também à autolimitação que sujeitos com identidades depreciadas se impõem. Por isso, em Benhabib, o princípio universal da igualdade não pode deixar de lado as questões de bem, especialmente quando se trata da igualdade de gênero.

Conforme foi dito no capítulo 4, os valores estabelecem não apenas o modo como a sociedade posiciona cada sujeito e cada grupo social. Eles definem também como eles se auto-avaliam. Essa é uma conseqüência do processo de construção social do sujeito. Se não existe agente antes da ação, se não existe identidade anterior à interação intersubjetiva, então nosso self será constituído pelos valores de nossa comunidade. Mas mesmos esses valores não são eternamente atrelados à nossa 
identidade. Quando entramos na rede de interlocução, inauguramos o processo de constante ressignificação de nossa história. Cada vez que a narramos, revemos tanto as concepções de justiça, quanto as concepções de bem de nosso meio.

De certo modo, esse argumento de Benhabib a aproxima mais de Butler do que de Fraser. Aqui Benhabib compartilha com Butler a preocupação em explorar a "vida psíquica do poder", o que Fraser não faz. No entanto, seu modo de lidar com essa questão é bem diferente. Benhabib estende a aplicação do universalismo procedimental de Habermas a questões de bem. Assim, ela se afasta tanto de Butler como de Fraser.

Enfim, na tentativa de conciliar o paradigma moderno e o pós-moderno, Fraser parte do sujeito foucaultiano e, assim como Butler, sustenta que a emancipação feminina exige a desconstrução da identidade de gênero. No entanto, ela acredita que é necessário reconstruir uma concepção de igualdade que cumpra a função propositiva da crítica social. Em sua concepção de igualdade encontram-se argumentos modernos e pós-modernos combinados.

$\mathrm{Na}$ concepção foucaultiana de sujeito, ela identifica "insights empíricos", ou seja, identifica um forte potencial para descrever a origem das desigualdades. Mas para Fraser, Foucault e Butler não oferecem "insights normativos". Por isso, eles precisam ser complementados pela normatividade não fundacionista de Benhabib.

Posta desse modo, essa soma parece simples. Entretanto, ela parece minimizar a profundidade do desafio teórico que Foucault e Butler apresentam para a concepção moderna de autonomia, crítica e validade. O sujeito produzido pelo poder, embora não seja determinado pelo meio, é dotado de uma autonomia muito mais limitada. A impossibilidade de adotar a perspectiva externa, de escapar da regra disciplinar, restringe o espaço e a finalidade da crítica social.

O espaço social necessariamente assimétrico não pode ser combinado com uma concepção de autonomia que dê conta da tarefa propositiva da teoria crítica. Butler e Foucault, no entanto, podem assumir esse compromisso porque, ao contrário de Fraser, não têm pretensão de criar concepções de igualdade universais, nem tampouco abrangentes como as "quase meta-narrativas" de Fraser. 
Fraser, com razão, nota uma inconsistência entre a militância de Butler contra a exclusão no feminismo e sua resistência em admitir um critério para inclusão social. Mas essa inconsistência não é facilmente superável. Sua concepção de reconhecimento exprime essa dificuldade.

Amy Allen segue as pegadas de Fraser até esse ponto. Mas afirma que a integração entre a autonomia e o poder na teoria feminista não pode ser feita por uma simples soma entre desconstrução da identidade e reconstrução da igualdade, como quer Fraser. Em seu livro "The politics of ourselves" (2008), ela se propõe a realizar o projeto de Fraser reunindo a dimensão psíquica, social e intersubjetiva da constituição do self à idéia de que poder está sempre presente nas relações sociais.

Sua tese, porém, supõe algumas modificações em cada um dos pólos desse debate. Os argumentos de Butler e Benhabib não estão prontos para serem integrados. Para isso, é preciso fazer com que Butler ceda à intersubjetividade e que Benhabib conceda um espaço maior ao poder ${ }^{313}$.

Seguindo Fraser e Benhabib, Allen afirma que a teoria crítica de Habermas tem muito a oferecer ao feminismo. Sua forma de justificação e normatividade não essencialista e não fundacionalista contribui para contextualizar categorias como a família, cujo papel na construção da identidade de gênero é crucial. Além disso, a ênfase na intersubjetividade e na autonomia funcionam para dotar o feminismo de capacidade transformadora. No entanto, ainda seguindo Fraser, Allen afirma que a intersujetividade não faz justiça ao papel que o poder cumpre no processo de constituição da identidade e da autonomia do sujeito. Por isso, conclui Allen, Fraser está correta em buscar um modo de conciliar Butler e Benhabib. No entanto, para ela, Fraser não explorou todas as dificuldades que essa tarefa apresenta ${ }^{314}$.

Para realizar o projeto de Fraser, diz Allen, é preciso primeiramente admitir a impureza da autonomia e da razão prática tal como Butler e Focault fazem. Isso significa abrir mão de desvencilhar poder de validade. Como o interesse da crítica feminista está em diagnosticar e superar as desigualdades, ela deve buscar respostas tanto para como a subjetificação afeta nossa autonomia, quanto para como afeta nossos

\footnotetext{
${ }^{313}$ Allen, Amy. The politics of ourselves, p. 8

${ }^{314}$ Idem, p. 8.
} 
impulsos de subordinação. Deve, enfim, estar voltada não apenas à capacidade de reflexão crítica, mas também à possibilidade de reorganizar o desejo, de modo a tornálo um impulso de emancipação, e não de subordinação.

Allen afirma que a transformação do desejo de se subordinar exige o reconhecimento mútuo. Mas ela também diz que não há nenhum espaço em que o poder não incida. Mas a reciprocidade não supõe simetria ¿ E a simetria não supõe espaços sociais livres de poder;

Para lidar com esse problema, Allen propõe outra interpretação da idéia de que não há espaço sem poder $^{315}$. Cito:

"Nós podemos abdicar da idéia da onipresença e reter a idéia de que não há espaço sem poder no sentido de que não há forma de vida social reconhecidamente humana da qual o poder tenha sido totalmente eliminado. (...) Seguindo Benjamim, nós podemos entender o reconhecimento mútuo não como um estado possível das relações sociais da qual as relações de poder tenham sido permanentemente e completamente expugnadas, mas como uma permanente embora temporária possibilidade no desenvolvimento dinâmico dos relacionamentos humanos. $O$ reconhecimento mútuo, portanto, pode ser pensado como um ideal que é imanente à vida social, é o ponto de apoio na prática social para a crítica normativa” (grifos meus").

O que é "uma permanente embora temporária possibilidade dos relacionamentos humanos”; O que significa dizer que "não há interação humana sem poder, mas que o poder não é onipresente" ¿

A interpretação de Allen da concepção de poder soa confusa. Na tentativa de conciliar a inevitabilidade da assimetria de poder ao reconhecimento mútuo, Allen formula idéias obscuras. Quando diz que segue a concepção de reconhecimento mútuo de Benjamim, porém, ela nos dá uma pista sobre seu ponto de apoio. Voltemos, então, a Benjamim.

\footnotetext{
315 " one could drop the omnipresence claim but retain the idea that there is no outside power in the sense of no possible form of recognizable human social life from which power has been wholly eliminated. Following Benjamim, we could understand mutual recognition not as a possible state of social relations from which power relations have been permanently and completely exounged but as a permanent thought temporally fleeting possibility within dynamically unfolding human relationships. Mutual recognition, then, can be thought of as an ideal that is immanent to social life; it provides a foothold within social practice for normative critique". Idem, p. 179
} 
Em Jessica Benjamim, o reconhecimento combina o caráter destrutivo e construtivo do processo de subjetificação. Para nos auto-afirmar, precisamos negar a diferença; mas para sermos reconhecidos, precisamos admitir o papel construtivo que o outro cumpre na construção de nossa singularidade. A idéia que está por trás da dinâmica de reconhecimento de Benjamim é a relação entre igualdade e diferença de Hannah Arendt.

Amy Allen parece ver na tese de Benjamim uma combinação bem sucedida entre sujeito moderno e pós-moderno. A idéia de que o reconhecimento reúne diferença e igualdade sugere um modo de conciliar poder com intersubjetividade. Para Allen, Bejamim oferece também um modo de agrupar a dimensão psíquica com a social, indicando um caminho intermediário entre Butler, Benhabib e Fraser.

No entanto, reconciliar igualdade e diferença não implica uma adesão ao sujeito pós-moderno. A oposição de Benjamim às identidades coletivas revela de fato um certo alinhamento com Butler. No entanto, parece um exagero dizer que Benjamim tenha obtido o meio termo entre o self moderno e o pós-moderno.

Contextualizar o sujeito e reconhecer as assimetrias de poder nos espaços sociais não supõe necessariamente o sujeito foucaultiano. O self narrativo de Benhabib é um exemplo disso. O sujeito em Benhabib não é abstrato como o sujeito moderno tradicional. Ele é construído em redes de interlocução que estão repletas de desigualdades. No entanto, Benhabib localiza no diálogo a possibilidade imanente de as desigualdades serem superadas. É essa possibilidade que lhe permite conceber o reconhecimento mútuo.

Em Benjamim, o argumento segue na mesma linha. No entanto, ela adere à crítica de Butler à generalidade. Ela teme que a identidade reduza a subjetividade a uma categoria unívoca e estável. Enfim, Benjamim admite a possibilidade de constituição intersubjetiva do self, mas não da identidade. Entretanto, se o self é constituído num processo de reconhecimento mútuo que se desenvolve tanto no plano social quanto psíquico, isso significa que ela admite a intersubjetividade na esfera social. Não parece, assim, haver nenhuma razão para ela distinguir o self da identidade.

Conforme diz Benhabib, a teoria de Benjamim não é apenas compatível com a identidade. Sua concepção de reconhecimento mútuo exige a fusão entre self e 
identidade. A inclusão do outro, sem a sua assimilação, o principal tema de Benjamim, supõe a síntese das narrativas da rede de interlocução. Alguma capacidade de generalização é necessária para admitir a intersubjetividade no processo de construção do sujeito. Mas aqui se trata de uma generalização provisória, que é continuamente desafiada à medida que novas narrativas vão sendo preparadas.

A harmonia entre o sujeito moderno e pós-moderno requer muito mais do que alinhar igualdade e diferença em uma mesma teoria. A teoria de Benhabib sugere que a contextualização e a provisoriedade da identidade não implica ceder ao sujeito pósmoderno. Embora ela tenha caminhado para uma posição mais próxima da de Butler ao longo do tempo, a fronteira entre ambas continua bem demarcada. O limite que as separa está justamente na concepção de sujeito que cada uma adota. Benjamim, nesse aspecto, revela-se mais próxima de Benhabib do que Butler, uma vez que a categoria inclusão é central em seu argumento.

A tentativa de Allen de realizar o projeto de Fraser com base no reconhecimento intersubjetivo de Bejamim é problemática. Allen, de fato, dá alguns passos importantes quando incorpora a dimensão psíquica da subordinação à sua tese. No entanto, ao voltar-se a Benjamim para fazer isso, ela se aproxima muito do argumento de Benhabib, que não faz concessões ao pós-moderno. Ela faz, sim, concessões à contextualização. Mas seu self narrativo ainda é bastante diferente do self performativo.

Em suma, nem Fraser e nem Allen são bem sucedidas em resolver a tensão entre Butler e Benhabib. Se há uma solução para a guerra de paradigmas na teoria feminista, ela ainda não foi encontrada. Mas será mesmo preciso encontrar esse meio termo para justificar as identidades coletivas e a capacidade transformadora dos movimentos sociaisi.

A importância desse debate está diretamente relacionada à representatividade do movimento feminista, aos reflexos que as assimetrias de poder nas interações reais produzem na definição da agenda do movimento. Está também ligada às implicações que a contextualização do sujeito traz para sua a capacidade crítica e de seu grupo social. A extensão e a profundidade da transformação social baseiam-se em um modelo de construção da subjetividade. No entanto, a dificuldade de Fraser e de Allen em 
aproveitar o melhor do paradigma moderno e do pós moderno sugere que essa não deve ser a rota da crítica feminista.

A contribuição de Butler é, sem dúvida, crucial para entender a exclusão no movimento. A repercussão de sua obra foi tão impactante justamente porque elaborou teoricamente a tensão crescente no feminismo por todo mundo, inclusive no Brasil. No entanto, seus argumentos levantam muitos problemas para a ação coletiva. É muito difícil encontrar em seu pensamento um modo de justificar a mobilização social em torno de uma causa comum.

Enfim, Butler tem o mérito de ter levantado e refinado o debate sobre a exclusão do feminismo. Foi ela que incluiu esse tema definitivamente na pauta da teoria feminista. Mesmo teóricas mais afinadas com teorias normativas tiveram de ceder à agenda trazida por Butler. O debate que travou com Benhabib e Fraser mostra que, depois de "Gender Trouble", a teoria social, política e psicanalítica feminista não pode ignorar esse problema.

No entanto, estender o pensamento de Butler até o ponto de submetê-lo ao normativismo de Benhabib não parece razoável. Tampouco isso parece ser necessário. A maior contribuição de Benhabib nesse debate é a elaboração de um modo alternativo de conceber o processo de construção do sujeito que não cede inteiramente nem a pressupostos modernos nem a pós-modernos. Mas ela faz isso sem a pretensão de combinar paradigmas. Sua concepção de sujeito é assumidamente moderna. O processo de construção do self narrativo é contextualizado e provisório, assim como em Butler, mas ela retém uma concepção de autonomia muito mais forte do que o self performativo de Butler permite.

Mesmo admitindo a dificuldade ou talvez até a impossibilidade da empreitada de Fraser, isso não significa ter de escolher entre diagnosticar e superar as desigualdades de gênero. A teoria de Benhabib traz a promessa de equilibrá-los. Até então, as críticas que Fraser, Butler e Allen lhe fizeram não parecem convincentes. O self narrativo de Benhabib tem maior potencial para aliviar a tensão entre poder e autonomia.

Enfim, ainda não é preciso ir além de Fraser. O melhor argumento entre as autoras discutidas neste trabalho está aquém da árdua tarefa de Fraser. Repensar as 
categorias da modernidade com ferramentas teóricas modernas parece ainda ser o caminho mais promissor para a crítica feminista. 


\section{BIBLIOGRAFIA}

Alcoff, Linda Martfn. "Feminist Politics and Foucault: The Limits to a Collaborationl' In Crises in Continental Philosophy, ed. Arlene Dallery and Charles Scott. Albany: SUNY Press, Lggo.

Allen, Amy.. "Power, Subjectivity, and Agency: Between Arendt and Foucaultl' International Journal of Philosophical Studies ro:z (May zooz): :ryl-49.

and "Reconstruction or Deconstruction? A Reply to |ohanna Meehan ' Philosophy Social Criticism 263 (May zooo)

Anderson, Aman da. The Way We Argue Now: A Study in the Cultures of Theory. Princeton, NJ: Princeton University Press, zoo6.

Arendt, Hannah. The Human Condition. Chicago: University of Chicago Press, 1958.

--. "W'hat is Freedom?" In Between Past and Future: Eight Exercises in Political Thought. New York: Penguin Books,

Bartky, Sandra. Femininity and Domination: Studies in the Phenomenology of Oppression.

New York: Routledge, 1990.

Benhabib, Seyla. The Claims of Culture: Equality and Diversity in the Global Era. Princeton, N): Princeton University Press, $200 z$.

Critique, Norm, and Utopia: A Study of the Foundations of Critical Theory. NewYork: Columbia University Press,

The Reluctant Modernism of Hannah Arendt London: Sage, ry96.

Constellationl' Signs: "Sexual Difference and Collective ldentities: The New Global

Situating the Self Gender Community, and Postmodernism in Contemporary Ethics.New York: Routledge, 1992.

Benhabib, Seyla, Iudith Butler, Drucilla Cornell, and Nancy Fraser. Feminist Contentions:

A Philosophical Exchange. New York: Routledge, L9gs. 
Benjamin, Jessica. The Bonds of Love: Psychoanalysis, Feminism, and the Problem of Domination. New York: Pantheon, 1988.

Like Subjects, Love Objects: Essays on Recognition and Sexual Diference. New Haven,CT: Yale University Press.

The Shadow of the Other: Intersubjectivity and Gender in Psychoanalysis. NewYork: Routledge, 1998.

Theoryl'In Benjamin, "The Shadow of the Other Subject: Intersubjectivity and Feminist

Biebricher, Thomas. "Habermas, Foucault, and Nietzsche: A Double Misunderstandingl'Foucault Studies g (November zoo5)

Bohman, |ames. "Participating in Ehlightenment: Habermas's Cognitivist Interpretation of Democracyl' In l(nowledge and Politics: Case Studies in the Relationship

Between Epistemology and Political Philosophy, ed.

Marcelo Dascal and Ora Gruengard.Boulder, CO: Westview Press, 1989.

Bordo, Susan. Unbearable Weight: Feminism, Western Culture, and the Body. Tenth anniversary

ed. Berkeley and Los Angeles: University of California Press, zooz.

Brown, W.endy. States of Injury: Power and Freedom in Late Modernify. Princeton, NJ: Princeton University Press,

Brumberg, Joan Jacobs. The Body Project: An Intimate History of American Girls. New York: Vintage.

Buckner, )anine and Robyn Fivush. "Gender and Self in Children's Autobiographical Narratives!' Applied Cognitive Psychology

Butler, Judith. "Bodies and Power Revisitedl' In Feminism and the Final Foucault, ed. Dianna

Taylor and 1(aren Vintges. Champaign: University of Illinois Press, 2004.

Routledge,:.ggg.

Bodies That Matter: On the Discursive Limits of "Sex'! New York:

Universality: Contemporary

Dialogues on the Left, ed. Judith Butler, Ernesto Laclau, and Slavo) Zizek. London: 2000.

York: Routledge, Gender Trouble: Feminism and the Subversion of ldenfify. New 1990. 
Press, 200;

Giving an Account of Onesefi New York: Fordham University

"Longing for Recognitioni' In Butler, Llndoing Gend,er.

The Psychic Life of Power: Theories in Subjection. Stanford, CA: Stanford University Press, $\operatorname{tgg} 7$.

Subjects of Desire: Hegelian Reflections in Twentieth Century

France. New york:Columbia University Press, Undoing Gender. New York: Routledge, 2004.

"Violence, Mourning, Politicsl' In Precarious Life: The Powers of Mourning andViolence. London: Verso, 2oo4,

Cooke, Maeve. "Habermas, Autonomy, and the Identity of the Selfl' Philosophy and Social Criticism

"Habermas, Feminism, and the Question of Autonomyi' In Habermas:

A CriticalReader, ed. Peter Dews. Oxford: BlackwellLanguage and Reason: A Study of Habermns's Pragmatics, Cambridge, MA: MIT

Press, L994.

Theory.

Re-presenting the Good Society: Philosophical Issues in Critical Social

Cambridge, MA: MIT Press, zoo6.

"Moderniry, Self-Consciousness, and the Scope of Philosophy: )urgen Habermasand Dieter Henrich in Debatel' In The Limits of Disenchantment: Essays on ContemporaryEuropean Philosopky. New York: Verso, Lg9s.

Philosophy s, (Spring: 37-4L)

"The Return of Subjectivity in the Late Foucault.' Radical

Dreyfus, Hubert and Paul Rabinow. "'What is Maturity? Habermas and Foucault on 'What is Enlightenment?"' In Foucault: A Critical Reader, ed. David Hoy.

London:Blackwell, 1986.

Fausto-Sterling, Anne. Myths of Gender: Biological Theories About Women and Men. $\mathrm{zd}$

ed. New York: Basic Books, 1gg2.

Fivush, Robyn. "The Stories 'We Tell: How Language Shapes Autobiographyl' Applied Cognitive Psychology rz (rqg8) : +89-Bz.

Flynn, Thomas. A Poststructuralist Mapping of History. Vol. z of Sartre, Fotrcault, and Historical Reason. Chicago: University of Chicago Press, 2005.

Foucault, M. Afterword: The Subject and Powerl' In Michel Foucault: Beyond Structuralism and Hermeneutics, zd ed., ed. Hubert Dreyfus and Paul Rabinow. Chicago: University 
of Chicago Press, 1983.

Trans. A. M. Sheridan-

The Archaeologlr of Knowledge and the Discourse on Language.

Smith. New York: Pantheon, LgZz.

"The Art of Telling the Truthl' In 1(elly, Critique and Power.

Discipline and Punish: The Birth of the Prison. Trans. Alan

Sheridan. New York:Pantheon.

$\mathrm{a} \$$

Dits et 6 crits.6 vols. Paris: Vrin, Lgg4. ii\#

"The Ethics of Concern for the Self as a Practice of Freedom !' In Ethics, Subjectiv- 'iii'| ity, and Truth. Vol. $r$ of The Essential Works of Michel Foucault, ed. Paul Rabinow. ir New York: The New Press,

Foucault, ed. ,t',

"Governmentalityl' In Power. Vol. g of The Essential Works of Michet

"Polemics, Politics, and Problematizations: An

Interviewl'In The Foucault Reader,ed. Paul Rabinow. New York: Pantheon, 1984.

'A Preface to Transgressionl' In Language, Counter-Memory, Practice:

Selected

Essays and Interviews by Michel Foucault, ed. D. F. Bouchard. Ithaca, NY' Cornell University Press, tgZZ.

"Que'est-ce que la critique?/Critique et Aufkldru ng, Bulletin de la socidtd frangaisede philosophie .

"The Return of Moralityl' In Michel Foucault: Politics, Philosophy, Culture, ed.Lawrence 1(ritzman. New York: Routledge, r9g8.

"W'hat Is Enlightenment?" In Ethics, Subjectivity, and Truth. Vol. r of. The EssentialWorks of Michel Foucault, ed. Paul Rabinow. New York: The New Press

Fraser, Nancy. "Foucault on Modern Power: Empirical Insights and Normative Confusionsl'

In Fraser, Unruly Practices. Power, Discourse and Gender in Contemporary Social Theory.

Minneapolis: University of Minnesota Press, 1989.

"'What's Critical About Critical Theory? The Case of Habermas and

Genderl' InFraser, Unruly Practices, 
Gilligan, Carol. In a Dffirent Voice. Cambridge, MA: Harvard University Press, 1982.

Golombok, Susan and Robyn Fivush. Gender Development, Cambridge: Cambridge University Press, 1994.

Habermas, Jurgen. Between Facts and Norms: Contributions to a Discourse Theory of Law and Democracy. Trans. \$/illiam Rehg. Cambridge, MA: MIT Press, 1996.

Lifeworld and System: A Critique of Functionalist Reason. Vol. 2of

The Theory ofCommunicative Action, trans. Thomas McCarthy. Boston: Beacon press, Lgg7. --. Moral Consciousness and Communicative Action Trans. Christian Lenhardt and

shierry weber Nicholsen. cambridge, MA: MIT press, Lg9o.

Consciousness

"Moral Consciousness and Communicative Actioni' In Haberma s, Moral

and Communicative Action.

Evolution of

"Moral Development and Ego Identityl' In Communication and the

'A Replyl' In Communicative Action: Essays on Habermas's The Theo ry ofCommunicativeAction, ed. Axel Honneth and Hans Ioas. Cambridge, MA: MIT press, Lg9t.

Hartsock, Nancy. "Foucault on Power: A Theory for Women?" In

Feminism/postmodernism,

ed. Linda Nicholson. New york: Routledg e, 1990

Heath, /oseph. "Ideology, Irrationality, and Collectively Self-defeating Behaviorl'

Constellations

zB (zooo):

Hqy,David..,Foucault: Modern or Postmodern?" InAfter Foucault:

Humanistic lfuowled,ge, Postmod,ern Challenges, ed. |onathan Arac. New Brunswick, N): Rutgers UniversityPress, r988.

cault: A Critical Read,er,ed. David Hoy. London: Blackwell, 1986'

Laclau, Ernesto. "Identity and Hegemonyi'

Contemporary Dialogues on the Left, ed'

McCarthy, Thomas. The Critical Theory of lilrgen Habermas' Cambridge' MA: MIT Press, 1978.Critical Theory. Cambridge, MA: MIT Press' r99L'

McNay, Lois. Foucault and. Feminism: Powen Gend'er and the Self. Cambridge: Polity Press, L992.

"Communicative

Having It Both Ways: The Incompatibility of Narrative Identity and

Ethics in Feminist Thou ght!' Theory, culture, and society zo:6 (zoo3): 
Meehan, Johanna. 'Autonomy, Recognition, and Respect: Habermas, Benjamin' and Honneth i, In Feminists Read Habermas: Gendering the Subject of Discourse' New York: Routledge,

Pitkin, Hanna Fenichel. The Attack of the Blob: Hannah Arendt's Concept of the Social. Chicago: University of Chicago Press, 1998.

Weir, Allison. Sacrfficial Logics: Feminist Theory and the Critique of ldentity. New York:Routledge, 1996.

Wellmer, Albrecht . The Persistence of Modernity: Essays on Aesthetics, Ethics, and Postmodernism.Cambridge, MA: MIT Press.

Zerilli, Linda. "Doing Without I(nowing: Feminisms Politics of the Ordi naryl, political Theory z6 UggS): 435-58.Feminism and the Abyss of Freedom, Chicaso: University of Chicago press, 2002. 